\title{
ANALYSIS OF RESIDENTIAL USE OF WATER IN THE DENVER METROPOLITAN AREA, COLORADO, 1980-87
}

by David W. Litke, U.S. Geological Survey, and

LeRoy F. Kauffman, Denver Water Department

U.S. GEOLOGICAL SURVEY

Water-Resources Investigations Report 92-4030

Prepared in cooperation with the

CITY AND COUNTY OF DENVER,

BOARD OF WATER COMMISSIONERS

Denver, Colorado

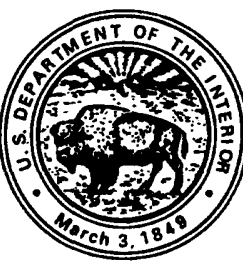




\section{U.S. DEPARTMENT OF THE INTERIOR \\ BRUCE BABBITT, Secretary \\ U.S. GEOLOGICAL SURVEY \\ Dallas L. Peck, Director}

For additional information write to:

District Chief

U.S. Geological Survey

Box 25046, Mail Stop 415

Federal Center

Denver, Colorado 80225
Copies of this report can be purchased from:

U.S. Geological Survey

Books and Open-File Reports Section

Box 25425

Federal Center

Denver, Colorado 80225 


\section{CONTENTS}

Page

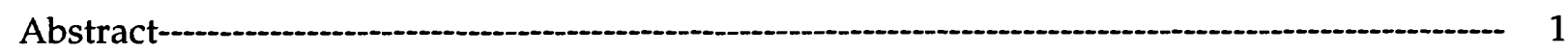

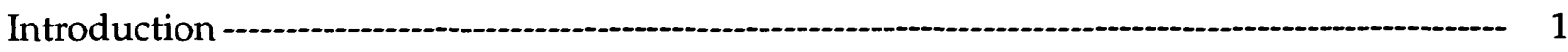

Residential water use -

Water-use cycle - -

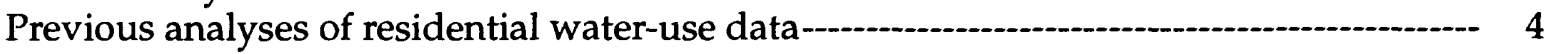

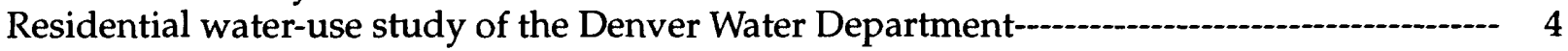

History of the study -

Collection of data -

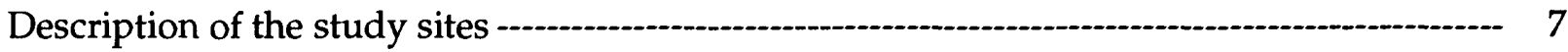

Water use at study sites--

Analysis of data -

Average water use - - 30

Base water use -

Seasonal water use-- 33

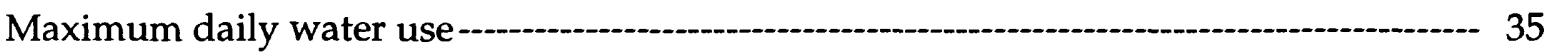

Maximum hourly water use--.--.-- 37

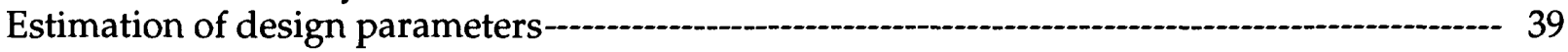

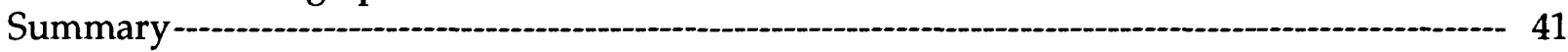

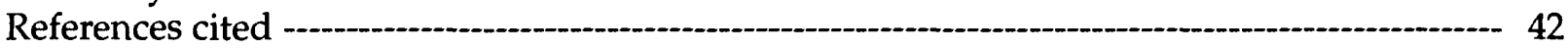

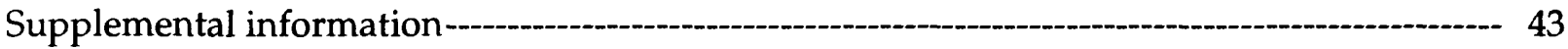

Site E48 -.---.-- 44

Site G11 - -

Site G52 ---

Site H29--.-- 47

Site M47 --- 48

Site N3J -..-1- 49

Site N5T - -

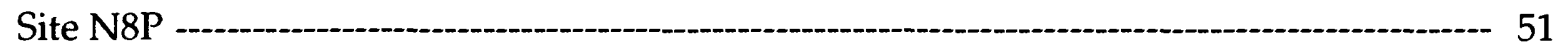

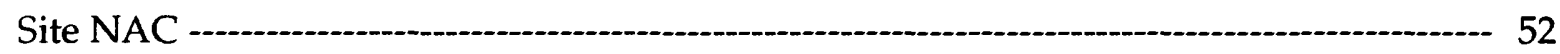

Site NBW -

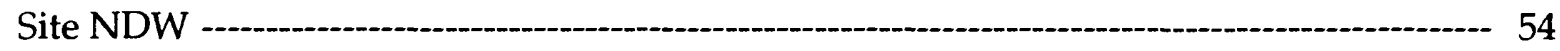

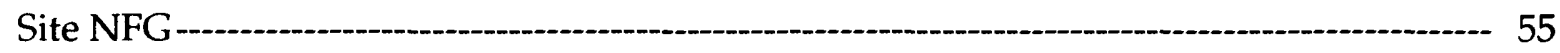

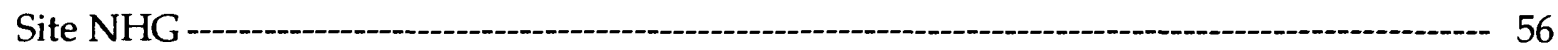

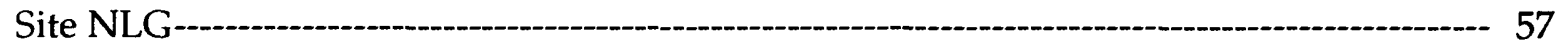

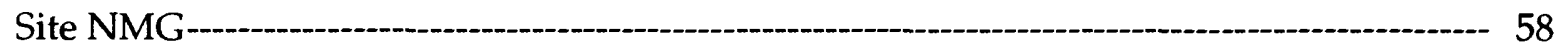

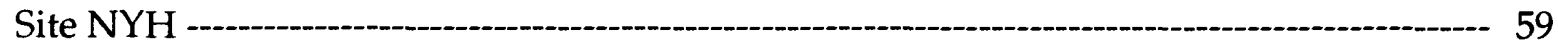

Description of data files on disk- 60

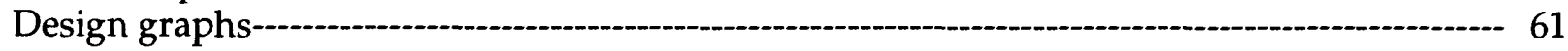

A.--Base water use, metered sites --o-n 62

B.--Seasonal water use, metered sites -

C.--Seasonal water use, flat-rate sites - -

D.--Seasonal water use using Blaney-Criddle water requirement, in inches (B), metered sites: predicted value-- 65

E.--Seasonal water use using Blaney-Criddle water requirement, in inches (B), metered

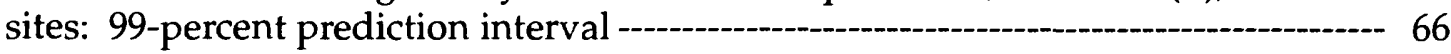

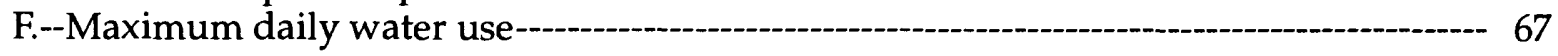




\section{CONTENTS--Continued}

G.--Maximum hourly water use using number of housing units $(\mathrm{n})$ : predicted value --- 68

H.--Maximum hourly water use using number of housing units (n): 99-percent prediction interva

\section{FIGURES}

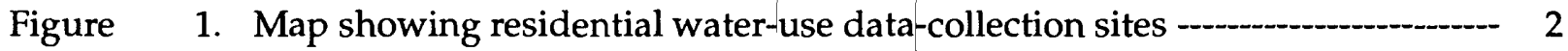

2. Photograph of typical water-meter site and recorder installation-_-_-_-_-.-- 7

3-25. Graphs showing:

3. Weekly average water use at sites NHG and E48 and daily total precipitation and daily maximum air temperature at the Denver Airport weather station, 1987

4. Hourly water use at site E48, for winter and summer, June 1986-

December 1987

5. Hourly water use at site G11, for winter and summer, July 1986December 1987

6. Hourly water use at site G52, for winter and summer, June 1986-

December 1987

7. Hourly water use at site H29, for winter and summer, June 1986-

December 1987

8. Hourly water use at site M47, for winter and summer, June 1986December 1987

9. Hourly water use at site N3J, for winter and summer, June 1986December 1987

10. Hourly water use at site N5T, for winter and summer, June 1986-

December 1987

11. Hourly water use at site N8P, for winter and summer, June 1986December 1987

12. Hourly water use at site NAC, for winter and summer, January 1987December 1987 -

13. Hourly water use at site NBW, for winter and summer, July 1986December 1987

14. Hourly water use at site NDW, for winter and summer, June 1986December 1987 -

15. Hourly water use at site NFG, for winter and summer, August 1986December 1987

16. Hourly water use at site NHG, for winter and summer, September 1986December 1987-

17. Hourly water use at site NLG, for winter and summer, August 1986December 1987-

18. Hourly water use at site NMG, for winter and summer, June 1986December 1987

19. Hourly water use at site NYH, for winter and summer, January 1987December 1987 


\section{FIGURES--Continued}

20. Relation of weekly average water use to weekly average maximum air temperature for site NHG, 1980-87 --------------------------------- 31

21. Relation of base water use to persons per housing unit ----------------- 32

22. Relation of seasonal water use to lot size----

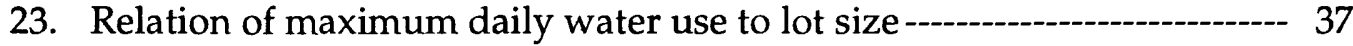

24. Relation of maximum hourly water use to lot size-------------------------- 38

25. Quantiles for Blaney-Criddle lawn-watering requirement, 1965-87 ------ 41

\section{TABLES}

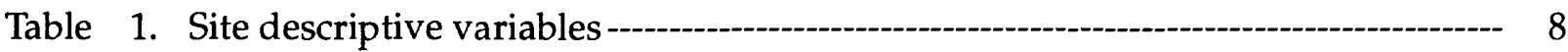

2. Summary statistics for water use at study sites------------------------------------- 11

3. Lawn-watering-season weather statistics, Denver Airport weather station-------- 36

4. Example of residential water-use design calculations ---o--------------------------- 40

\section{CONVERSION FACTORS}

\section{Multiply}

acre

foot

gallon

gallon per day

gallon per minute

gallon per person per day

gallon per housing unit per day

(GUD)

inch

pound per square inch

square foot
By

0.4047

0.3048

0.00379

0.00379

0.00379

0.00379

0.00379

0.0254

6.895

0.0929
To obtain

hectare

meter

cubic meter

cubic meter per day

cubic meter per minute

cubic meter per person

per day

cubic meter per

housing unit per day

meter

kilopascals

square meter

Temperature can be converted from degree Fahrenheit $\left({ }^{\circ} \mathrm{F}\right)$ to degree Celsius $\left({ }^{\circ} \mathrm{C}\right)$ by using the following equation:

$$
{ }^{\circ} \mathrm{C}=5 / 9\left({ }^{\circ} \mathrm{F}-32\right)
$$




\title{
ANALYSIS OF RESIDENTIAL USE OF WATER IN THE DENVER METROPOLITAN AREA, COLORADO, 1980-87
}

\author{
By David W. Liłke and LeRoy F. Kauffman
}

\section{ABSTRACT}

Residential water-use data for 16 study sites in the City and County of Denver are described and analyzed. The dataset, collected by personnel of the City and County of Denver (Denver Water Department) as part of its Residential Water Use Study, consists of weekly water-use data for 1980-87 and hourly water-use data during 1986 and 1987.

The data were separated into temperature-independent (base) water use and temperature-dependent (seasonal) water use. Average base water use ranged from 137 to 307 gallons per housing unit per day (GUD). Base water use as a percentage of total water use ranged from 28 to 85 percent. For metered sites, base water use was linearly related to persons per household. Average seasonal water use ranged from 25 to 575 GUD. Linear relations were developed for estimating seasonal water use based on lot size and billing type; flat-rate sites used more water relative to lot size than did metered sites. Annual variability in average water use was relatively small; therefore, relations developed from the study dataset for estimating seasonal water use based on lot size probably are applicable over the long term.

Maximum daily water use ranged from 239 GUD (1.51 times average use) to 3,603 GUD (6.29 times average use). Maximum daily water use can be estimated using a linear relation with lot size. Maximum hourly water use ranged from 412 GUD (2.61 times average daily use) to 8,191 GUD (9.75 times average daily use). Maximum hourly water use can be estimated using a regression equation containing lot size and number of housing units as explanatory variables.

\section{INTRODUCTION}

Management of public water-supply systems requires quantification of water supply and water use. Commonly, the largest use sector of public-supply systems is residential water use. An understanding of the magnitude and variability of residential water use is useful for designing water-supply systems. For example, average water use can be used as a guideline for sizing water-supply reservoirs; maximum daily water use can be used for sizing drinking-water treatment plant capacity; and maximum hourly water use can be used for sizing water transmission lines.

A dataset of residential water use has been compiled by personnel of the City and County of Denver, Board of Water Commissioners (hereinafter called the Denver Water Department) as part of its Residential Water-Use Study (RWUS). In 1989, the Denver Water Department and the U.S. Geological Survey began a cooperative study to analyze this dataset. This dataset contains data collected from 16 residential study sites within the City and County of Denver (fig. 1). For most sites, weekly data are available for calendar years 1980-87, and hourly data are available for June 1986 through December 1987. The "Supplemental Site Information" section of this report includes more detailed information on studysite locations and periods of data. 

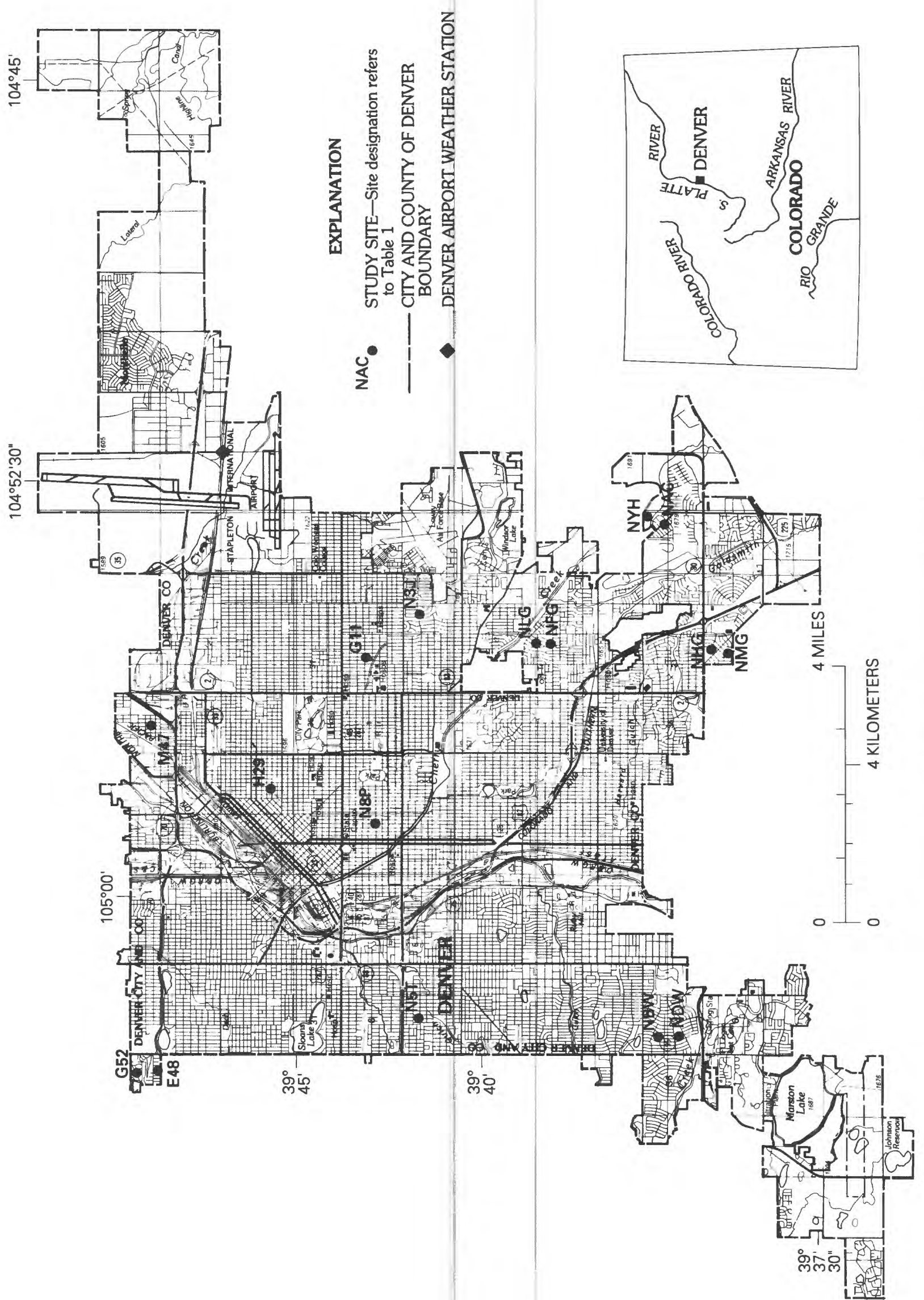

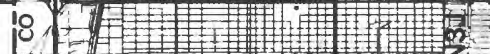

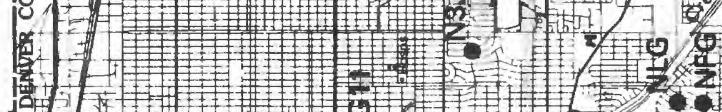


The purpose of this report to: (1) describe the RWUS; (2) describe residential water use in Denver as reflected by the RWUS dataset; and (3) analyze the RWUS dataset to provide equations for estimating three important design parameters: average water use, maximum daily water use, and maximum hourly water use.

\section{RESIDENTIAL WATER USE}

Residential water use consists of water used at single-family and multifamily residences. It includes inside water use for clothes washing, bathing, toilet flushing, and other inside activities; and outside water use for lawn and garden irrigation, car washing, and other outside activities. Water-use rates, measured in gallons per day, need to be standardized so that comparisons between sites can be made. Data may be standardized by using number of taps, number of persons, or, as was done in this study, number of housing units; hence, data are reported herein in gallons per housing unit per day (GUD). A housing unit is defined according to the U.S. Census definition as a house, apartment, room or group of rooms occupied as a single living quarters; housing units in the study sites consist primarily of houses, condominiums, townhomes, duplexes, and apartments. Water-use rates for intervals of time smaller or larger than a day also are commonly reported in gallons per housing unit per day so that there is a common unit for comparison; for example, annual water use is not reported in gallons per housing unit per year, but in gallons per housing unit per day.

\section{Water-use Cycle}

Residential water use can be viewed as a cycle, beginning with the source of water and ending with the disposal of the water. Residential water users obtain water from publicsupply systems (publicly supplied users) or from their own wells (self-supplied users). Ninety-three percent of the people in Colorado obtained their water from public-supply systems during 1985; virtually the entire population of Denver County obtained their water from the Denver Water Department, which delivered about 29 billion gallons of water to these residential users during 1985 (Litke and Appel, 1989, p. 118). Self-supplied residential water users generally use less water per housing unit than do public-supplied residential water users; this study focuses exclusively on public-supplied residential water users.

Residential water use varies at three timescales: seasonally, daily, and hourly. For instance, more water is used in summer than in winter; more water commonly is used on Sunday than on other days of the week; and more water commonly is used from 7 a.m. to 9 a.m. than at other times of the day. Therefore, to derive a representative average value for residential water use, data must be averaged at least over an entire year.

Residential water use also varies greatly from housing unit to housing unit. Studies of individual housing units have determined that variability of water-use rates is large due to the many possible types of water uses that may occur alone or simultaneously. Only when large numbers of users are aggregated does some of this variability disappear.

Most of the water delivered to residences goes down the drain after it is used. This return flow either reaches an aquifer by way of an onsite septic tank/drainage field, or more commonly is discharged into a stream by way of a wastewater collection system and public wastewater-treatment plant. In both instances, the water becomes available for re-use. However, some of the water delivered to residences is consumptively used and is not available for re-use. Water used to grow lawns is the primary residential consumptive use. An estimated 42 percent of the water used in the Denver Metropolitan area is used seasonally, primarily for lawn watering (U.S. Army Corps of Engineers, 1986, p. 40). 


\section{Previous Analyses of Residential Water-use Data}

Analyses of residential water use generally are done to estimate average water use. Common approaches are to use regression or time-series analysis. A useful summary of previous work is reported in Maidment and others (1985, p. 5-16).

The regression-analysis approach is used to determine significant explanatory variables that can be used to predict water use. During 1961-66, a landmark nationwide study of residential water use was done under the direction of F.P. Linaweaver, Jr., of Johns Hopkins University. The Linaweaver study (Linaweaver and others, 1966) used a regression-analysis approach, combined with process-oriented empirical relations. Linaweaver determined that inside water use could be estimated using average market value of housing units as an explanatory variable. Outside water use could be estimated based on number of housing units, irrigable area, and lawn water requirement (potential evapotranspiration minus effective precipitation). Maximum daily use could be calculated by assuming that effective precipitation was zero. Maximum hourly use was linearly related to maximum daily use. Design coefficients developed by this study are still in use today (1991).

A summary of explanatory variables that have been used in residential water-use analyses is reported by the U.S. Army Corps of Engineers (1986, p. 49). The principal explanatory variables fall into three classes: weather variables, size variables, and affluence variables. Weather variables, such as temperature and precipitation, are important because they affect outside water use. Size variables, such as persons per housing unit and number of bathrooms, affect inside water use; and size variables, such as lot size, affect outside water use. An additional size variable, number of housing units per area, affects the magnitude of maximum daily and maximum hourly water use. Affluence variables, such as per capita income and market value of house, may affect how much water a user can afford. Authors of the U.S. Army Corps of Engineers (1986) report described a multiple-regression analysis of total municipal water use in the Denver metropolitan area that indicated the following to be significant explanatory variables: Median household income, percent single-family dwellings, lot size, persons per housing unit, service-sector employees per housing unit, nonservice-sector employees per houșing unit, number of days of measurable precipitation, presence of water-use restrictions, and marginal price of water.

Time-series analysis is used to investigate residential water use because the data commonly are collected and tabulated with reference to time. The cyclical nature of water use with its autocorrelative behavior is amenable to analysis using time-series methods. A disadvantage is that time-series analysis operates on a site-specific dataset, whereas a study objective commonly is to extend results from one site to another. Maidment and others (1985) have analyzed municipal water use by combining time-series and empirical techniques.

\section{RESIDENTIAL WATER-USE STUDY OF THE DENVER WATER DEPARTMENT}

Detailed residential water-use data are relatively scarce. Commonly, public-supply systems record total daily water use. However, recorded data may not separate the residential sector from the commercial and industrial sectors. Data also may be available to calculate residential water use by account, using monthly or bimonthly billing records, but these data are inherently limited by the timescale of the billing period. Data at the weekly to hourly scale, aggregated by single residence or homogeneous study site, generally are available only when special studies, such as the Denver Water Department RWUS, are conducted. 


\section{History of the Study}

RWUS data collection began in 1961 as part of the nationwide study by Linaweaver and others (1966) to determine water-use patterns in residential areas. For this nationwide study, a variety of homogeneous study sites were selected wherein aggregate residential water use could be monitored continuously. The water use was measured by closing valves on water mains so that each study site was isolated and served by a single main. Meters were installed with recorders that collected water-flow data at 15-minute intervals. Raw data were aggregated to determine average hourly water-use rates (in gallons per housing unit per day). Average, maximum daily, and maximum hourly water use then could be calculated. These water-use rates then could be related to various explanatory variables. Four sites in Denver (sites G11, M47, N3J, and N8P), along with 36 other sites around the country, were included in this study. Two additional Denver sites were added in April 1965 (sites H29 and N5T). The study was concluded in October 1965, but the Denver Water Department has intermittently collected data from these sites until the present (1991). However, the objective of continued data collection at these sites was to record maximum daily and maximum hourly water use; therefore, data collection occurred during the summer only, and average water use could only be estimated.

In the spring of 1973 , a meter was installed at site NAC (fig. 1), and intermittent data collection began. This site was added because it was a homogeneous, 100-percent metered area that was served by a single water main. All that was required to make it a study site was the installation of a master meter.

In 1980, the Denver Water Department began its 3-inch meter study, named after the diameter of the meters that were installed. The primary goal of this study was to provide data to estimate the difference between metered and flat-rate water use. Eight paired sites containing 20 to 25 houses each were selected (sites E48-G52, NBW-NDW, NHG-NMG, and NLG-NFG, fig. 1) for weekly data collection. Weekly data collection also was reinstated at all pre-existing sites.

In 1981, construction began on a townhouse development just north of site NAC, which interrupted data collection at this site. Upon completion of construction in 1983, data collection resumed at site NAC; the townhouse development was included as a new weekly data-collection site (site NYH).

Weekly data collection was continued at all 16 sites from 1983 through 1987 . Hourly data were collected during varying periods among the 16 sites beginning in June 1986 through December 1987. Beginning in 1988, data collection was scaled back to a monthly schedule. A summary of the period of record for each site is included in the "Supplemental Site Information" section at the back of this report. The data analyzed for this study consisted of the weekly data from 1980 through 1987 and the hourly data during 1986 through 1987 at all 16 sites.

\section{Collection of Data}

The in-line flow meters used in this study measure the volume of water flowing through the water main. A clock-type pointer revolves as water passes through the meter, and a register similar to a car odometer (or, in some instances, a series of clock-type pointers) records the total flow. Although various meter models were used, all models are compound meters that have two or three flow circuits (and respective dials), each most accurate for a given range of flow. Water is routed through the appropriate circuit that provides the most accurate measurement. Through the use of multiple circuits, meter accuracy of plus or minus 3 percent is obtainable. More complete information on the types of meters used is given in the "Supplemental Site Information" section at the back of this report. 
Flow data were recorded using a variety of methods. Most simply, a meter reader visited the site on a regular schedule and read the meter; this method yielded an average water use spanning the time interval since the last visit. This type of data collection was used when only weekly or monthly average water use was desired.

For more frequent measurements, a recording device was installed on the meter. During the Linaweaver study, Fischer-Porter ${ }^{1}$ traffic counters were attached to the meters so that the number of dial revolutions occurring every 15 minutes could be recorded on a paper-punch tape. For the 1986-87 hourly data-collection effort, Omnidata Easylogger data loggers and Hall effect switches were used. Omnidata Easyloggers are data recorders that store data in an EPROM (Erasable Programmable Read Only Memory) chip. A Hall effect switch is a solid-state switch that will pass current when a magnetic field is present. The Hall effect switches were used to sense revolutions of the site water meter dials. If the meter had magnetically driven registers, the Hall effect switch was placed between the register and the meter body. If the meter was mechanically driven, a small magnet was glued to one of the gears and the Hall effect switch was held in place by a plastic spacer. With each revolution of the meter dial, a signal would be passed to the data logger. The data loggers were programmed to record the number of signals (dial revolutions) occurring every 10 minutes. Recorded data were transferred directly from the EPROM to a computer and processed. All data were aggregated from the 10-minute timescale to an hourly timescale.

These modifications do not affect the normal operation of the meter: The meter registers still record the quantity of water that passes through the meter. These recordings

${ }^{1}$ The use of trade or product names in this report is for identification purposes only and does not constitute endorsement by the U.S. Geological Survey. were read at least once a week throughout the 8 years of this study. A typical meter-andrecorder installation used for the RWUS study is shown in figure 2.

At sites NAC and NYH, hourly data are incomplete. The water meters at these two sites have extreme-high-flow circuits, which were not monitored by the data loggers. These circuits generally were not active except during periods of very high water use. However, when the circuits were active, the hourly water-use data from the data loggers are in error because they are missing water. Weekly data for these sites are not affected since the water meters were read manually each week. For 1987, the missed water amounted to 2.4 percent of the data logger totals at site NAC and 0.7 percent at site NYH. Although the quantity of missed water is small and known for each week, the hourly distribution of the missed water is not known. Therefore, maximum daily water use and maximum hourly water use are not reported for these sites.

The data loggers sometimes miss events or malfunction for short periods. The usual reason for missing events is that the Hall effect switch is too far from the magnet. Missing data becomes apparent by plotting hourly data and by comparison of the data-logger totals with weekly water-meter readings. The water meters are highly reliable so their flow totals were considered to reflect true flows. When differences occurred, hourly water use was estimated by using linear interpolation across the period of missing record, while making sure that estimated flow data brought the datalogger totals up to the water-meter totals for the week. Interpolated data are flagged as "estimated" in the computerized dataset. An additional check could be made at sites that contain housing units, which are individually metered for billing purposes, although this type of check was constrained by the length of the billing period (bimonthly). A summary of the percent of estimated data for each study site is given at the back of this report in the 


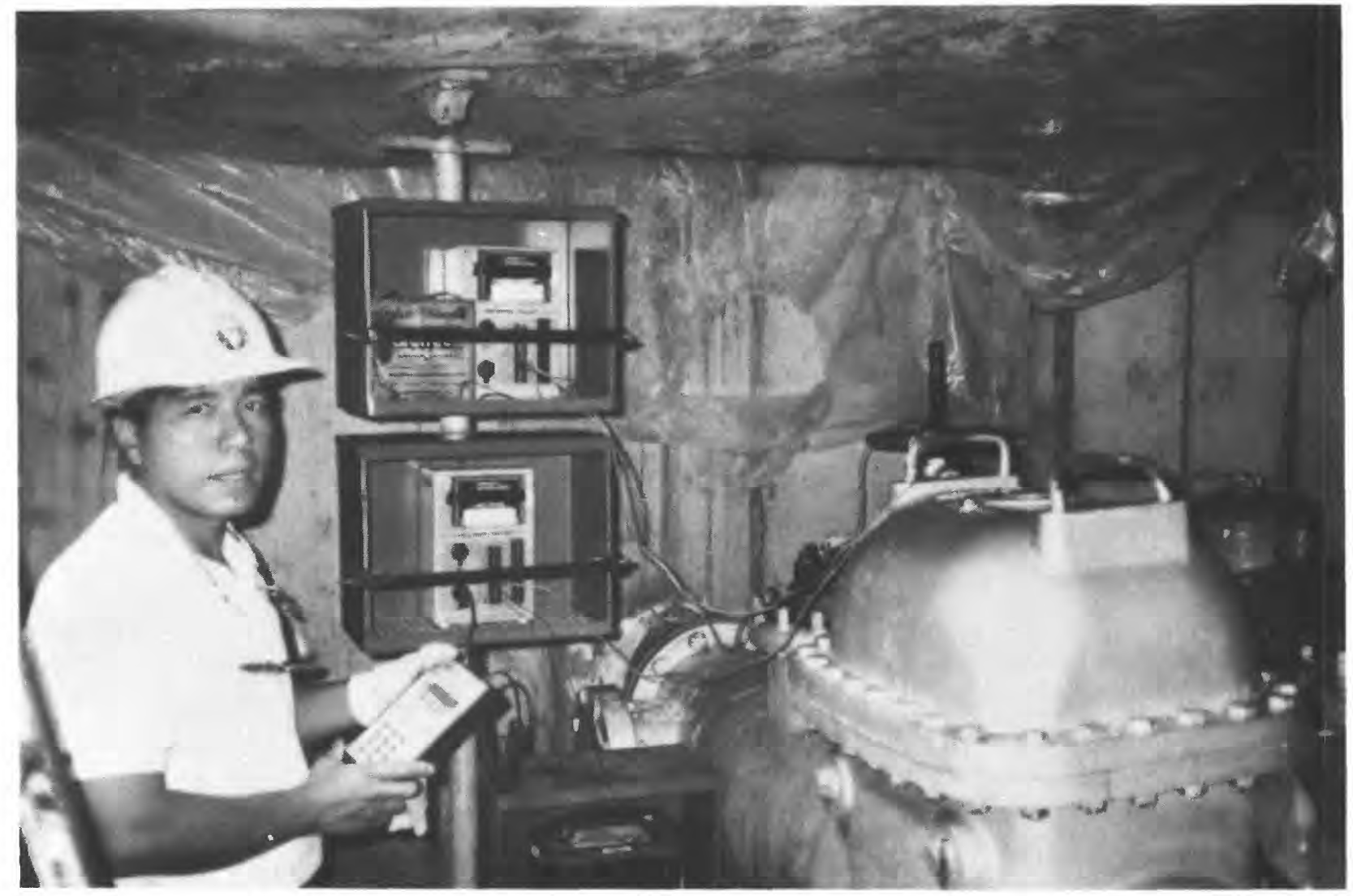

Figure 2.--Typical water-meter site and recorder installation.

section "Supplemental Site Information." Estimates comprised from 1 to 8 percent of the weekly data, and from 1 to 17 percent of the hourly data.

\section{DESCRIPTION OF THE STUDY SITES}

The 16 study sites are located within the City and County of Denver (fig. 1). Descriptive information about the sites is presented in table 1; a more complete description and diagram of each study site is included in the "Supplemental Site Information" section at the back of this report.

The sites range in size from 3.8 to 120 acres, determined by planimetering the area on large-scale maps. This size includes all area within the perimeter of each study site and, thus, includes roads, sidewalks, alleys, and in some instances, small parks.

The study sites contain from 20 to 3,533 housing units. The number of housing units was determined from County Assessor records for 1985 and is equivalent to U.S. Census households. The number of housing units may vary slightly from year to year due to vacancies, but the 1985 data were assumed to be representative for 1980-87. Addition of housing units through construction is considered to be minimal because mature built-out neighborhoods were selected as study sites. Water-use data for this report are standardized by dividing the volumes used by each site (the volume flowing through the meter at the site) by the number of housing units in that site. Therefore, all descriptive variables for each 
Table 1.--Site descriptive variables

[ $\mathrm{ft}^{2}$, square feet; $\mathrm{F}$, flat rate; $\mathrm{M}$, metered; dashes indicate no data]

\begin{tabular}{|c|c|c|c|c|c|c|c|c|}
\hline $\begin{array}{l}\text { Site } \\
\text { desig- } \\
\text { nation }\end{array}$ & $\begin{array}{l}\text { Site } \\
\text { size, } \\
\text { in } \\
\text { acres }\end{array}$ & $\begin{array}{l}\text { Number } \\
\text { of } \\
\text { housing } \\
\text { units }\end{array}$ & $\begin{array}{c}\text { Billing } \\
\text { type }\end{array}$ & $\begin{array}{l}\text { Persons } \\
\text { per } \\
\text { housing } \\
\text { unit }\end{array}$ & $\begin{array}{c}\text { Age } \\
\text { factor }^{1}\end{array}$ & $\begin{array}{l}\text { Assessed } \\
\text { value, in } \\
\text { thousands } \\
\text { of dollars } \\
\text { per hous- } \\
\text { ing unit }\end{array}$ & $\begin{array}{l}\text { Lot size, } \\
\text { in thou- } \\
\text { sands of } \\
\mathrm{ft}^{2} \text { per } \\
\text { housing } \\
\text { unit }\end{array}$ & $\begin{array}{l}\text { Lawn } \\
\text { size, } \\
\text { in thou- } \\
\text { sands of } \\
\mathrm{ft}^{2} \text { per } \\
\text { housing } \\
\text { unit }\end{array}$ \\
\hline E48 & 3.8 & 23 & $\mathrm{~F}$ & 2.3 & 0.33 & 20 & 5.4 & 2.3 \\
\hline G11 & 39 & 169 & $\mathrm{~F}$ & 1.9 & 39 & 20 & 6.8 & 3.4 \\
\hline G52 & 7.3 & 20 & $\mathrm{M}$ & 2.8 & 31 & 19 & 11 & 6.1 \\
\hline $\mathrm{H} 29$ & 50 & 297 & $\mathrm{~F}$ & 3.0 & .44 & 8.5 & 3.0 & .5 \\
\hline M47 & 96 & 349 & $\mathrm{~F}$ & 3.0 & .40 & 11 & 6.1 & 3.1 \\
\hline N3J & 120 & 305 & $\mathrm{~F}$ & 2.5 & .35 & 41 & 11 & 5.6 \\
\hline N5T & 54 & 225 & F & 2.3 & -1 & 13 & 6.7 & 3.4 \\
\hline N8P & 86 & 3,533 & $\mathrm{M}$ & 1.4 & .14 & 10 & .5 & .02 \\
\hline NAC & 94 & 329 & $\mathrm{M}$ & 3.0 & 31 & 28 & 8.5 & 4.8 \\
\hline NBW & 6.8 & 26 & F & 2.7 & .30 & 22 & 8.7 & 4.6 \\
\hline NDW & 5.9 & 25 & $\mathrm{M}$ & 2.8 & .32 & 21 & 7.2 & 3.8 \\
\hline NFG & 3.8 & 20 & $\mathrm{M}$ & 2.3 & 23 & 19 & 7.5 & 4.3 \\
\hline NHG & 8.4 & 22 & $\mathrm{~F}$ & 2.6 & .29 & 26 & 11 & 7.6 \\
\hline NLG & 4.8 & 22 & F & 2.3 & .23 & 18 & 7.0 & 4.0 \\
\hline NMG & 9.2 & 23 & $\mathrm{M}$ & 2.5 & .34 & 43 & 13 & 6.9 \\
\hline NYH & 38 & 261 & $\mathrm{M}$ & 1.9 & --1 & 15 & 2.8 & 2.0 \\
\hline
\end{tabular}

${ }^{1}$ Age factor is the ratio of persons under 18 plus persons 65 and older compared to total population of the site.

site, such as lot size, also are reported on a perhousing-unit basis.

For billing purposes, water use is metered within seven of the study sites, whereas water use is billed primarily on a flat-rate schedule within the remaining nine sites. Billing type generally is believed to affect water use because metered customers are aware of the quantity of water they use and can change their behavior to decrease their water bill. Flatrate customers, on the other hand, are not aware of how much water they are using because it is not metered, and they are billed the same amount regardless of the quantity of water they use.

Water-billing rates increased several times during 1980-87 for metered and flat-rate customers. Metered customers were billed bimonthly in a decreasing block-rate schedule. In 1980, the rate per thousand gallons was $\$ 0.68$ for the first 30,000 gallons and $\$ 0.58$ for the next 70,000 gallons; in 1987, the rate was $\$ 0.83$ for the first 30,000 gallons and $\$ 0.67$ for the next 70,000 gallons. For an average metered housing unit, this amounts to an annual water bill of about $\$ 140$ in 1980 and 
$\$ 165$ in 1987 , or about a 20 -percent increase. For flat-rate customers, there is a minimum bimonthly service charge plus additional cost increments based on number of rooms, number of bathrooms, number of toilets, number of water-using devices, and lot size. Rate increases for flat-rate customers were similar to those for metered customers. Because the annual increase in water cost was not much different than the inflation rate, and because water is relatively inexpensive in Denver compared to other living expenses, it was assumed that increases in water cost did not affect water use during the study period.

The average number of persons per housing unit for each site was estimated by matching study-site boundaries as closely as possible with U.S. Census blocks from the 1980 Census; the smallest sites were equivalent in size to about one Census block (but rarely matched boundaries exactly with a single Census block), whereas the largest sites encompassed as many as 17 Census blocks. Values ranged from 1.4 to 3.0 persons per housing unit. Because 1990 Census data were not available, it was assumed that the 1980 data were representative for the entire study period. General socioeconomic trends during the study period suggest that if any change did occur, it would be toward smaller persons-perhousing-unit values.

An age factor was determined for each site as a surrogate for number of people at home during the day; this factor consisted of the ratio of persons under 18 plus persons 65 and older compared to the total population at the site, as determined from U.S. Census block data. This ratio ranged from 0.14 to 0.44 for the 14 sites with data.

Average assessed property value was calculated using data from County Assessor files. The data are for 1985. Assessed value is roughly equivalent to one-third of the market value of a property. Among study sites, average assessed value ranged from $\$ 8,500$ to $\$ 43,000$ per housing unit.
Average lot size was calculated using data from County Assessor files. Legal lot size was used, so sidewalk, street buffer areas, and alleyways are not included in the size calculations. Most of the smaller study sites have little variation in lot size, whereas there is considerable variation in lot size in the large study sites. Average lot size ranged from 500 to 13,000 square feet per housing unit.

Lawn size was measured (by pacing) at a representative sample of housing units within each study site. Average lawn size for each study site was then estimated by adjusting the sample average using a lot-size ratio (average lot size of sample compared to average lot size for the study site). Average lawn size ranged from 20 to 7,600 square feet per housing unit. Lawn size correlated well with lot size and can be approximated from lot size using the linear relation:

$$
\text { LAWN }=0.6 \text { LOT }-500,
$$

where LAWN = regression estimated lawn size, in square feet; and

LOT $=$ lot size, in square feet.

This equation had a coefficient of determination of 0.92 , and the standard error of the slope was 0.04 . Although this relation fits the data well, the data plot on a slight curve, indicating that a power relation might be more appropriate. This linear regression predicts lawn sizes comparable to those predicted by an earlier equation developed using data from Northglenn and Fort Collins, Colorado (Mary Hoddinott, P.E., Denver Water Department, oral commun., 1990), in the lot range of $4,000-8,000$ square feet but predicts smaller lawn sizes than the earlier equation for lots larger than 8,000 square feet. The difference at large lot sizes may arise because the earlier study examined irrigable area, whereas the present study examined only that part of the lot actually in lawn. Hence, the equations agree for small-tomoderate size lots where available space is likely to be landscaped but deviate for large lots where there is more likelihood for 
additional space to be used for purposes other than landscaping.

\section{WATER USE AT STUDY SITES}

The purpose of this section is to describe the water-use patterns at the study sites using graphs and statistical summaries. An analysis of the possible causes of these patterns is discussed in the "Analysis of Data" section.

Summary statistics for water use at the study sites are listed in table 2. Average water use for the 8-year study period ranged from 163 GUD at site N8P to 804 GUD at site N3J. The variability of average use from year to year was quantified by calculating average use for each year and then calculating the coefficient of variation (standard deviation divided by mean) of these annual averages. The coefficients of variation for the study sites were fairly small, ranging from 0.04 to 0.18 ; that is, average water use did not vary much from year to year.

Water use does vary significantly, however, within the course of a year. A typical timeseries plot of weekly average water use (fig. 3) indicates a steady small rate of water use in the winter and large peak rates of water use in the summer. The winter use is roughly equivalent to inside water use, because at low air temperatures outside water use is not likely. As temperature rises in the spring, outside water use increases as people begin to water their lawns and gardens. The summer water-use rates remain large except when rainfall occurs or when the temperature drops. Of the two sites shown in figure 3 , summer water-use rates are larger at site NHG than at site E48, probably because lawns are larger at site NHG.

Residential water use also varies from day to day. This daily variability primarily is dependent on weather during the summer, although there is a discernible pattern indicating that lawn sprinkling water use increases during the weekends. During the winter, average use is larger on Sunday, Saturday, and
Monday than on the other days of the week: this pattern is statistically significant at a level of 0.05 at 10 of the 16 study sites.

Finally, residential water use varies hourly. Hourly variations are important because maximum hourly use affects the sizing of water transmission lines. Graphs showing hourly water use at each of the study sites are presented in figures 4-19. When comparing these graphs, note that the $y$-axis scales are different for each graph--this allows more detail to be visible in each graph. These graphs are based on the hourly dataset collected beginning in June 1986 (for most sites) through December 1987. Data are aggregated for winter, which is defined as the months of December, January, and February, and for summer, which is defined as the months of June, July, and August. Each graph shows the range of hourly values for each hour of the day, a one-standard-deviation band around the average value for each hour, and average hourly curves for weekdays, Saturday, and Sunday. These graphs show differences between some of the study sites, while indicating similarities among others.

Study site $\mathrm{H} 29$ (fig. 7) is unique among study sites for several reasons: It is an urban site with relatively small average assessed value, lawn size is small, and several commercial buildings (grocery stores, auto-repair shop, community center), and irrigated parks exist within the study site. Water used at these commercial buildings and irrigated parks passes through the site's master meter and so is included in the data reported here. However, the commercial buildings are not counted as housing units, and the area of the parks was not included in the site's average lawn size. These un-accounted-for factors affect the reliability of data from this site. This study site has the third smallest average water use (356 GUD) among study sites. Winter water use is similar to other sites but summer use patterns are unique: there is a broad daily peak of relatively small magnitude probably caused by random lawn watering, with a large secondary 
Table 2.--Summary statistics for water use at study sites

[Use is in gallons per housing unit per day. All other statistics are dimensionless. CV, coefficient of variation; Max, maximum; dashes indicate no data]

\begin{tabular}{|c|c|c|c|c|c|c|c|c|c|c|c|}
\hline \multirow[b]{2}{*}{ Site } & \multicolumn{6}{|c|}{$1980-87$} & \multicolumn{5}{|c|}{$1986-87^{1}$} \\
\hline & $\begin{array}{c}\text { Average } \\
\text { water } \\
\text { use }\end{array}$ & $\begin{array}{c}\mathrm{CV} \text { of } \\
\text { annual } \\
\text { average } \\
\text { use } \\
\end{array}$ & $\begin{array}{c}\text { Average } \\
\text { base } \\
\text { use }^{2}\end{array}$ & $\begin{array}{c}\text { CV of } \\
\text { annual } \\
\text { base } \\
\text { use }\end{array}$ & $\begin{array}{c}\text { Average } \\
\text { seasonal } \\
\text { use }^{2}\end{array}$ & $\begin{array}{c}\text { CV of } \\
\text { annual } \\
\text { seasonal } \\
\text { use } \\
\end{array}$ & $\begin{array}{c}\text { Average } \\
\text { water } \\
\text { use }\end{array}$ & $\begin{array}{c}\text { Max } \\
\text { daily } \\
\text { use }\end{array}$ & $\begin{array}{c}\text { Max } \\
\text { hourly } \\
\text { use }\end{array}$ & $\begin{array}{l}\text { Max daily } \\
\text { to average } \\
\text { use ratio }\end{array}$ & $\begin{array}{l}\text { Max hourly } \\
\text { to average } \\
\text { use ratio }\end{array}$ \\
\hline E48 & 381 & 0.09 & 192 & 0.10 & 189 & 0.16 & $\begin{array}{l}348 \\
356\end{array}$ & $\begin{array}{l}1,095 \\
1,314\end{array}$ & $\begin{array}{l}3,318 \\
3,735\end{array}$ & $\begin{array}{l}3.15 \\
3.69\end{array}$ & $\begin{array}{r}9.53 \\
10.49\end{array}$ \\
\hline G11 & 459 & .10 & 194 & .09 & 265 & .14 & $\begin{array}{l}458 \\
416\end{array}$ & 1,435 & 3,569 & $3 . \overline{5}$ & $\overline{8.58}$ \\
\hline G52 & 431 & .11 & 190 & .14 & 241 & .18 & $\begin{array}{l}482 \\
461\end{array}$ & $\begin{array}{l}2,096 \\
2,074\end{array}$ & $\begin{array}{l}6,612 \\
6,960\end{array}$ & $\begin{array}{l}4.35 \\
4.50\end{array}$ & $\begin{array}{l}13.72 \\
15.10\end{array}$ \\
\hline $\mathrm{H} 29$ & 356 & .05 & 193 & .09 & 163 & .17 & $\begin{array}{l}360 \\
331\end{array}$ & $\begin{array}{r}1,121 \\
916\end{array}$ & $\begin{array}{l}1,491 \\
1,454\end{array}$ & $\begin{array}{l}3.11 \\
2.77\end{array}$ & $\begin{array}{l}4.14 \\
4.39\end{array}$ \\
\hline M47 & 606 & .09 & 307 & .05 & 299 & .20 & $\begin{array}{l}694 \\
647\end{array}$ & $\begin{array}{l}1,980 \\
2,019\end{array}$ & $\begin{array}{l}3,469 \\
3,840\end{array}$ & $\begin{array}{l}2.85 \\
3.12\end{array}$ & $\begin{array}{l}5.00 \\
5.94\end{array}$ \\
\hline N3J & 804 & .10 & 229 & .18 & 575 & .12 & $\begin{array}{l}836 \\
754\end{array}$ & $\begin{array}{l}2,946 \\
2,667\end{array}$ & $\begin{array}{l}5,851 \\
5,453\end{array}$ & $\begin{array}{l}3.52 \\
3.54\end{array}$ & $\begin{array}{l}7.00 \\
7.23\end{array}$ \\
\hline N5T & 526 & .18 & 274 & .11 & 252 & .31 & $\begin{array}{l}485 \\
443\end{array}$ & $\begin{array}{l}1,554 \\
1,578\end{array}$ & $\begin{array}{l}2,851 \\
2,941\end{array}$ & $\begin{array}{l}3.20 \\
3.56\end{array}$ & $\begin{array}{l}5.88 \\
6.64\end{array}$ \\
\hline N8P & 163 & .04 & 138 & .06 & 25 & .27 & $\begin{array}{l}166 \\
158\end{array}$ & $\begin{array}{l}489 \\
239\end{array}$ & $\begin{array}{l}774 \\
412\end{array}$ & $\begin{array}{l}2.95 \\
1.51\end{array}$ & $\begin{array}{l}4.66 \\
2.61\end{array}$ \\
\hline NAC & 428 & .05 & 230 & .05 & 198 & .08 & $\begin{array}{l}458 \\
433\end{array}$ & -- & -- & -- & - \\
\hline NBW & 563 & .09 & 200 & .17 & 363 & .21 & $\begin{array}{l}544 \\
492\end{array}$ & 2,166 & $5, \overline{-}$ & $4 . \overline{40}$ & $11 . \overline{-}$ \\
\hline NDW & 438 & .07 & 204 & .06 & 234 & .19 & $\begin{array}{l}445 \\
421\end{array}$ & $\begin{array}{l}2,173 \\
1,828\end{array}$ & $\begin{array}{l}4,570 \\
5,372\end{array}$ & $\begin{array}{l}4.88 \\
4.34\end{array}$ & $\begin{array}{l}10.27 \\
12.76\end{array}$ \\
\hline NFG & 432 & .13 & 201 & .05 & 231 & .25 & $\begin{array}{l}438 \\
426\end{array}$ & 1,822 & 5,568 & $4 . \overline{28}$ & $13 . \overline{-}$ \\
\hline NHG & 656 & .13 & 200 & .15 & 456 & .17 & $\begin{array}{l}671 \\
573\end{array}$ & 3,603 & $\begin{array}{r}-- \\
7,723\end{array}$ & $6 . \overline{29}$ & 13.48 \\
\hline NLG & 487 & .18 & 204 & .10 & 283 & .28 & $\begin{array}{l}473 \\
400\end{array}$ & 1,836 & 5,454 & $4 . \overline{-}$ & 13.63 \\
\hline NMG & 762 & .12 & 230 & .16 & 532 & .12 & $\begin{array}{l}840 \\
726\end{array}$ & $\begin{array}{l}3,289 \\
3,353\end{array}$ & $\begin{array}{l}8,191 \\
7,972\end{array}$ & $\begin{array}{l}3.92 \\
4.62\end{array}$ & $\begin{array}{r}9.75 \\
10.98\end{array}$ \\
\hline NYH & 331 & .09 & 137 & .04 & 194 & .23 & $\begin{array}{l}338 \\
281\end{array}$ & - & -- & - & -- \\
\hline
\end{tabular}

${ }^{1}$ First line of data for each site is for 1986 calendar year; second line of data is for 1987 calendar year.

2Base and seasonal use are defined as discussed in the section "Analysis of Data." 

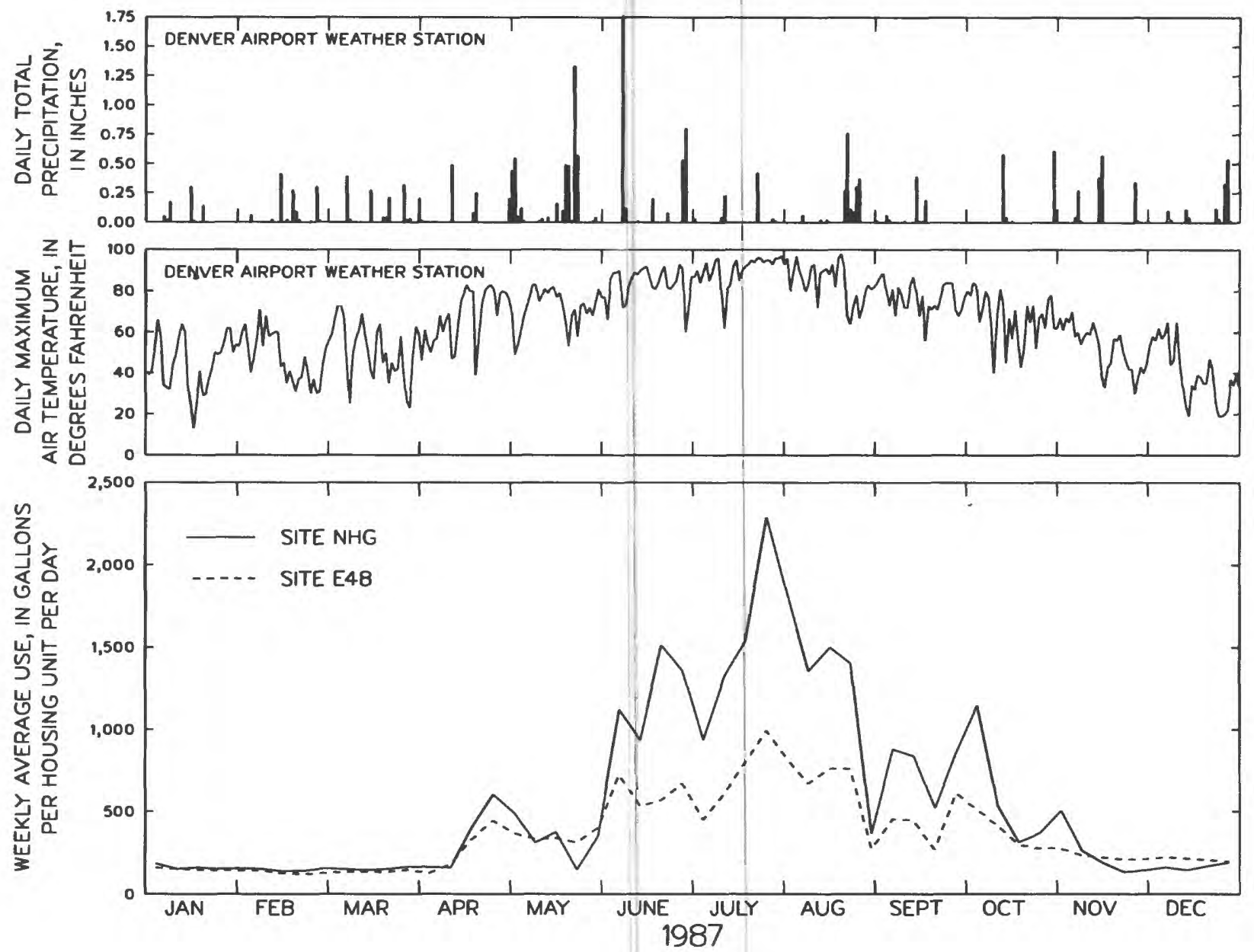

Figure 3.--Weekly average water use at sites NHG and E48 and daily total precipitation and daily maximum air temperature at the Denver Airport weather station, 1987. 
EXPLANATION

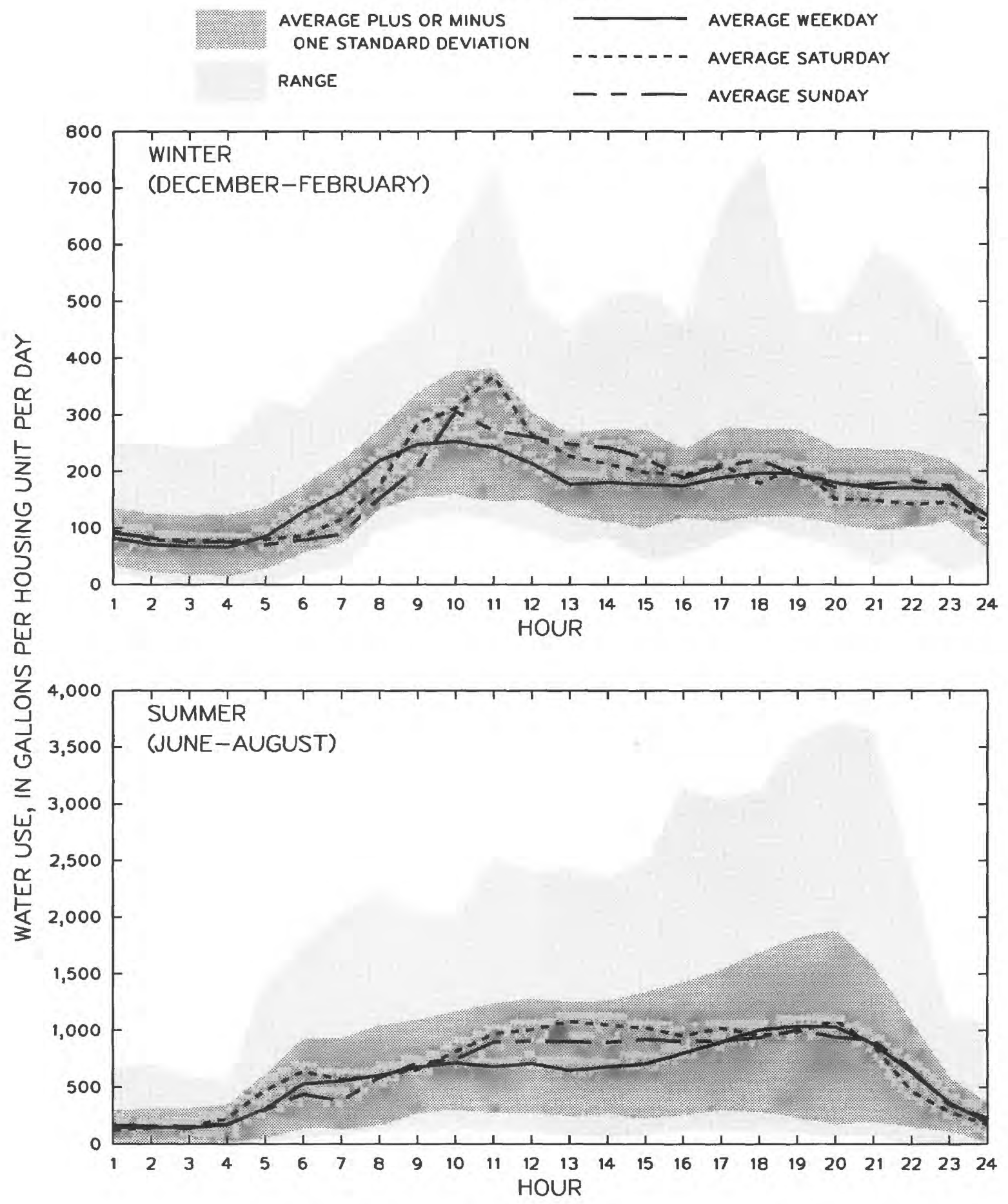

Figure 4.--Hourly water use at site E48, for winter and summer, June 1986-December 1987. 


\section{EXPLANATION}

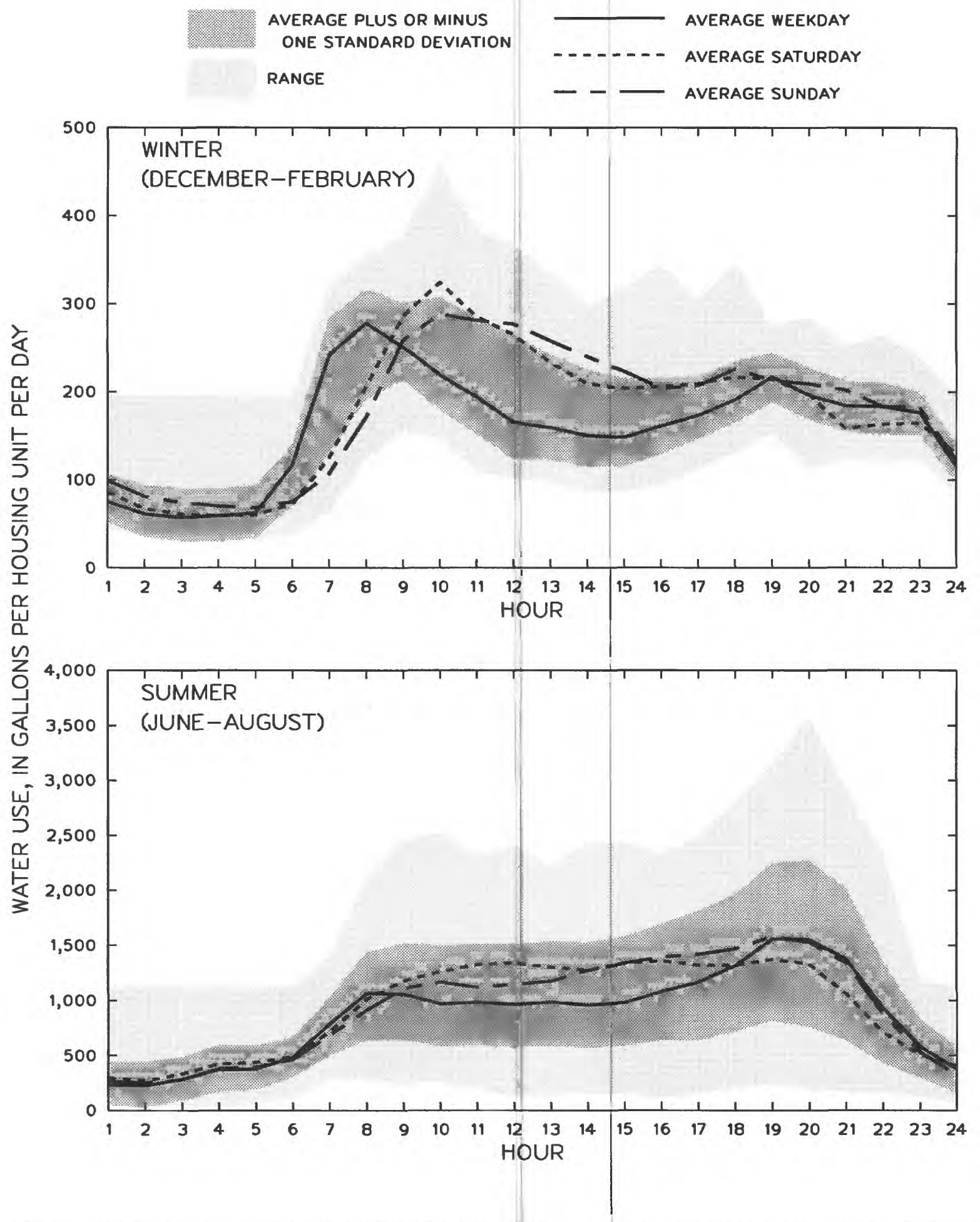

Figure 5.--Hourly water use at site G11, for winter and summer, July 1986-December 1987. 


\section{EXPLANATION}

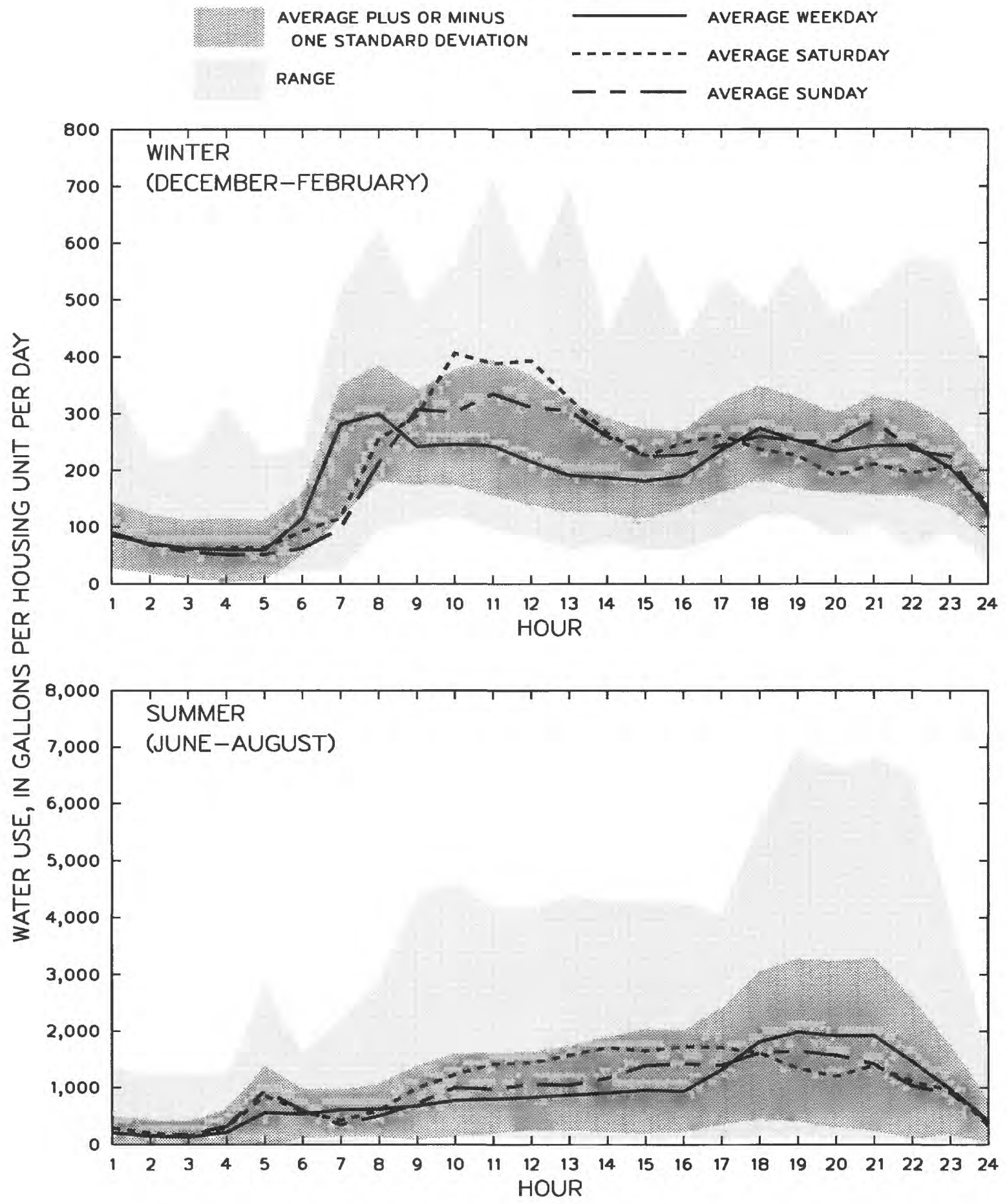

Figure 6.--Hourly water use at site G52, for winter and summer, June 1986-December 1987. 


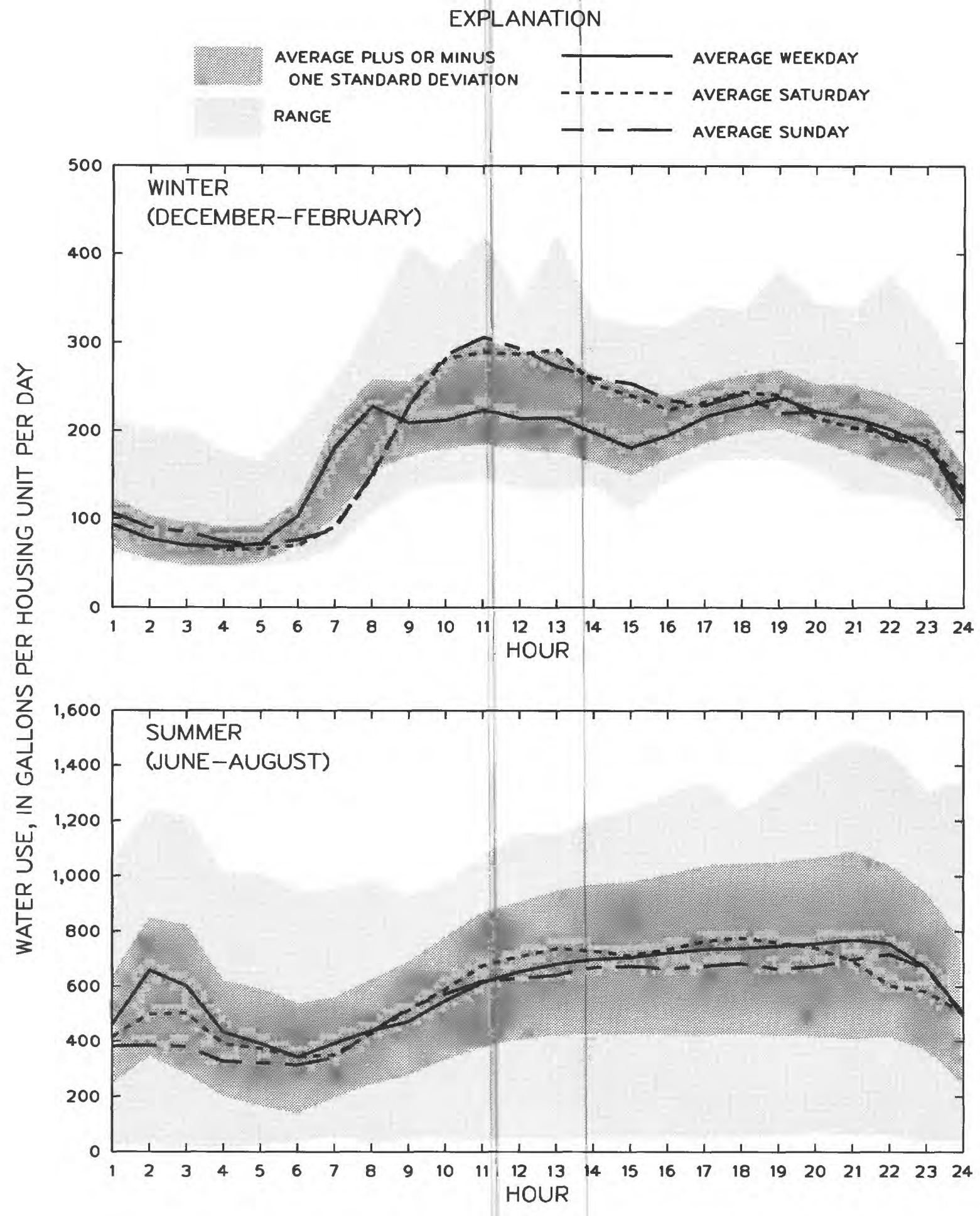

Figure 7.--Hourly water use at site H29, for winter and summer, June 1986-December 1987. 


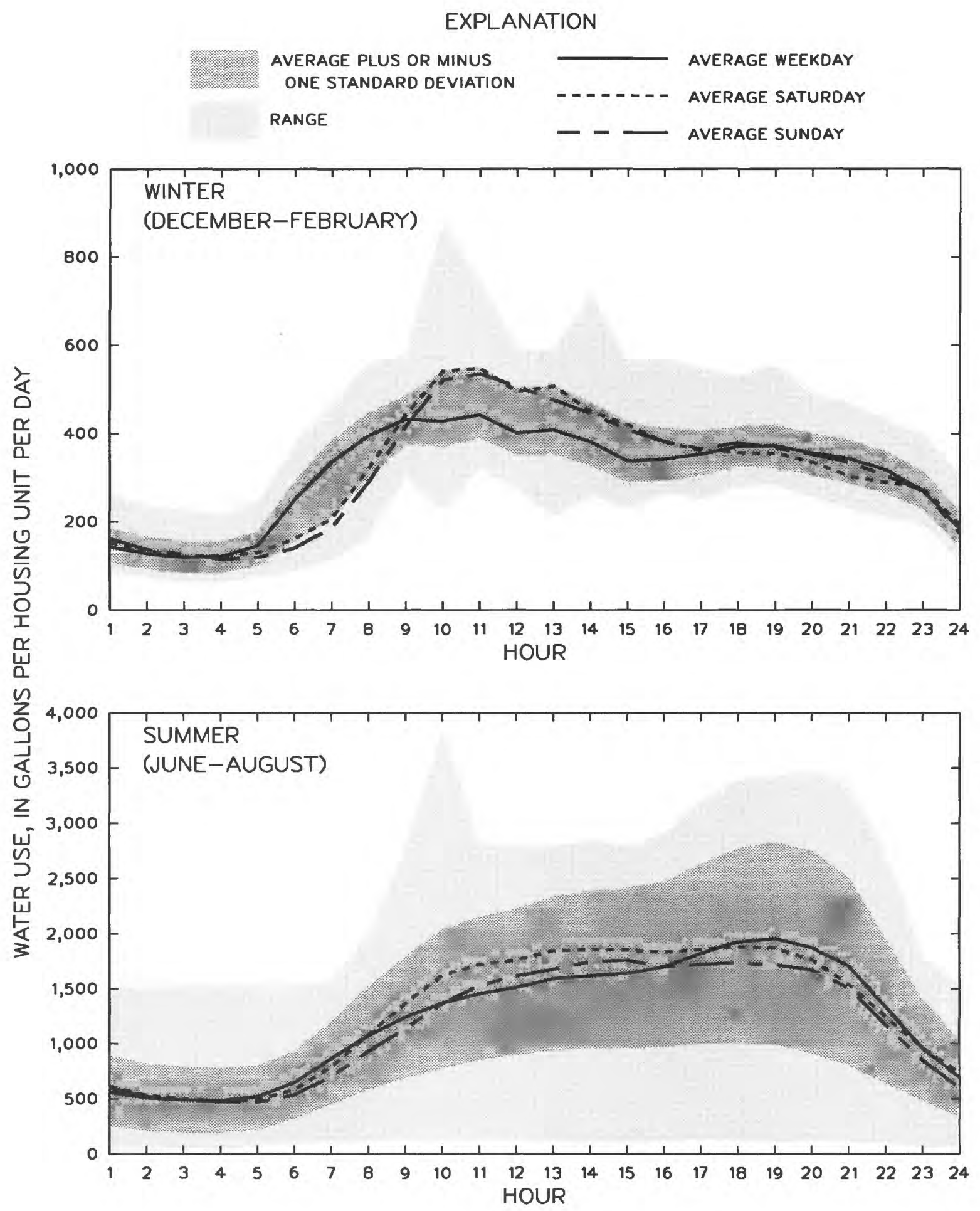

Figure 8.--Hourly water use at site M47, for winter and summer, June 1986-December 1987. 


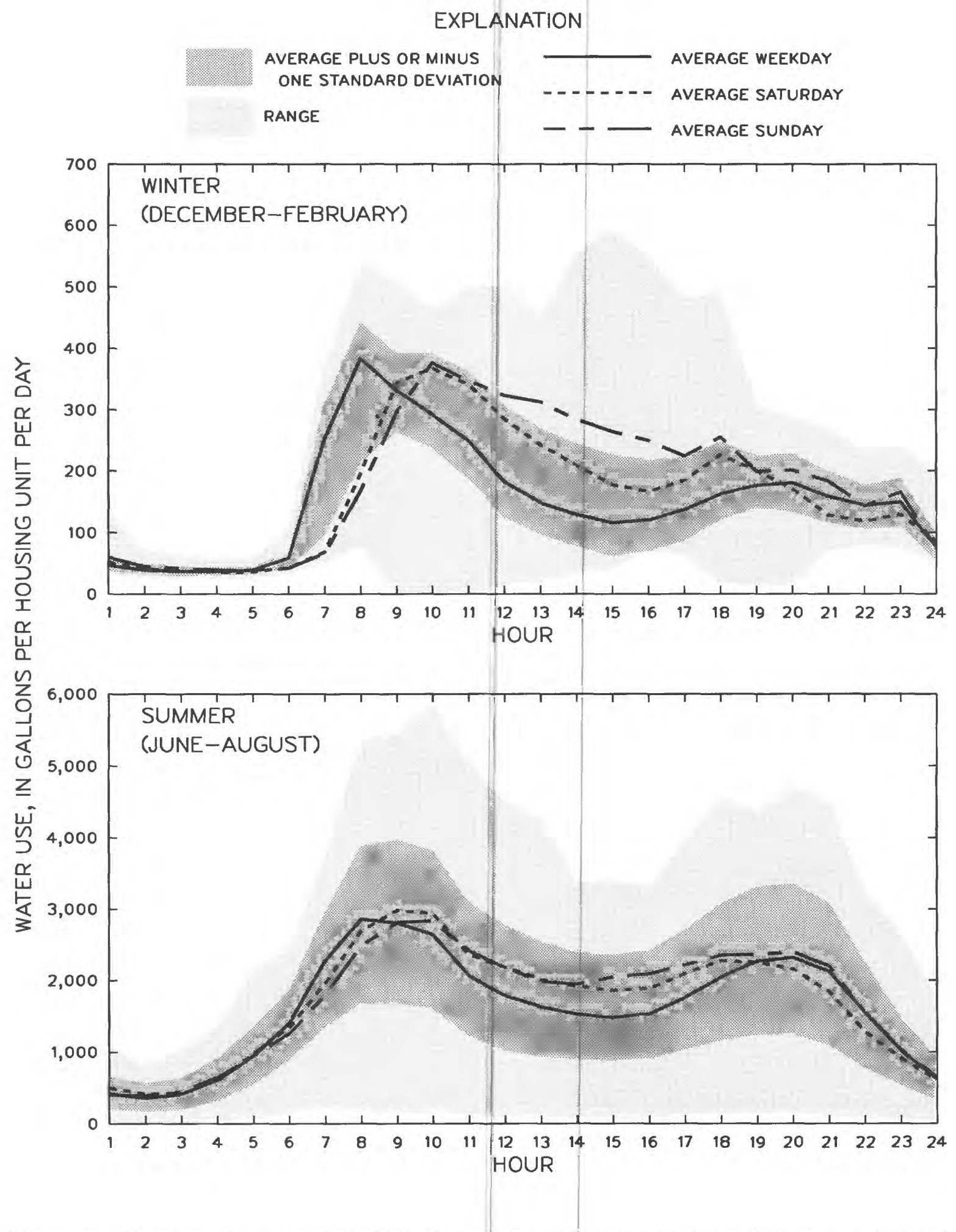

Figure 9.--Hourly water use at site N3J, for winter and summer, June 1986-December 1987. 


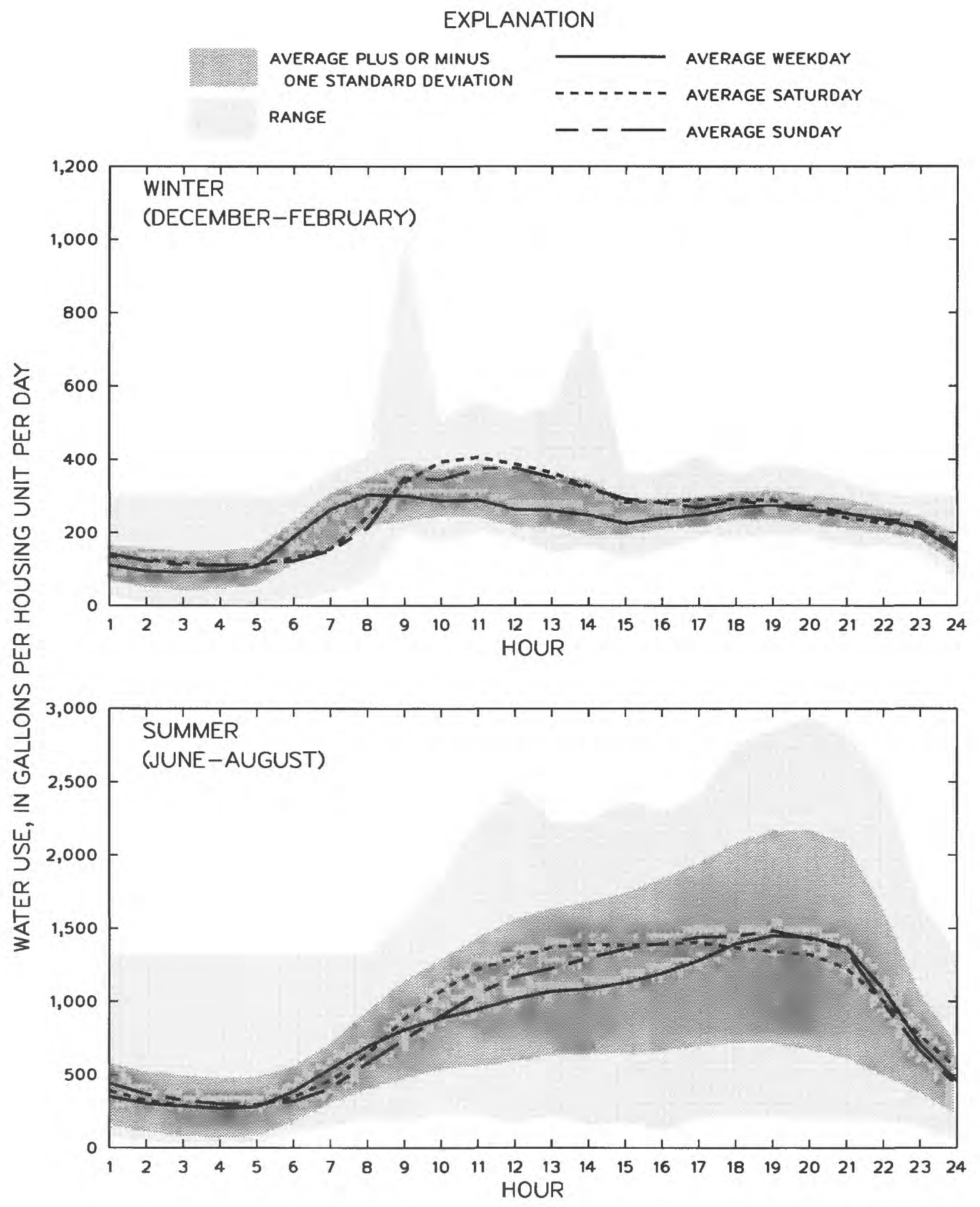

Figure 10.--Hourly water use at site N5T, for winter and summer, June 1986-December 1987. 


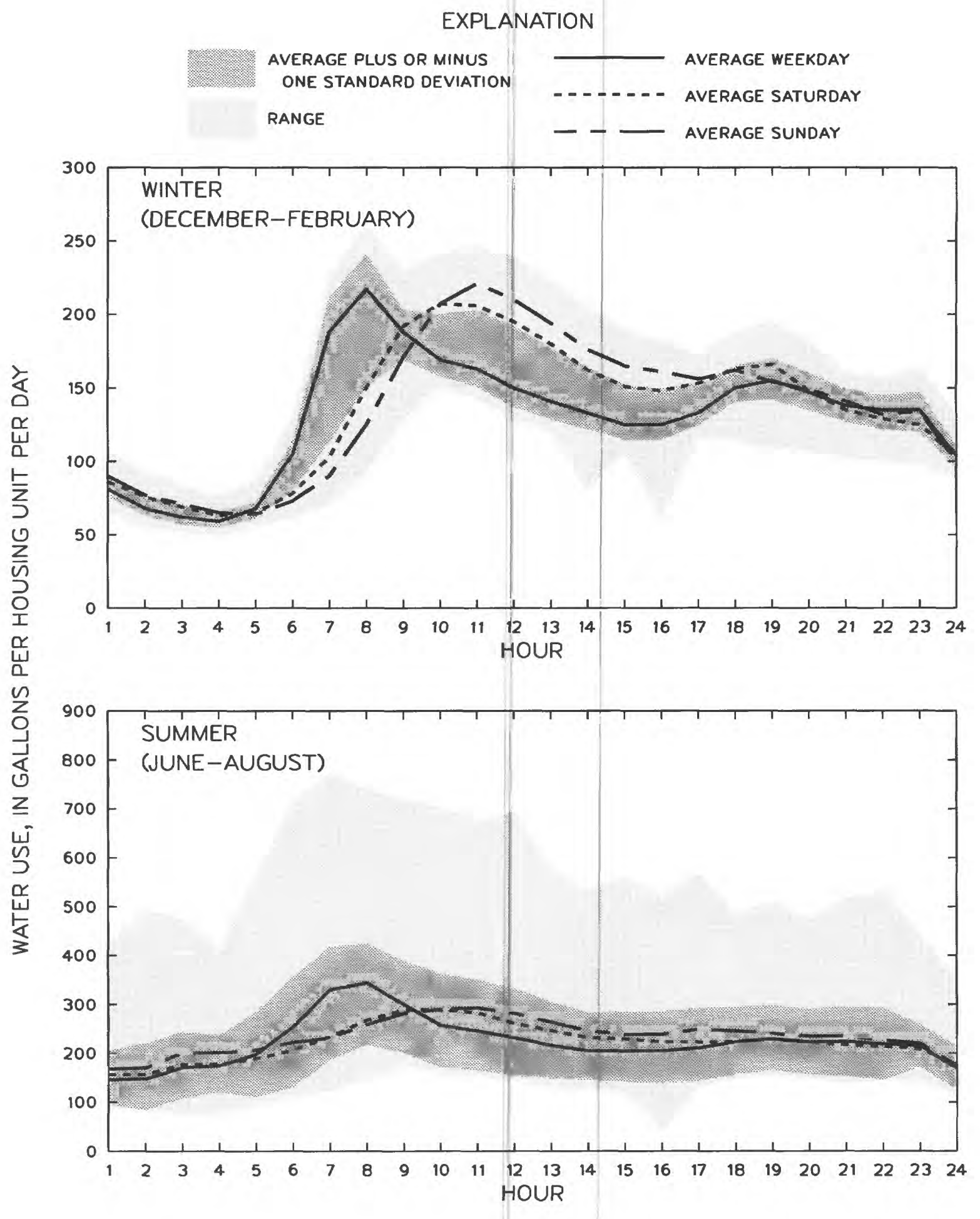

Figure 11.--Hourly water use at site N8P, for winter and summer, June 1986-December 1987. 


\section{EXPLANATION}

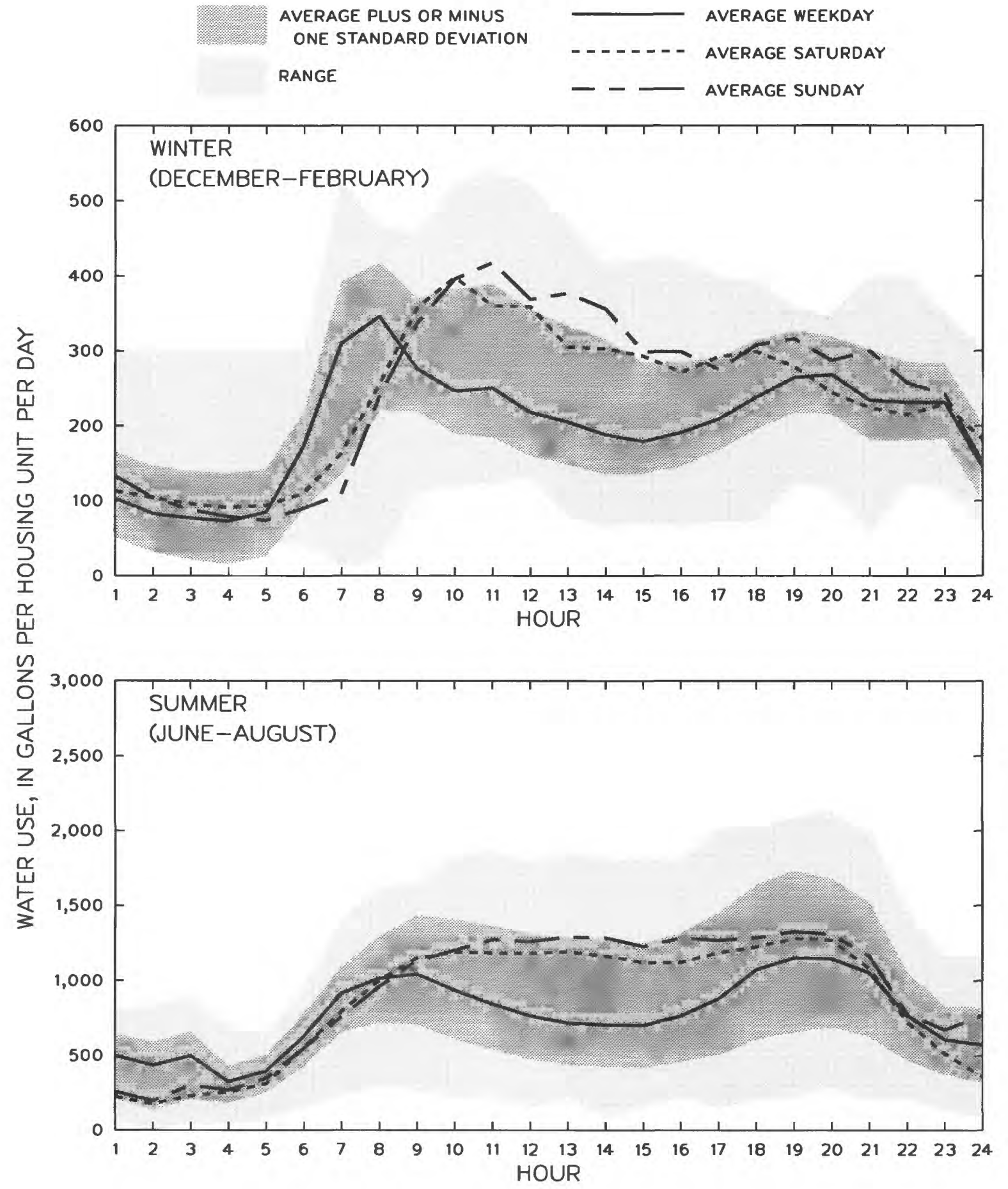

Figure 12.--Hourly water use at site NAC, for winter and summer, January 1987December 1987. 


\section{EXPLANATION}

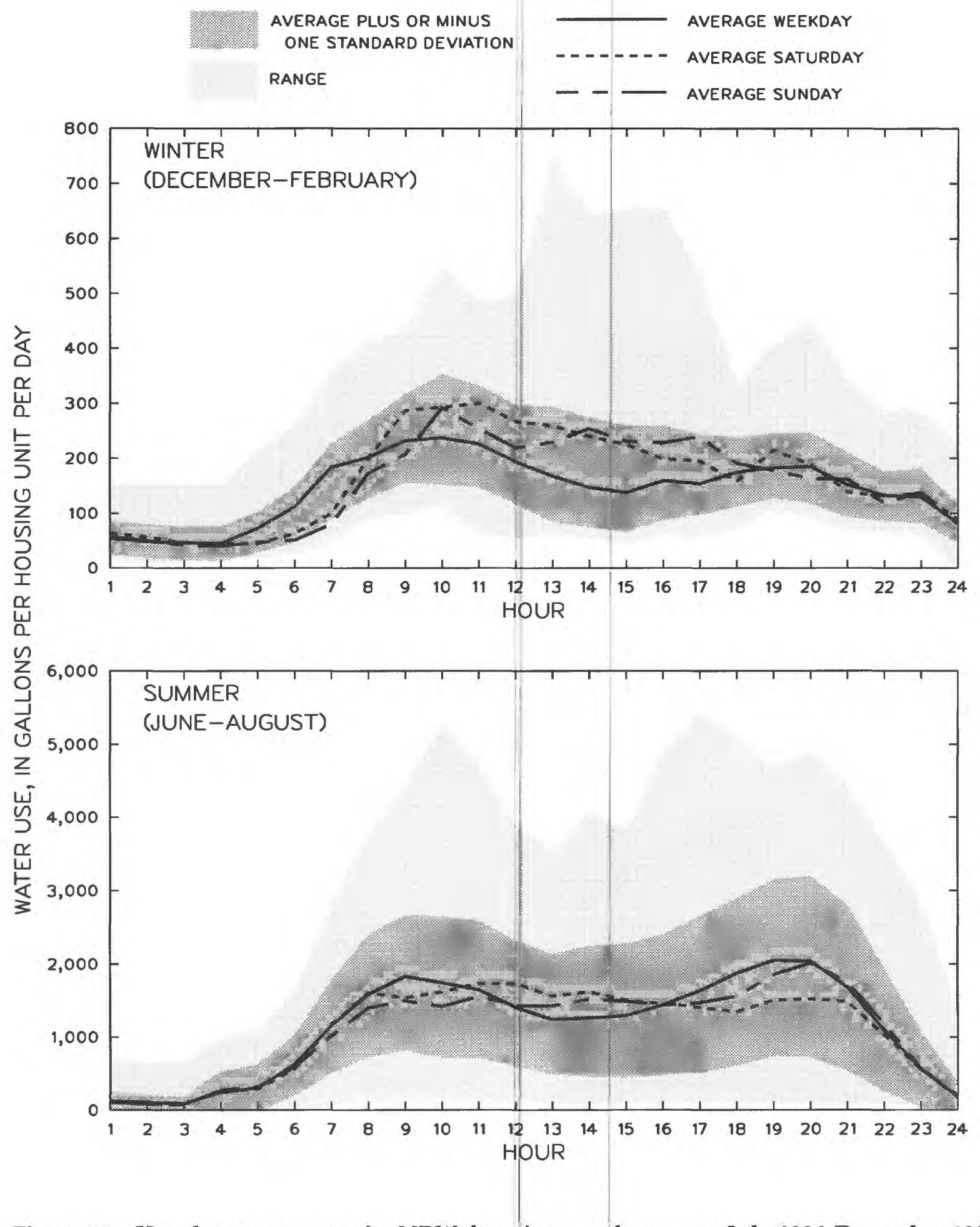

Figure 13.--Hourly water use at site NBW, for winter and summer, July 1986-December 1987. 


\section{EXPLANATION}

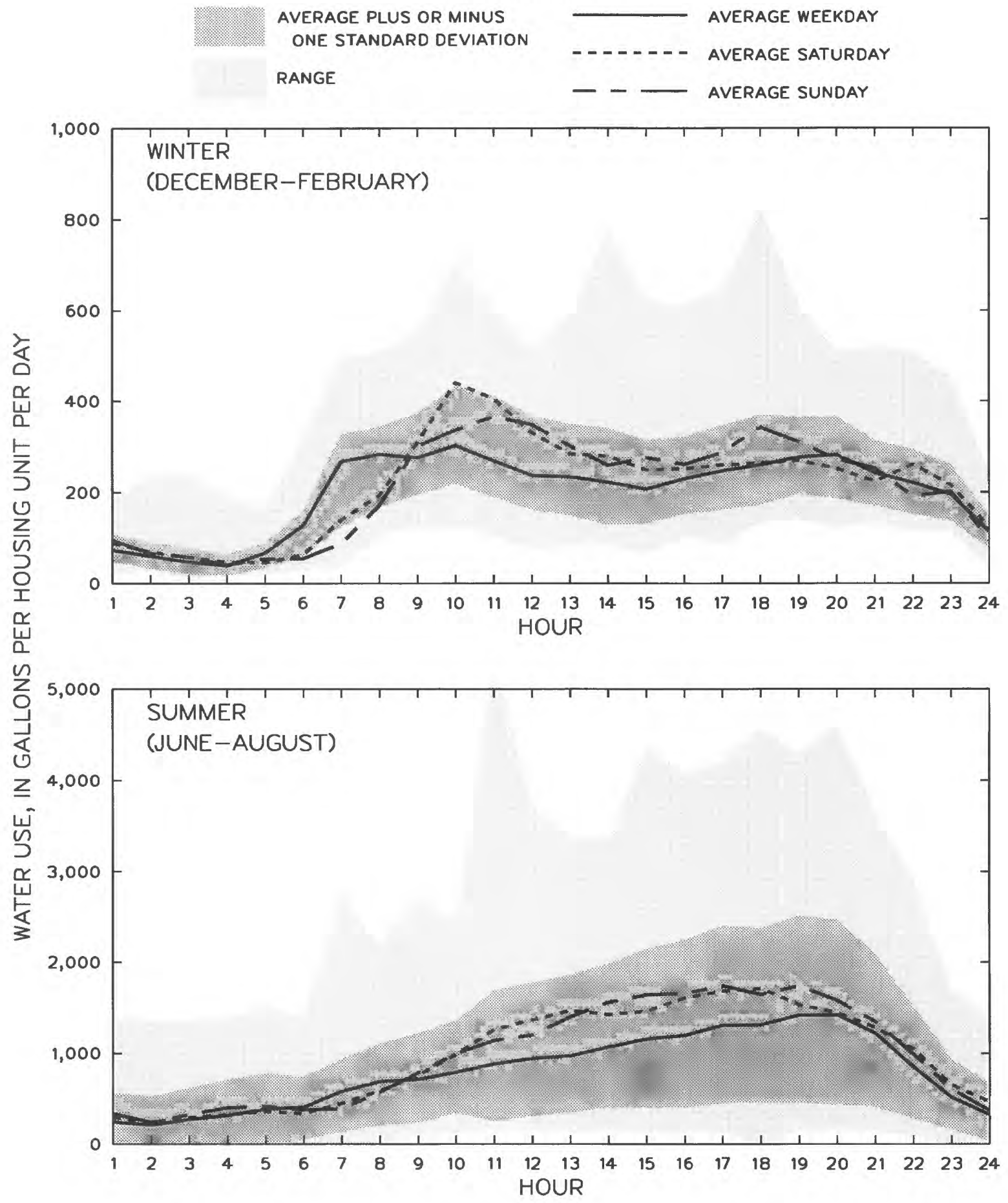

Figure 14.--Hourly water use at site NDW, for winter and summer, June 1986-December 1987. 


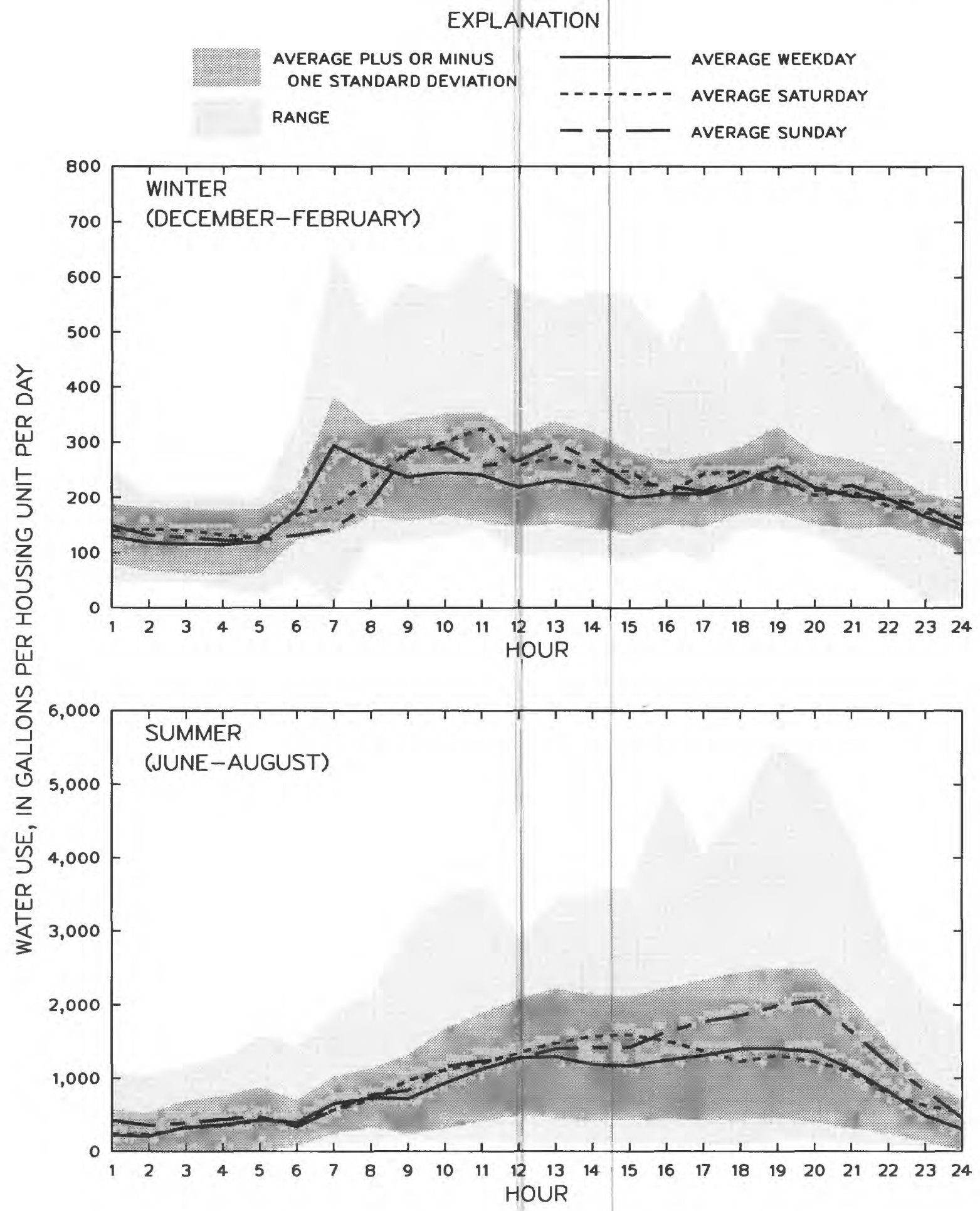

Figure 15.--Hourly water use at site NFG, for winter and summer, August 1986December 1987. 


\section{EXPLANATION}

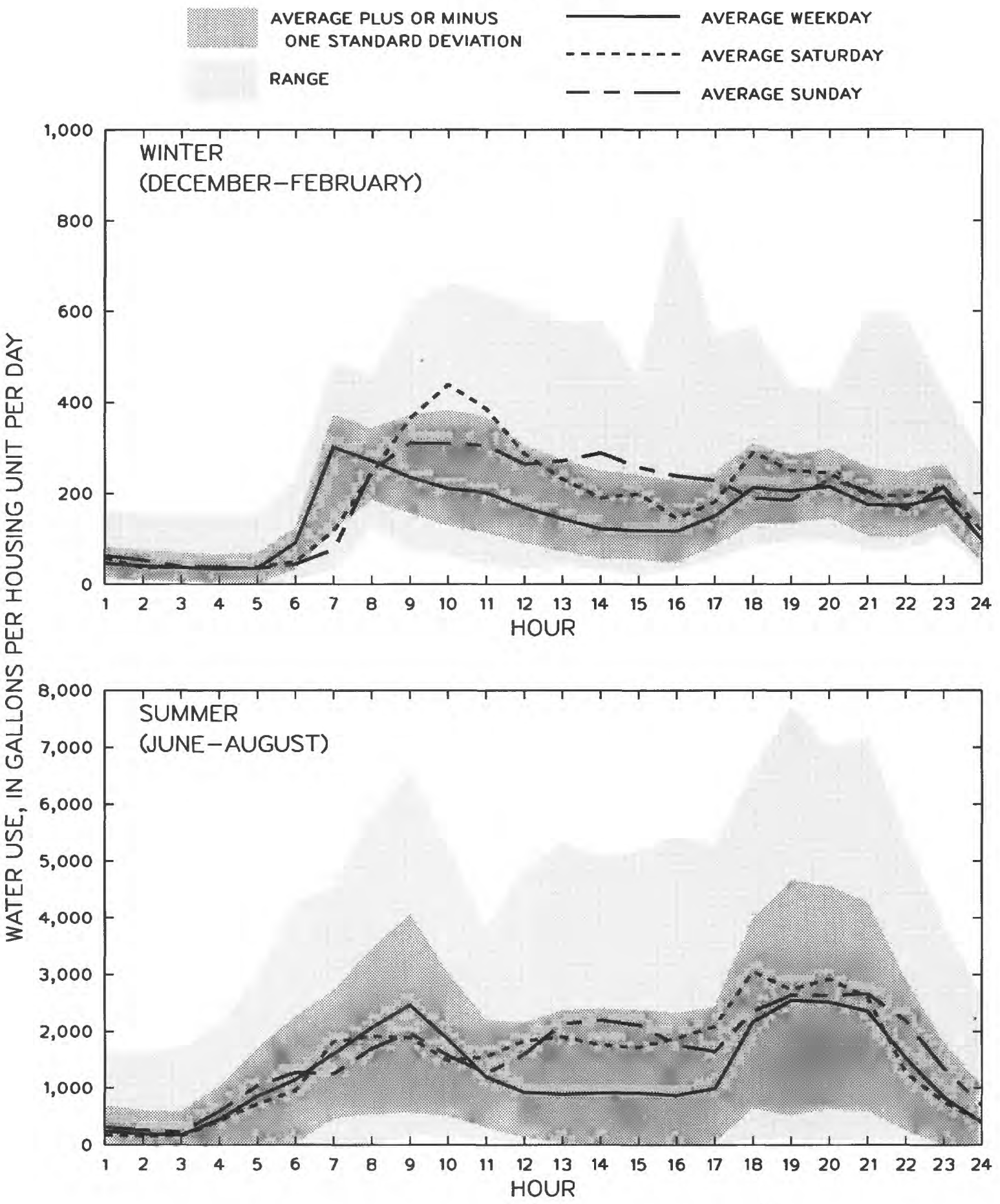

Figure 16.--Hourly water use at site NHG, for winter and summer, September 1986December 1987. 


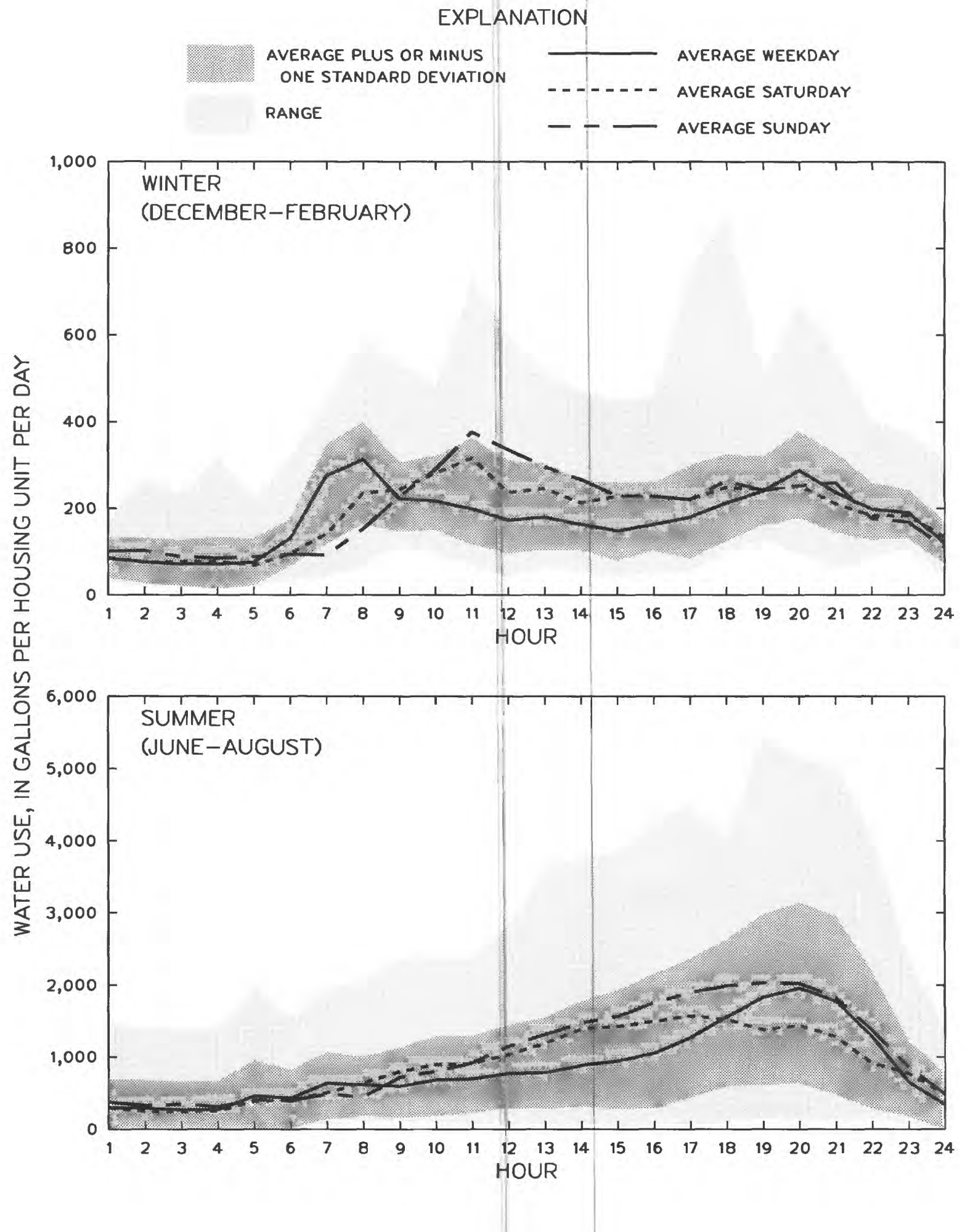

Figure 17.--Hourly water use at site NLG, for winter and summer, August 1986December 1987. 


\section{EXPLANATION}

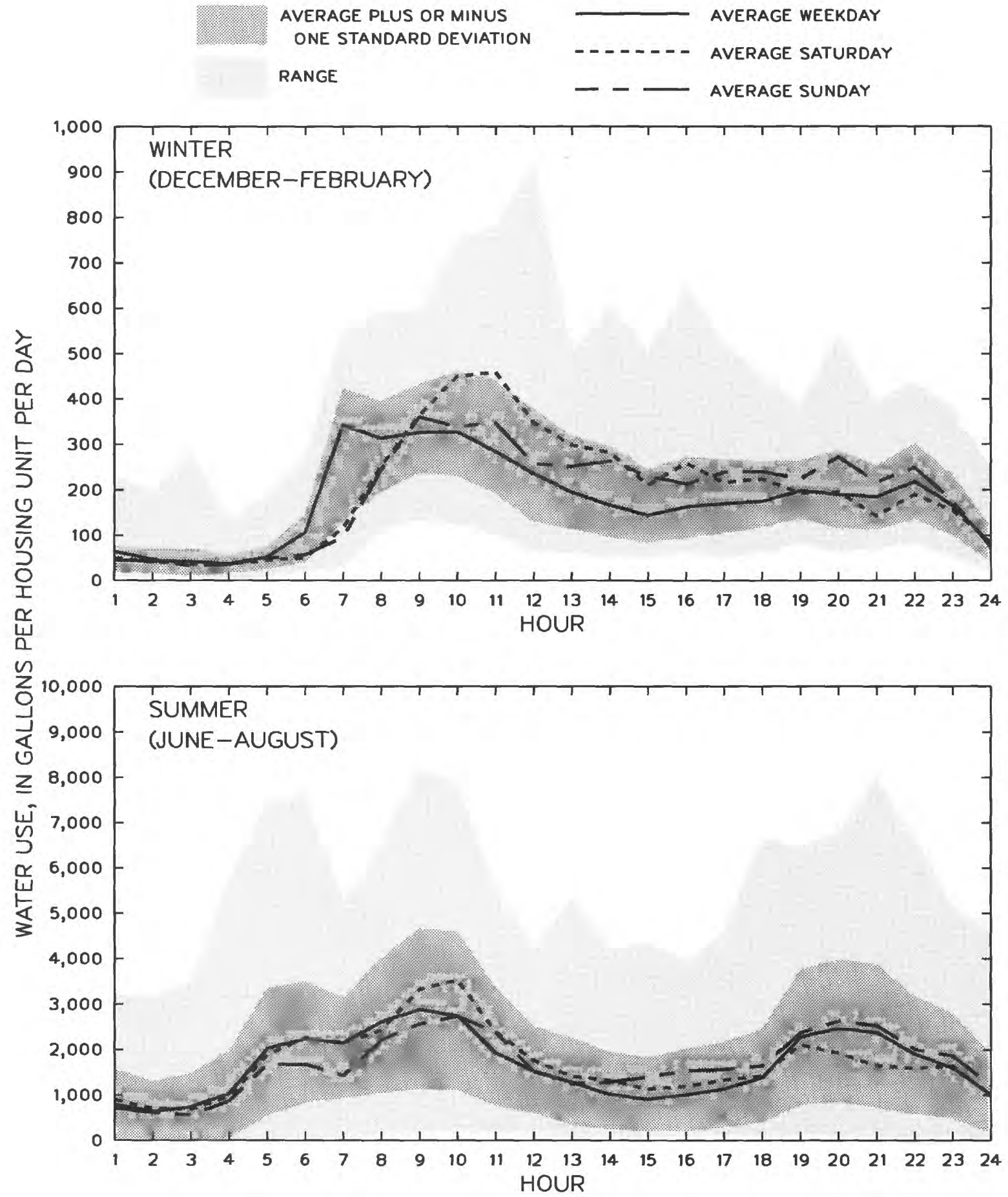

Figure 18.--Hourly water use at site NMG, for winter and summer, June 1986-

December 1987. 


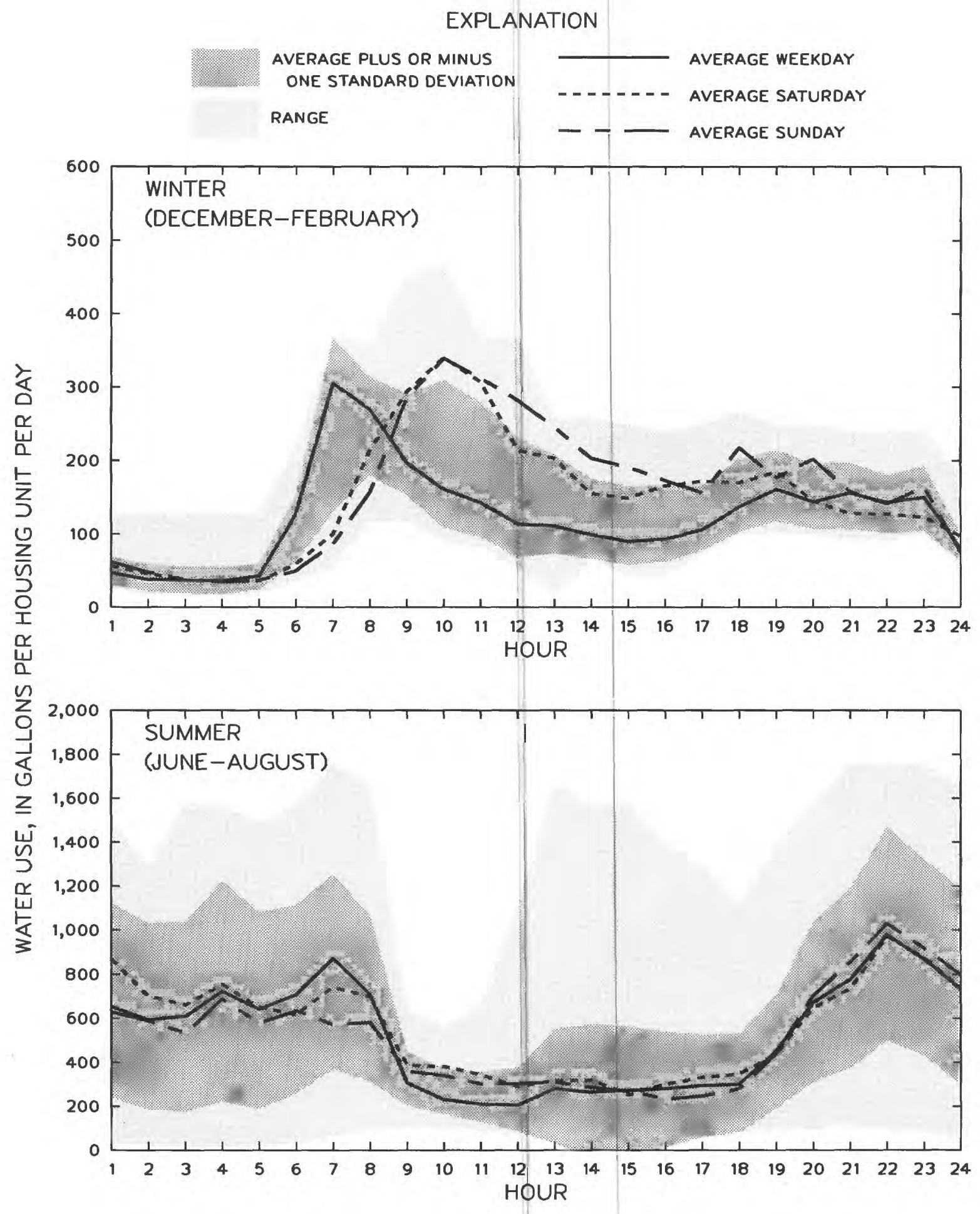

Figure 19.--Hourly water use at site NYH, for winter and summer, January 1987December 1987. 
peak at 2 a.m., due to municipal park lawn watering.

Study site N8P (fig. 11) is unique among study sites because it contains primarily multiunit housing in an urban environment, including large houses remodeled into apartments, high-rise condominiums, and townhouses. This is the largest study site $(3,533$ housing units) but has the smallest lot size per housing unit (500 square feet per housing unit), smallest lawn size (20 square feet per housing unit), and smallest number of persons per housing unit (1.4) (table 1). Lawn size and lot size are difficult to derive for this site because of the large variation in housing types and should be viewed as rough estimates. Data for winter indicate peak water use occurring at 8 a.m. on weekdays and between 10 a.m. and noon on weekends. Summer wateruse patterns for this study site are similar to winter patterns because outside water use is minimal. This study site has the smallest average (163 GUD), smallest maximum daily (239 GUD in 1987), and smallest maximum hourly (412 GUD in 1987) water use (table 2).

Study site NYH (fig. 19) is unique because it consists of a townhouse development containing 261 housing units in a suburban setting. This study site has the second smallest lot size $(2,800$ square feet per housing unit), third smallest lawn size $(2,000$ square feet per housing unit), and second smallest number of persons per housing unit (1.9). Lot size per housing unit was arbitrarily calculated based on the approximate area of a 12-block housing unit. Lawn size per housing unit included a large amount of landscaping in commonlyowned areas of the townhouse development, which was estimated by planimetering the area on aerial photographs. Hourly water-use patterns are very similar to those at site N8P (fig. 11) during the winter, but summer patterns are different; operation of a centrally controlled sprinkler system during the night causes a broad water-use peak from 7 p.m. to 7 a.m. Average water use is larger here than at site N8P, probably due to the larger lawn size and larger number of persons per housing unit.

The remaining 13 sites can be grouped together as suburban, single-family residential. Because of their similarities, hourly wateruse patterns often are similar. In winter, weekday use often shows a peak between 7 a.m. and 9 a.m. (see, for example, fig. 5). A few sites, however, have broader morning wateruse peaks (see, for example, fig. 4) that might be related to the number of people staying at home during the day. A second water-use peak on weekdays during winter occurs from 6 p.m. to 8 p.m. Those sites that show a sharp morning peak usually show a sharp evening peak. In winter, water-use rates are higher on Saturday and Sunday than on weekdays. Although Sunday usually has the highest daily rate, the peak average hourly rate usually occurs on Saturday at 10 or 11 a.m. Variability of hourly use rates generally is large during the day time and small during the nighttime, with the smallest variability often occurring from 4 a.m. to 5 a.m.

Summer water-use patterns at these suburban neighborhoods indicate a continuum of use patterns varying between two extremes--one with a single water-use rate peak and the other bimodal. Hourly water-use patterns for site NLG (fig. 17) are representative of the first of these extremes. Water use increases gradually as the day progresses culminating at 7 or 8 p.m. and then rapidly decreasing. This broad peak probably is representative of manual lawn watering. Hourly water-use patterns for site NBW (fig. 13) are representative of the second extreme in this continuum of use patterns, that of bimodal summer use. Summer use has weekday peaks at 9 a.m. and 8 p.m. The sites in this group tend towards upper-middle class and probably have the largest number of automatic sprinkler systems; preset times of operation on these systems may account for the observed wateruse patterns. However, no inventory of sprinkler systems is available to verify this hypothesis. The number of people at home during the day (who could water the lawn) also may affect whether summer use peaks are 
unimodal or bimodal, but no data were available on the number of persons home during the day.

\section{ANALYSIS OF DATA}

The goal of this analysis of the water-use data is to find methods for estimating average water use, maximum daily water use, and maximum hourly water use. The analysis was done in several steps.

First, methods for estimating average water use are examined by relating 1980-87 weekly water use to site-descriptive variables (table 1). The weekly water-use data are separated into inside water use and outside water use components because each is dependent on different site-descriptive variables. Next, the effect of weather variables and water-conservation programs on outside water use are examined. Finally, methods for estimating maximum daily water use and maximum hourly water use are examined using the 198687 hourly dataset and the site-descriptive variables.

\section{Average Water Use}

It is useful to quantify average water use for managing current water demand, and it is useful to estimate future average water use to design new water-supply structures. Longterm average water use for each study site was calculated from the 1980-87 weekly dataset (table 2). Among site-descriptive variables, average water use correlates best with lot size-the correlation coefficient $(r)$ is 0.82 . Average use also correlates with lawn size $(r=0.77)$ and assessed value $(r=0.74)$. However, since inside and outside water use differ so markedly and are dependent on different factors, more information can be extracted from the data by separating water use into these two components before attempting to derive predictive relations.
Maidment and others (1985, p. 20-24), in a study of water use in nine cities in Texas, Florida, and Pennsylvania, reported that municipal water use could be defined as a function of temperature; during periods of no rainfall, a maximum water use could be defined for each temperature. Departures from this maximum use as a result of precipitation were then modeled on a daily timescale as exponential decay functions beginning on the day when precipitation occurred.

For this study, temperature functions for water use were defined for each study site using the 1980-87 weekly dataset. As was determined in the earlier study (Maidment and others, 1985, p. 20), temperature functions are better defined at the weekly timescale than at the daily or monthly timescales. The temperature variable used here is the average of the maximum daily temperatures for each week; the maximum temperature is thought to be a better indicator of conditions during the daytime, when most water use occurs. It is also a more readily available dataset because it is tabulated by the National Weather Service.

The relation of weekly average water use to weekly average maximum air temperature for site NHG is shown in figure 20. Water use at this study site is relatively small with little variation when temperatures are less than about $60^{\circ} \mathrm{F}$. Above this temperature breakpoint, water use increases with an increase in temperature. The slight nonlinearity of the relation appears to be caused partly by precipitation. When data are separated into classes on the basis of precipitation, linear relations differ for each precipitation class, and the slope of the regression line decreases as precipitation increases (fig. 20).

Temperature-independent and temperature-dependent water use are relatively equivalent to inside water use and outside water use and also are relatively equivalent to winter water use and summer water use. However, this equivalency is not rigorously correct; therefore, for this study, the term "base water 


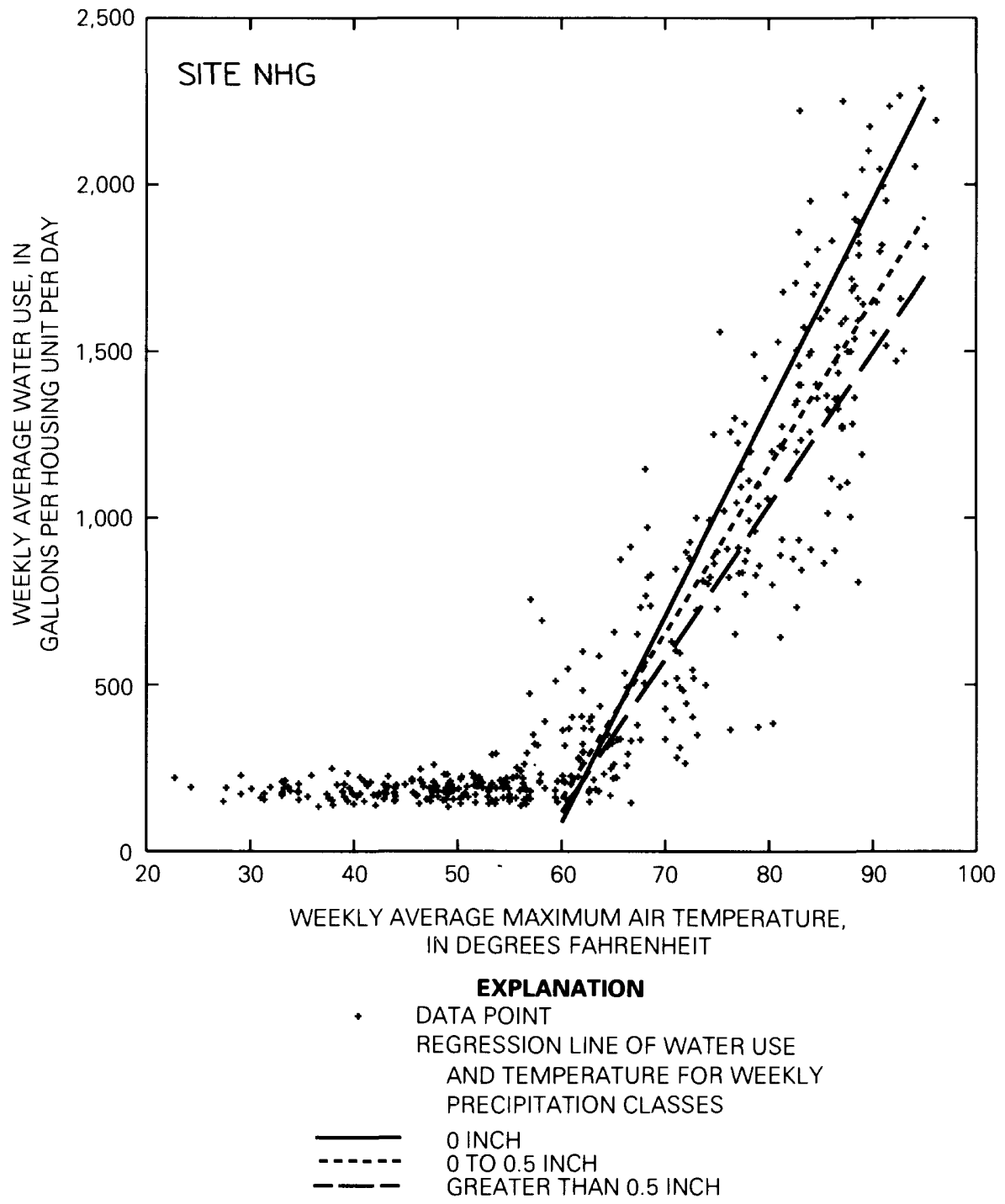

Figure 20.--Relation of weekly average water use to weekly average maximum air temperature for site NHG, 1980-87.

use" will be used to signify the temperatureindependent use, and "seasonal water use" will be used to signify the temperaturedependent use.

A temperature breakpoint was determined for each study site by using nonlinear regression to estimate the four parameters that define the temperature function: Average base water use, temperature breakpoint, and slope and intercept of the seasonal water-use regression line. Initial estimates for these parameters were made using graphic techniques, and nonlinear regression was used to find the optimal fits. Temperature breakpoints estimated in this way ranged among the 16 study sites from 56 to $63^{\circ} \mathrm{F}$. However, average base water use was determined to be relatively insensitive to small changes in the selected breakpoint, and a representative value of $60^{\circ} \mathrm{F}$ was selected for use in this study to separate base water use from seasonal water use.

\section{Base water use}

Base water use, previously defined as temperature-independent water use, was 
quantified by averaging water-use rates for weeks during which the weekly average maximum temperature was less than $60^{\circ} \mathrm{F}$; this condition occurred during 180 weeks throughout the 8-year study period, for an average of 22.5 weeks per year. Among the 16 sites, average base water use ranged from 137 to 307 GUD (table 2). Base water use as a percentage of total water use ranged from 28 to 85 percent, with an average value of 46 percent. Metered sites had an average base use of about 81 gallons per person per day, whereas flat-rate sites averaged about 89 gallons per person per day.

Average base water use also was calculated for each calendar year. The coefficient of variation of the annual averages ranged from 0.05 to 0.18 (table 2). Base water use at some of the sites had small, but statistically significant time trends: Base use at five of the sites rose to a maximum in 1985-86 and then declined; base use at three sites declined throughout 1980-87; base use at two sites increased throughout 1980-87; and base use at six sites had no trends. Because the trends had no common pattern among the 16 sites, and because the trends did not correlate with any of the site-descriptive variables, the trends were not removed from the data.

Among site descriptive variables, base water use correlated best with persons per housing unit. This is contrary to the Johns Hopkins study (Linaweaver and others, 1966, p. 29), which reported home market value to be the most important explanatory variable in predicting inside water use; here the correlation with assessed value was low. Home market value may be less important now due to the ubiquity of the common inside highwater-use appliances.

The relation of base water use to persons per housing unit is shown in figure 21 . For metered sites there was a good linear relation between the variables:

$$
\mathrm{Q}_{b, m}=54+57 \mathrm{PPH}
$$

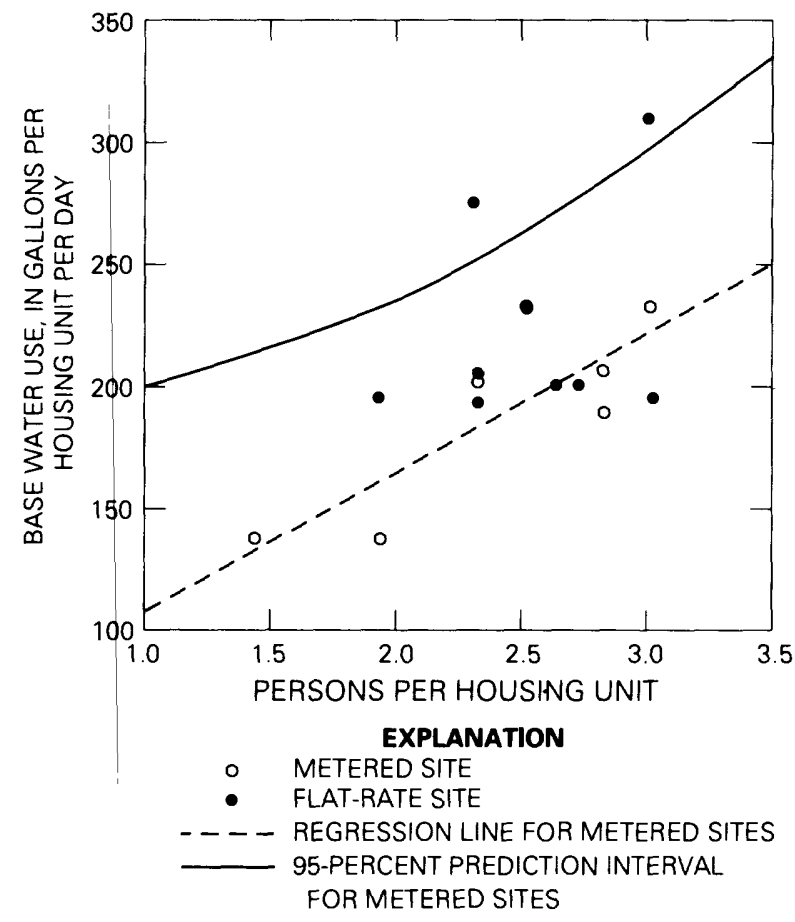

Figure 21.--Relation of base water use to persons per housing unit.

where $Q_{b, m}=$ regression-estimated base use (metered sites), in gallons per housing unit per day; and

$\mathrm{PPH}=$ persons per housing unit.

The coefficient of determination for this relation is 0.70 , and the standard error of the regression slope is 17 . The regression line is indicated as a solid line in figure 21; the dashed line shows the upper 95-percent prediction interval. This relation also is illustrated in Design Graph A, which is discussed in the section "Estimation of Design Parameters."

The relation between base use and persons per housing unit is less predictable at flat-rate 


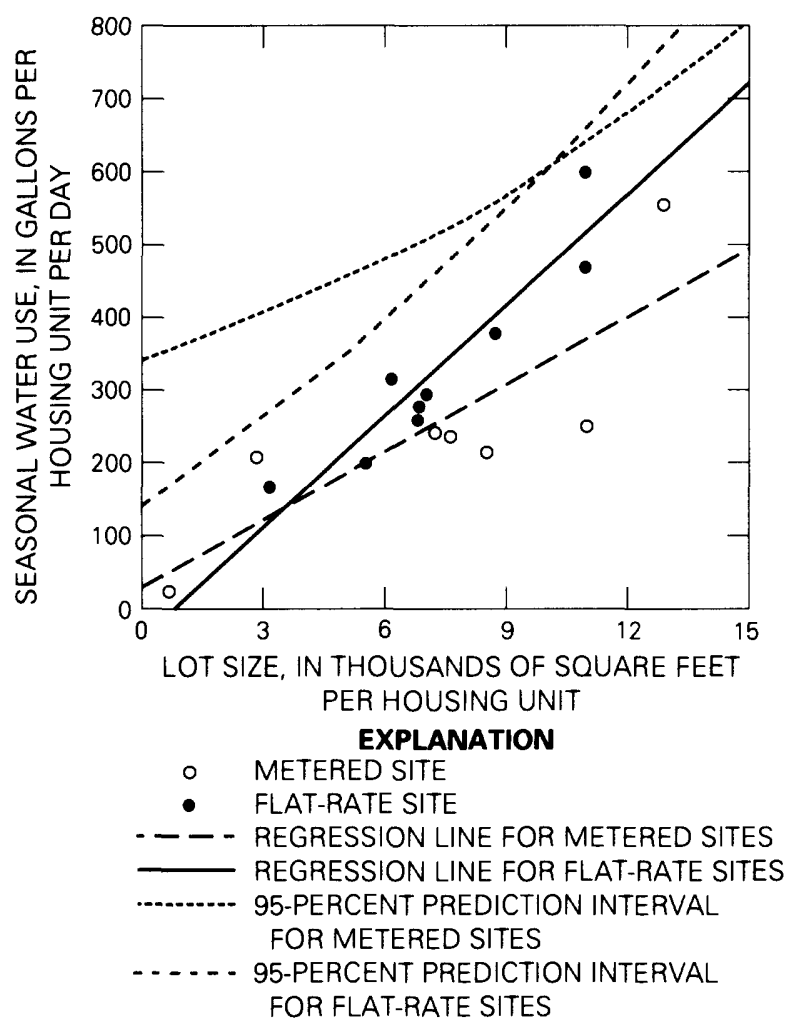

Figure 22.--Relation of seasonal water use to lot size.

For the metered sites, the coefficient of determination is 0.70 , and the standard error of the regression slope is 8.5 . For the flat-rate sites, the coefficient of determination is 0.88 and the standard error of the slope is 6.6. The upper 95-percent prediction interval also is shown in figure 22 for each of these relations. These relations also are illustrated in Design Graphs B and C, which are discussed in the section "Estimation of Design Parameters."

The water-use relations developed thus far have used site-descriptive variables, which are assumed to be static over time. This approach is useful because water-use rates can then be estimated for proposed new housing developments by using design values for these variables (lot size, metered or flat rate, persons per household, which can be estimated based on number of bedrooms and bathrooms). The question arises, however, of the affect of non- static variables such as water-conservation programs and the weather.

Water-conservation programs have been initiated by the Denver Water Department during drought periods since as early as 1922, and are known to be effective in decreasing systemwide water demand (Mary Martin, Denver Water Department, oral commun., 1990). Lawn watering was restricted to every third day from 1980-82, and voluntarily restricted from 1983-87. During 1981, water conservation was particularly stressed through a media campaign that introduced an "ET" (evapotranspiration) program (publicized daily lawn-watering requirements) and xeriscape program (low-water-demand landscaping).

Lawn-watering-season weather at the Denver Airport weather station (DENVER WSFO AP) varied significantly during 1980-87 (table 3). The number of weeks when average daily maximum temperature was more than $60^{\circ} \mathrm{F}$ ranged from 23 to 34 with an average of 29.5; average daily maximum temperature ranged from 74.0 to $80.1^{\circ} \mathrm{F}$ with an average of $77.0^{\circ} \mathrm{F}$; and total precipitation ranged from 6.6 to 14.3 inches with an average of 9.4 inches. These study-period ranges and averages are very similar to those for a 23-year period (196587) for which daily weather data were analyzed (table 3 ). Water-conservationprogram and weather variables were tested as predictor variables (along with lot-size and billing-type variables) in a multiple-regression analysis for annual seasonal water use. A coded water-conservation-program variable was constructed having values ranging from 5 (indicating the presence of strong constraints) to 1 (indicating the presence of relatively weak constraints). Weather variables used were average maximum daily temperature and total precipitation for weeks when average maximum daily temperature was more than $60^{\circ} \mathrm{F}$ (table 3 ). Only lot size and billing type were determined to be significant at an alpha level of 0.05 . Although it is known that waterconservation programs affect water use, their effect cannot be isolated at the annual timescale from among the random and unex- 
sites than at metered sites.. Base water use at seven of the flat-rate sites clusters around a value of 200 GUD (or about 83 gallons per person per day) and is not correlated with persons per housing unit. Base water use at the remaining two flat-rate sites is significantly larger, with an average of about 290 GUD (or about 110 gallons per person per day). Average base water use per person for all the flat-rate sites is about 89 gallons per person per day, with a standard deviation of 17; these statistics need to be used with caution because the data are grouped.

Use of the age-factor variable (ratio of persons over 65 and under 18 years of age to total population) did not improve prediction of base water use. A more direct measurement of persons home during the day, however, might improve estimation methods for base water use.

\section{Seasonal Water Use}

Seasonal water use, previously defined as temperature-dependent water use, was quantified by using data from weeks when weekly average maximum temperature was greater than $60^{\circ} \mathrm{F}$. This temperature breakpoint was exceeded 236 times during 1980-87 for an average of 29.5 weeks per year. These warm weeks can occur at any time during the year, but occur primarily from June through September. Average seasonal use was calculated as follows: (1) An average was taken of water use during the 236 warm weeks; (2) average base water use was subtracted from this average; and (3) seasonal use was annualized by using a coefficient reflecting the proportion of the year during which seasonal use occurred (here $29.5 / 52=0.57$ ). The resulting average seasonal use (table 2) varies from 25 GUD at site N8P to 575 GUD at site N3J.

Average seasonal use for each calendar year also was calculated. Variation from year to year generally is larger than for base water use; coefficients of variation range from 0.08 to 0.31 (table 2); thus, for most sites, the majority of variation in water use from year to year is due to variation in seasonal water use rather than base water use. The annual variation is most likely due to weather. As stated earlier, there were small increases in the cost of water during the study period, but any variation due to these increases cannot be isolated from the more general variability present in the dataset.

Among site descriptive variables, seasonal water use correlated with lot size $(r=0.83)$, lawn size $(r=0.79)$, and assessed value $(r=$ 0.81 ). Multiple regression indicated that assessed value, when combined with billing type, were the best set of explanatory variables. However, lot size and billing type performed only slightly less well, and lot size is a much easier variable to work with because it is easier to quantify and does not change with time as does assessed value. Lawn size was a poorer predictor, and three variables (lot size, lawn size, assessed value) were in themselves correlated, and using combinations of them does not improve the regression significantly. For these reasons, lot size and billing type were selected as explanatory variables. The relation between seasonal water use and lot size is shown in figure 22 . There is more scatter in the data for metered sites than for flat-rate sites. The regression equations for each billing type are:

$$
\begin{gathered}
Q_{s, m}=29+29 L, \text { and } \\
Q_{s, f}=-29+47 L,
\end{gathered}
$$

where $Q_{s, m}=$ regression-estimated seasonal water use (metered sites) in gallons per housing unit per day;

$$
\begin{aligned}
Q_{s, f}= & \text { regression-estimated seasonal } \\
& \text { water use (flat-rate sites) in } \\
& \text { gallons per housing unit per } \\
& \text { day; and }
\end{aligned}
$$

$L=$ lot size, in thousands of square feet per housing unit. 
plained variability in the dataset, possibly because only 8 years of data are available. The effect of weather variables is obscured at an annual timescale. The more that weather variables are aggregated into longer time intervals, the less they reflect the actual conditions under which the decision to water was made. For example, precipitation during cool weather is likely to have less effect on decreasing water use than precipitation during hot weather. A weather variable that integrates the effects of temperature and precipitation at a more representative timescale is likely to correlate better with water use.

One such weather-integrating variable is the modified-Blaney-Criddle crop water requirement. Monthly water requirement can be calculated using this empirical formula, which uses crop-water-requirement coefficients derived from field experiments and extends them to monthly temperature and precipitation conditions (U.S. Soil Conservation Service, 1970). Here, bluegrass waterrequirement coefficients derived from lysimeter experiments in areas near Denver (Borelli and others, 1981, p. 338-339) were used. The monthly water requirements can be summed to an annual requirement, which preserves the weather interactions occurring at the monthly timescale. Calculated annual requirement during the study period ranged from 24 to 35 inches with an average requirement of 28 inches. This range and average are very similar to those for a 23-year period (1965-87) for which weather data were analyzed (table 3).

Blaney-Criddle water requirement was determined to be a significant predictor variable for annual seasonal water use, along with lot size and billing type. Because billing type is important, separate relations were developed for flat rate and metered sites:

$$
\begin{gathered}
Q_{s, m}=-183+29 \mathrm{~L}+7.3 \mathrm{~B} ; \text { and } \\
Q_{s, f}=-314+47 \mathrm{~L}+10 B,
\end{gathered}
$$

where $Q_{s, m}=$ regression-estimated seasonal water use (metered sites) in gallons per housing unit per day;

$$
\begin{gathered}
Q_{s, f}=\begin{array}{l}
\text { regression-estimated seasonal } \\
\text { water use (flat-rate sites) in } \\
\text { gallons per housing unit per } \\
\text { day; }
\end{array} \\
L=\text { lot size, in thousands of square } \\
\text { feet per housing unit; and } \\
B=\text { Blaney-Criddle water } \\
\text { requirement. }
\end{gathered}
$$

For the metered sites, the coefficient of determination is 0.63 , the standard error of the lot-size coefficient is 3.3 , and the standard error of the Blaney-Criddle coefficient is 4.0. For the flat-rate sites, the coefficient of determination is 0.78 , the standard error of the lot-size coefficient is 3.2, and the standard error of the Blaney-Criddle coefficient is 2.1. The relation for metered sites also is illustrated in Design Graphs D and E, which are discussed in the section "Estimation of Design Parameters."

Relations between water use and weather variables also can be developed at the weekly timescale, as discussed earlier (see fig. 20). Because interactions between temperature and precipitation are better preserved at this timescale, relations should be better defined. However, the Blaney-Criddle formula cannot be used to estimate weekly water requirement. The Jensen-Haize or Penman equations (Jensen and others, 1990) can be used, but these require additional information about solar radiation and wind. At the daily timescale, the relation between water use and weather variables deteriorates, and autocorrelation in the data becomes a problem because lawnwatering use patterns on a given day are affected by what happened on the previous day. 
Table 3.--Lawn-watering-season weather statistics, Denver Airport weather station [F, degrees Fahrenheit; lawn-watering season is defined as all weeks when average daily maximum temperature is greater than $60^{\circ} \mathrm{F}$ ]

\begin{tabular}{|c|c|c|c|c|}
\hline Year & $\begin{array}{l}\text { Number of } \\
\text { weeks in } \\
\text { season }\end{array}$ & $\begin{array}{c}\text { Average } \\
\text { maximum } \\
\text { temperature, } \\
\text { in }{ }^{\circ} \mathrm{F} \\
\end{array}$ & $\begin{array}{l}\text { Total } \\
\text { precipitation, } \\
\text { in inches }\end{array}$ & $\begin{array}{l}\text { Blaney-Criddle } \\
\text { lawn-watering } \\
\text { requirement, in inches }\end{array}$ \\
\hline 1965 & 32 & 74.4 & 16.4 & 22 \\
\hline 1966 & 33 & 76.7 & 7.7 & 29 \\
\hline 1967 & 33 & 73.1 & 18.5 & 20 \\
\hline 1968 & 29 & 76.6 & 6.4 & 25 \\
\hline 1969 & 27 & 77.6 & 16.6 & 23 \\
\hline 1970 & 28 & 77.4 & 9.9 & 24 \\
\hline 1971 & 31 & 76.2 & 5.3 & 27 \\
\hline 1972 & 32 & 76.2 & 9.4 & 27 \\
\hline 1973 & 28 & 77.5 & 9.6 & 24 \\
\hline 1974 & 31 & 78.2 & 7.6 & 30 \\
\hline 1975 & 31 & 75.7 & 12.3 & 24 \\
\hline 1976 & 31 & 75.4 & 10.0 & 26 \\
\hline 1977 & 31 & 78.3 & 6.8 & 33 \\
\hline 1978 & 30 & 77.9 & 6.0 & 30 \\
\hline 1979 & 27 & 78.5 & 13.3 & 25 \\
\hline 1980 & 30 & 78.6 & 8.8 & 30 \\
\hline 1981 & 34 & 76.5 & 8.3 & 35 \\
\hline 1982 & 30 & 74.0 & 9.0 & 25 \\
\hline 1983 & 27 & 77.2 & 9.0 & 24 \\
\hline 1984 & 23 & 80.1 & 9.8 & 24 \\
\hline 1985 & 28 & 77.5 & 9.7 & 27 \\
\hline 1986 & 32 & 75.6 & 6.6 & 31 \\
\hline 1987 & 32 & 76.7 & 14.3 & 28 \\
\hline Average & 30.0 & 76.8 & 10.1 & 27 \\
\hline $\begin{array}{l}\text { Range } \\
(1965-87)\end{array}$ & 23-34 & $73.1-80.1$ & $5.3-18.5$ & $20-35$ \\
\hline Average & 29.5 & 77.0 & 9.4 & 28 \\
\hline $\begin{array}{l}\text { Range } \\
(1980-87)\end{array}$ & 23-34 & $74.0-80.1$ & $6.6-14.3$ & $24-35$ \\
\hline
\end{tabular}




\section{Maximum Daily Water Use}

It is useful to quantify maximum daily water use for manaing current water demand, and it is useful to estimate future maximum daily water use to design new drinking-water-treatment-plant capacity. Maximum daily use can be calculated from the hourly dataset obtained from June 1986 through December 1987. At seven of the sites, hourly data collection did not begin until July 1986 or later, and possibly the 1986 peak use was missed. As noted earlier, maximum daily use is not available from sites NAC and NYH because of partially unrecorded water. Therefore, maximum daily use is reported at 9 of the sites for 1986 and at 14 sites for 1987. These data and the ratio of maximum daily use to average use are listed in table 2. Maximum daily use ranged from 239 GUD (1.51 times average use) at site N8P in 1987 to 3,603 GUD (6.29 times average use) at site NHG in 1987.

Among the site-descriptive variables, maximum daily water use correlates best with lot size $(r=0.92)$, lawn size $(r=0.93)$, and assessed value $(r=0.79)$. Among these, the most easily obtained variable is lot size. The relation of maximum daily water use to lot size is shown in figure 23. The best fit line for this relation has the equation:

$$
Q_{\text {max day }}=235+226 \mathrm{~L},
$$

where $Q_{\text {max day }}=$ regression-estimated maximum daily water use, in gallons per housing unit per day; and

$L=$ lot size, in thousands of square feet per housing unit.

This regression has a coefficient of determination of 0.85 , and the standard error of the coefficient is 21 . This relation also is illustrated in Design Graph F, which is discussed in the section "Estimation of Design Parameters."

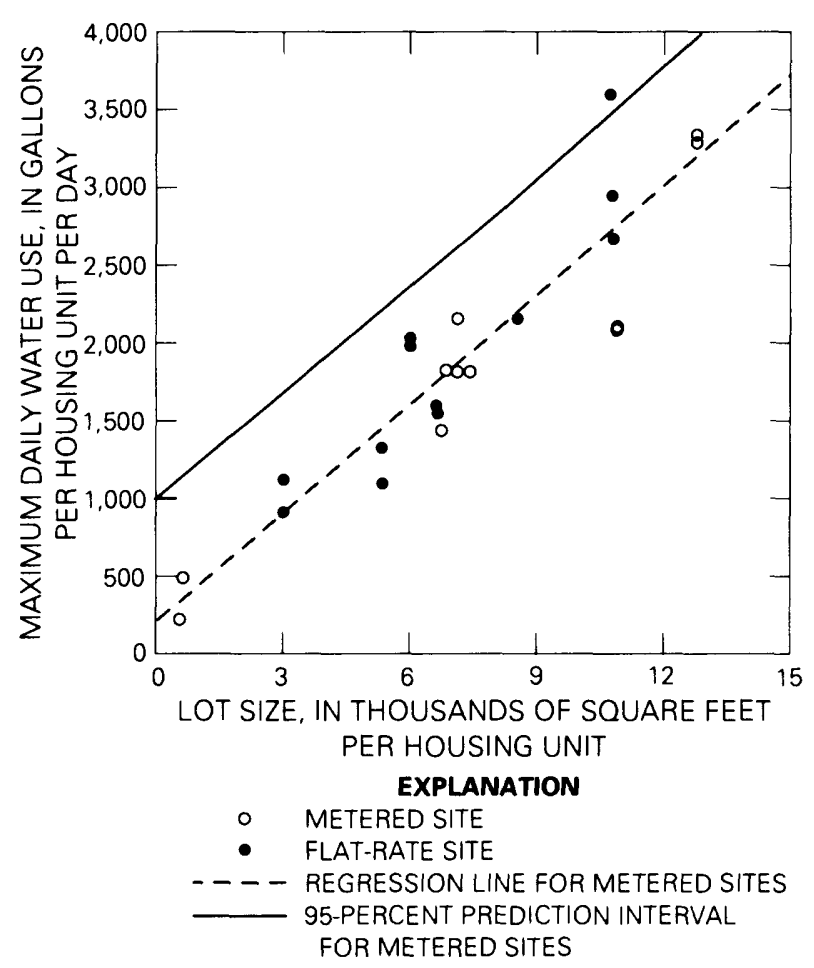

\section{Figure 23.--Relation of maximum daily water use to lot size.}

\section{Maximum Hourly Water Use}

It is useful to quantify maximum hourly water use for managing current water demand, and it is useful to estimate future maximum hourly water use to design new water-transmission lines. Maximum hourly use can be calculated from the hourly dataset obtained from June 1986 through December 1987. At seven of the sites, hourly data collection did not begin until July 1986 or later, and it is possible that the maximum hourly use was missed in 1986. As noted earlier, maximum hourly use is not available from sites NAC and NYH because of partially unrecorded water. Therefore, maximum hourly use is reported at 9 of the sites for 1986 and at 14 sites for 1987. These data and the ratio of maximum hourly use to average daily use are listed in table 2 . Maximum hourly use ranged from 412 GUD (2.61 times average daily use) at site N8P in 1987 to 8,191 GUD (9.75 times average daily use) at site NMG in 1986. 
Among the site-descriptive variables, maximum hourly water use correlates best with lot size $(r=0.95)$, lawn size $(r=0.96)$, and assessed value $(r=0.73)$. Additionally, maximum hourly water use was determined to be inversely correlated to the number of housing units $(r=0.69)$. Among these, lot size and number of housing units are most easily obtained. The relation of maximum hourly water use to lot size is shown in figure 24 . Study sites with a smaller number of housing units have relatively larger maximum hourly water use. The best fit line for this relation with number of housing units included has the equation:

$$
Q_{\max \text { hour }}=21+506 L+30,368 n^{-1} \text {, }
$$

where $Q_{\max }$ hour $=$ regression-estimated maximum hourly water use, in gallons per housing unit per day;

$L=$ lot size, in thousands of square feet per housing unit; and

$$
n=\text { number of housing units. }
$$

This regression has a coefficient of determination of 0.96 , the standard error of the lot size coefficient is 33 , and the standard error of the number of housing units coefficient is 5,398. Billing type is not a significant variable at the $a=0.05$ level when introduced into this regression. This relation also is illustrated in Design Graphs $G$ and $H$, which are discussed in the section "Estimation of Design Parameters."

The significance of the number of housing units to maximum hourly water use is expected based on probability theory. Specifically, if hourly water use is modeled using binomial probability theory, the theory predicts that relative variability of hourly water use will decrease as the number of housing units increases. The net effect is that study sites with a smaller number of housing units have relatively larger maximum hourly

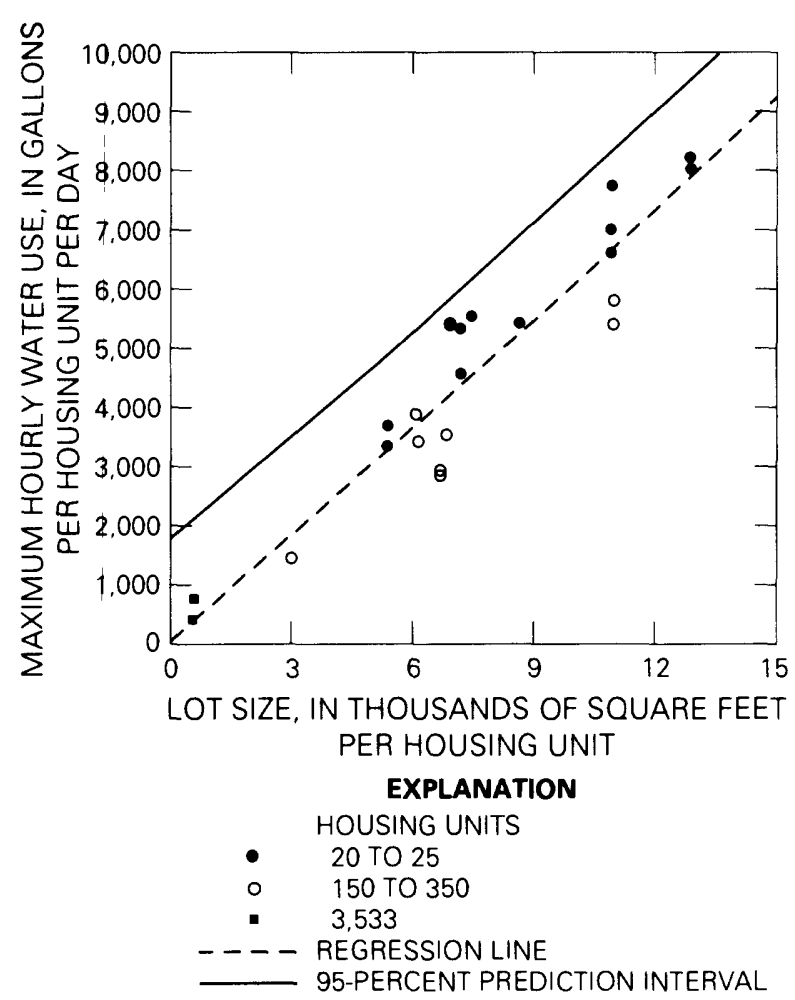

Figure 24.--Relation of maximum hourly water use to Iot size.

water use per unit. This can be verified in a general way by observing that maximumhourly-to-average-use ratios get larger as the number of housing units gets smaller (table 2).

Probability theory also predicts that maximum daily and maximum hourly water use should be related. Linaweaver and others (1966, p. 44) used maximum daily use as a predictor variable for maximum hourly water use:

$$
Q_{\max \text { hour }}=334+2.02 Q_{\max \operatorname{day}(m)},
$$

where $Q_{\max \text { hour }}=$ regression-estimated maximum hourly water use, in gallons per housing unit per day; and 
$Q_{\text {max day }(m)}=$ measured maximum daily water use, in gallons per housing unit per day.

Data from this study produced a similar relation:

$$
Q_{\max \text { hour }}=221+2.28 Q_{\max d a y(m)}
$$

This regression has a coefficient of determination of 0.81 and the standard error of the coefficient is 0.24 . Billing type is a significant predictor variable when added to the regression. The relation between maximum daily and maximum hourly water use is not surprising because both are related to the likelihood of simultaneous water use at many housing units within a study site.

\section{ESTIMATION OF DESIGN PARAMETERS}

The regression equations presented in the preceding sections can be used to estimate the three principal water-use design parameters: Average water use, maximum daily water use, and maximum hourly water use. However, these equations are valid only when predictor variables have values within the ranges presented in this study.

An example calculation of design parameters is presented in table 4 . This example calculation makes use of design graphs modified from previous figures; these design graphs are presented at the back of this report. To ensure that prediction intervals shown on the design graphs are valid, regression assumptions were verified for each equation given. Many of the regressions were developed based on a small number of data points; therefore, prediction intervals are large. When the number of data points was small, apparent outliers were not removed even if a single point had a large effect on regression parameters.

In the example calculation, a proposed residential site is to be metered and estimates of the average number of persons per household and housing unit lot size are given. Average water use is estimated from its base and seasonal components. Design Graph A (p. 62) is used to estimate base water use and the 99percent prediction interval value for base water use. Seasonal water use and the 99percent prediction interval value for seasonal use are estimated based on the given lot size by using Design Graph B (p. 63). Design Graph C (p. 64) would be used to estimate seasonal water use if the proposed residential site were to have flat-rate billing. Total water use is estimated by adding together the base and seasonal water-use values.

Alternatively, seasonal water use could be determined based on lot size and a BlaneyCriddle water requirement. An exceedence value for water requirement can be selected from a quantile plot of water-requirement calculated for 1965-87 (fig. 25). For example, from figure 25 , it can be estimated that the 0.95 quantile for Blaney-Criddle water requirement is about 35 inches; that is, a requirement of 35 inches or more should only occur in 5 years out of 100 . This might reflect a possible drought scenario for the Denver area. Seasonal water use and the 99-percent prediction interval value for seasonal use are estimated by using Design Graphs D and E (p. 65-66). The 99percent prediction interval for seasonal use calculated in this way is slightly less than that calculated using lot size alone. This difference is because prediction intervals are larger in Design Graph B because the relation was developed based on 7 data points whereas the prediction intervals in Design Graph E were developed based on 49 data points. This comparison supports the earlier observation that variability in seasonal water use due to weather is no larger than unexplained variability. This relative insensitivity to weather may be due to the nature of the Denver area's semiarid continental climate: summers are hot with sparse rainfall, and lawns are irrigated frequently. This insensitivity does not mean that seasonal differences are unimportant to a water supplier; the largest calculated BlaneyCriddle water requirement is 46 percent 
Table 4.--Example of residential water-use design calculations

$[\cdots$, not applicable $]$

Proposed site characteristics:

Number of housing units: 200

Housing unit lot size: 8,000 square feet

Projected number of persons per housing unit: 2.5

Billing type: metered

Design tolerance: 1:100 (99-percent prediction interval)

ESTIMATION OF WATER USE

Base water use:

Average limit

Site is to be metered, so obtain average base water

use and 99-percent prediction interval value from

Design Graph A using persons per housing unit

value of 2.5.

Seasonal water use:

Site is to be metered, so obtain average seasonal water use and 99-percent prediction interval value from

Design Graph B using 8,000 square-feet lot size. 275

TOTAL WATER USE, IN GALLONS PER HOUSING UNIT PER DAY: $\quad 470 \quad 930$

Maximum daily water use:

Obtain maximum daily water use and 99-percent prediction

interval value for maximum daily water use from

Design Graph F using 8,000 square-feet lot size.

MAXIMUM DAILY WATER USE, IN GALLONS PER HOUSING UNIT PER DAY:

MAXIMUM DAILY USE/AVERAGE WATER USE RATIO:

Maximum hourly water use:

Obtain maximum hourly water use from Design Graph G using 8,000 square-feet lot size and 200 housing units.

Similarly, read 99-percent prediction interval value for maximum hourly water use from Design Graph $\mathrm{H}$.

MAXIMUM HOURLY WATER USE, IN GALLONS PER HOUSING UNIT PER DAY: 
greater than the smallest Blaney-Criddle water requirement. However, the effects of a prolonged drought on seasonal water use are difficult to model. It is likely that institutional constraints such as mandatory lawn-watering restrictions would affect water-use patterns during such a drought.

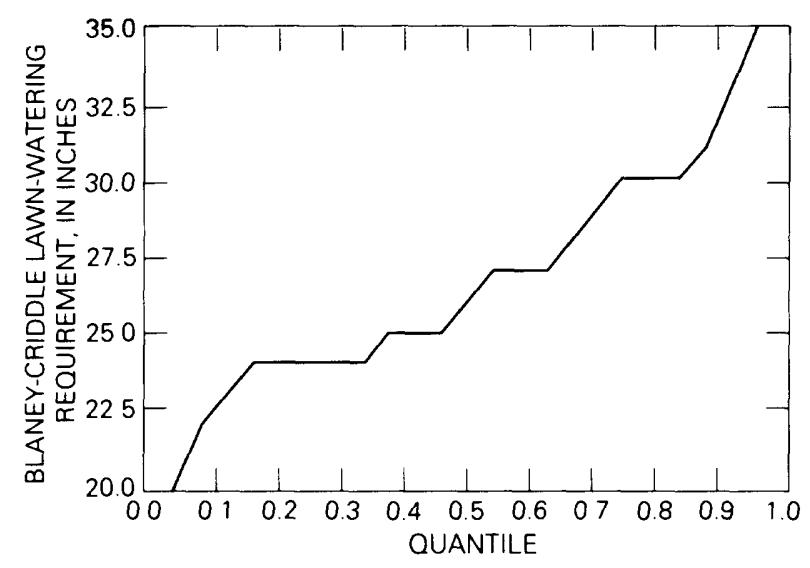

Figure 25.--Quantiles for Blaney-Criddle lawn-watering requirement, 1965-87.

Maximum daily water use and the 99percent prediction interval value for maximum daily use are estimated based on the given lot size by using Design Graph F (p. 67). Maximum hourly water use is estimated based on lot size and the number of housing units by using Design Graph G (p. 68); this graph has a family of curves for different values of number of housing units. The 99-percent prediction interval value for maximum hourly water use is similarly determined from Design Graph $\mathrm{H}$ (p. 69).

When estimating design values for maximum hourly water use, consideration also needs to be given to fire flow requirements. In the Denver metropolitan area, it is common for fire departments to request fire flows of about 1,000 gallons per minute. This rate is equivalent to an hourly flow of 2,400 GUD in a study site of 25 housing units and 200 GUD in a study site of 300 housing units.
In the smaller study sites where maximum hourly use might otherwise be about 5,000 GUD, a decision is needed whether this magnitude of additional demand might affect water pressures enough such that the design value needs to be correspondingly increased.

\section{SUMMARY}

Residential water-use data for 16 study sites in the City and County of Denver are described and analyzed. The dataset consists of weekly water-use data from 1980 through 1987, and hourly water-use data during varying periods among the 16 sites beginning in June 1986 through December 1987.

The data were separated into temperatureindependent (base) water use and temperature-dependent (seasonal) water use by using nonlinear regression; the temperature breakpoint separating these two types of water use occurs on the average at a daily maximum temperature of $60^{\circ} \mathrm{F}$. Base water use is approximately equivalent to inside water use. Among study sites, average base water use ranged from 137 to 307 gallons per person per day. Base water use as a percentage of total water use ranged from 28 to 85 percent, with an average value of 46 percent. Metered sites had an average base use of 81 gallons per person per day, whereas flat-rate sites averaged 89 gallons per person per day. For metered sites, base water use was linearly related to persons per household.

Seasonal water use is approximately equivalent to outside water use. Among study sites, average seasonal water use ranged from 25 GUD to 575 GUD. Linear relations were developed for estimating seasonal water use based on lot size and billing type; flat-rate sites used more water relative to lot size than did metered sites.

Annual variability in average water use was relatively small, with coefficients of variation for annual means ranging from 0.04 to 0.18 . Most of the annual variability can be 
attributed to seasonal water use. Variability in seasonal water use due to weather differences during the study period was no greater than variability due to other causes, including differences in lot and lawn sizes, metering type, and institutional constraints. In addition, mean values and ranges for temperature, precipitation, and theoretical seasonal demand during the 8-year study period (1980-87) were similar to means and ranges during a 23-year period (1965-87). Therefore, relations developed from the study dataset for estimating seasonal water use based on lot size probably are applicable over the long term. A relation was developed for estimating weekly seasonal water use based on lot size and Blaney-Criddle water requirement for bluegrass. Water use during hypothetical extreme weather conditions could be estimated using this relation. However, changes in water use are likely during extreme weather conditions, especially when stimulated by institutional constraints such as mandatory lawn-watering restrictions.

Maximum daily water use ranged from 239 GUD (1.51 times average use) to 3,603 GUD (6.29 times average use). Daily base water use is significantly larger on Saturdays, Sundays, and Mondays than on other days, but annual maximums occur during summer due to seasonal demands that are weather related. Maximum daily water use can be estimated using a linear relation with lot size.

Maximum hourly water use ranged from 412 GUD (2.61 times average daily use) to 8,191 GUD (9.75 times average daily use). Hourly base water use has peaks from 7 a.m. to 9 a.m. and from 6 p.m. to 8 p.m. Hourly seasonal water use varies between two extremes, the first showing a single peak with a maximum around 8 p.m., and the second showing two peaks, one in the morning and one in the evening. Maximum hourly water use can be estimated using a regression equation containing lot size and number of housing units as explanatory variables.

Design graphs were developed for estimation of average water use, maximum daily water use and maximum hourly water use. Average values and 99-percent prediction interval values can be obtained from these graphs. An example problem is presented to illustrate the use of these design graphs.

\section{REFERENCES CITED}

Borrelli, John, Pochop, L.O., Kneebone, W.R., Pepper, I.L., Danielson, R.E., Hart, W.E., and Youngner, V.B., 1981, Blaney-Criddle coefficients for western turf grasses: American Society of Civil Engineering Journal of the Irrigation and Drainage Division, v. 107, no. 1R4, p. 333-341.

Jensen, M.E., Burman, R.D., and Allen, R.G., eds., 1990, Evaporation and irrigation water requirements: American Society of Civil Engineering Manuals and Reports on Engineering Practice No. 70, 332 p.

Linaweaver, F.P. Jr., Geyer, J.C., and Wolff, J.B., 1966, Residential water use--Final and summary report on the residential water use research project: Baltimore, Md., Johns Hopkins University Report V, Phase 2, $1 \mathrm{v}$.

Litke, D.W., and Appel, C.L., 1989, Estimated use of water in Colorado, 1985: U.S. Geological Survey Water-Resources Investigations Report 88-4101, 157 p.

Maidment, D.R., Miaou, Shaw-Pin, Nvule, D.N., and Buchberger, S.G., 1985, Analysis of daily water use in nine cities: Austin, Tex., University of Texas Center for Research in Water Resources Paper CRWR 201, 67 p.

U.S. Army Corps of Engineers, 1986, Future water demands, Appendix 2--Metropolitan Denver water supply systemwide draft environmental impact statement: Omaha, Neb., 290 p.

U.S. Soil Conservation Service, 1970, Irrigation water requirements (revised): Washington, D.C., Technical Release No. 21, $88 \mathrm{p}$. 
SUPPLEMENTAL INFORMATION 


\section{Site E48 (48th Avenue and Eaton Street)}

This study site contains 20 small brick bilevel houses, 3 of which have basement apartments. The lots are small with modest but well-kept landscaping. There is little variation in house size or model type; all were built between 1952 and 1954. There are no parks or nonresidential water users in this study site. This is a paired site with site G52. The water taps are 5/8-inch diameter, service lines are $3 / 4$-inch diameter, and nominal water pressure is 95 pounds per square inch.

The study site water meter is a 3-inchdiameter Hersey with two registers. The minimum recordable flow is 10 gallons.

Weekly data were collected from 1980-87 (416 weekly observations); 3 percent of these data are estimates. Hourly data were collected from June 1, 1986, through December 31, 1987 (13,896 hourly observations); 9 percent of these data are estimates.

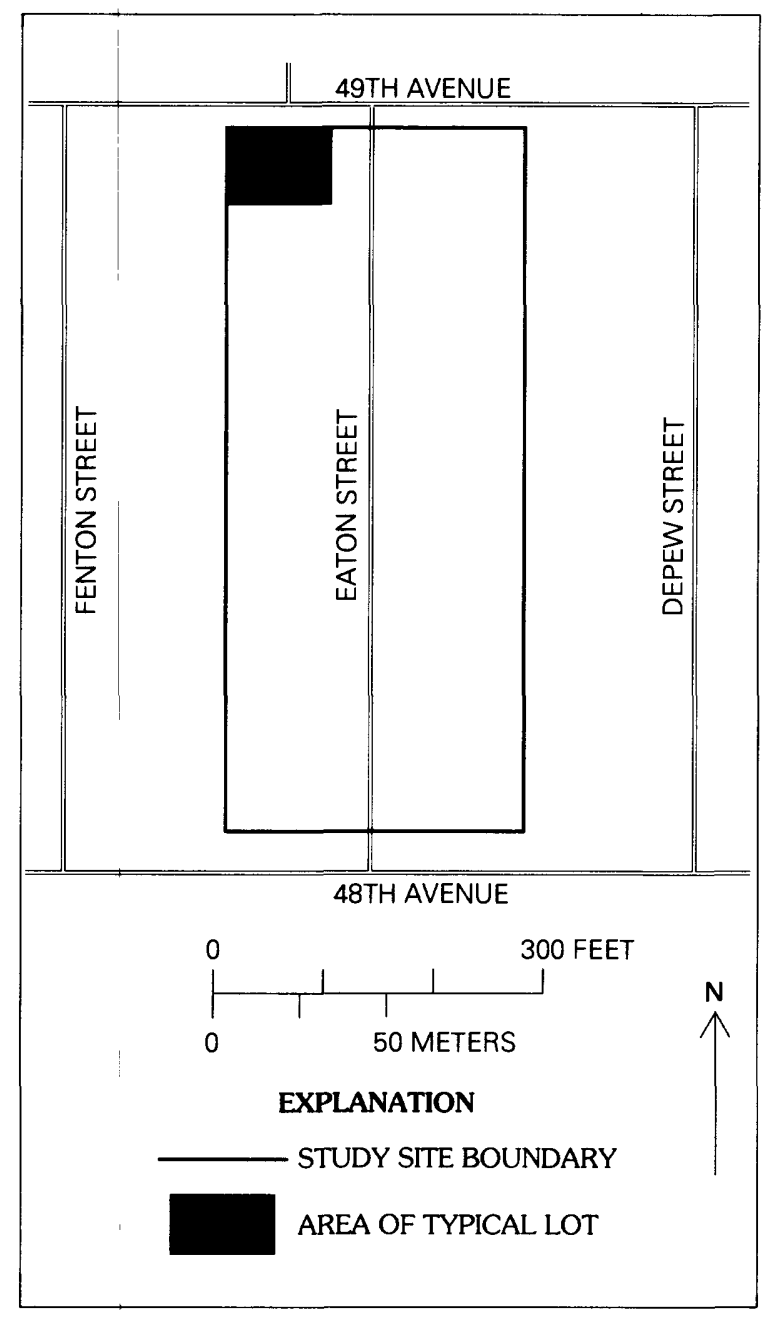




\section{Site G11 (11th Avenue and Glencoe Street)}

This study site contains small brick onestory houses with basements. All houses (169 total) are single-family residences. Some properties include an adjacent vacant lot, and variation in lot size is large. Houses were built during a lengthy period (1904-68) so models vary considerably; the number of bedrooms varies from one to six, and the number of bathrooms varies from one to three. Some lots have driveways in front, but others have a detached garage in the rear, with access from the alley. There are no parks or nonresidential water users in this site. The water taps are mostly 3/4-inch diameter, service lines are 3/4-inch diameter, and nominal water pressure is 90 pounds per square inch.

The study site water meter is a 6-inchdiameter Badger Compound with two registers. Minimum recordable flow is 0.08 gallon.

Hourly data were collected from Summer 1963 to September 1965 as part of the Johns Hopkins study (Linaweaver and others, 1966). Miscellaneous measurements were made from 1966 through 1979 . Weekly data were collected from 1980-87 (416 weekly observations); 6 percent of these data are estimates. Hourly data were collected from July 1, 1986, through December 31, 1987 (13,176 hourly observations); 6 percent of these data are estimates.

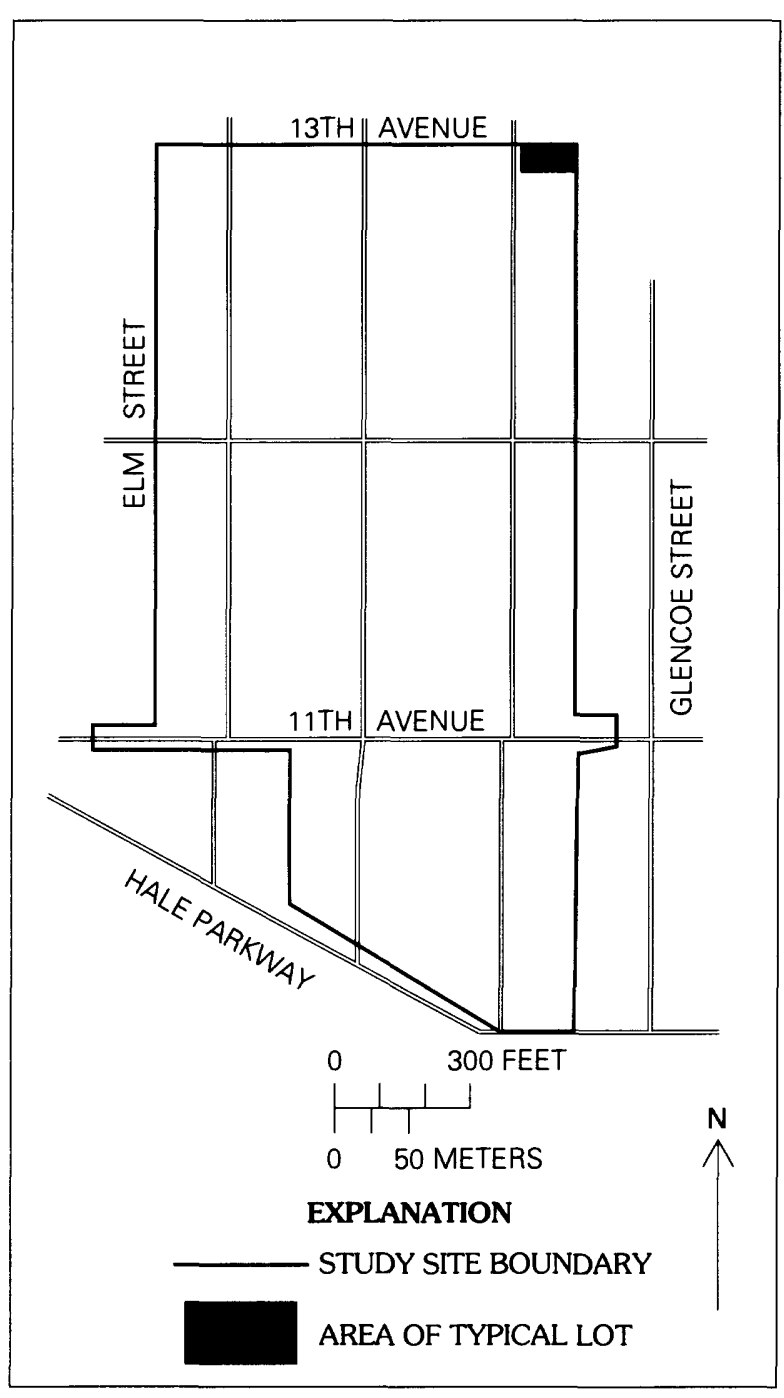




\section{Site G52 (52nd Avenue and Gray Street)}

This study site contains small brick onestory houses with basements on large lots. One duplex and 19 single-family houses make a total of 20 housing units. There is little variation in house size or model type, and all were built between 1960 and 1962. There were no original garages, but many houses have attached carports. Many lots continue into the flood plain of Clear Creek and are partially unused, so average lot size has been adjusted to include only usable parts. Lawns are well kept, but large areas of lots are not landscaped. There are no parks or nonresidential water users in this study site. This is a paired site with site E48. The water taps are 5/8-inch diameter, service lines are 3/4-inch diameter, and nominal water pressure is 100 pounds per square inch.

The study site water meter is a 3-inchdiameter Hersey model CT with two registers. Minimum recordable flow is 10 gallons.

Weekly data were collected from 1980-87, except for missing record from June through September 1983 (390 weekly observations); 6 percent of these data are estimates. Hourly data were collected from June 1, 1986, through December 31, 1987 (13,896 hourly observations); 7 percent of these data are estimates.

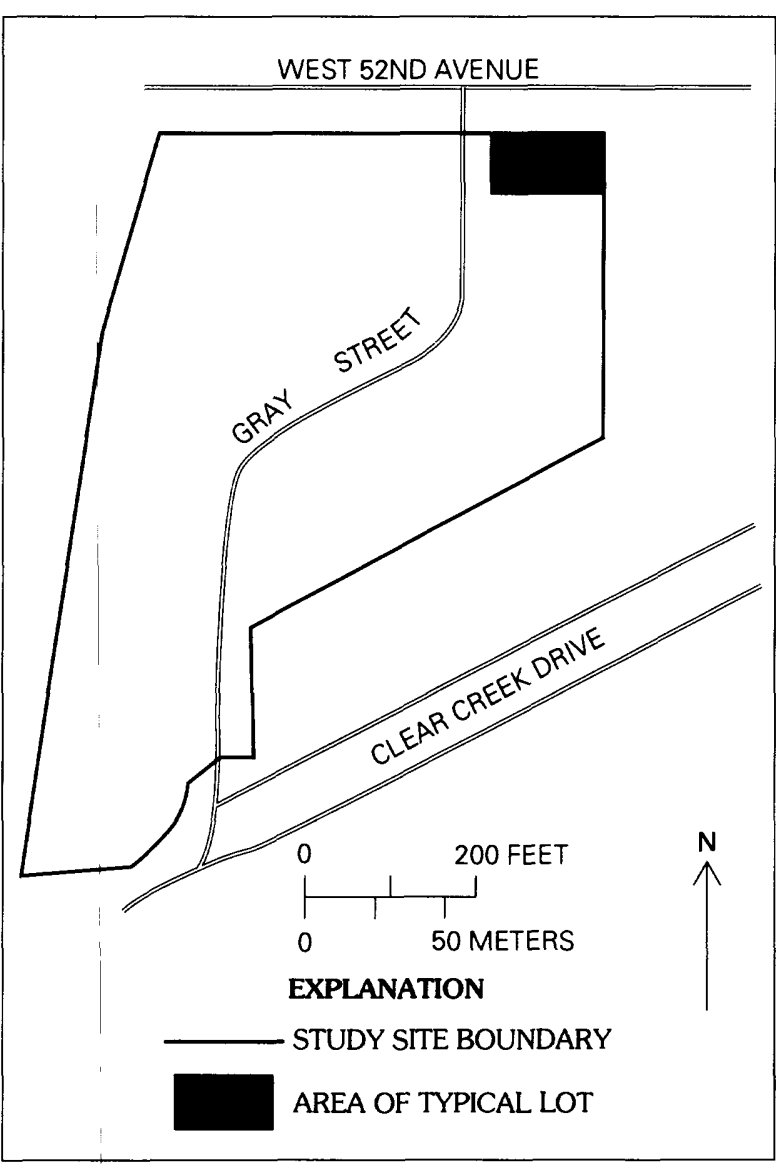




\section{Site H29 (29th Avenue and Humboldt}

\section{Street)}

This study site contains two-story brick houses with basements but few garages on small lots, in an urban setting. There are some multistory, multifamily buildings. There is a large variety in model types, built between 1873 and 1976. Lawns are small and landscaping is minimal. Several commercial buildings are in this study site, and there are three irrigated city parks. The water taps are a mixture of 5/8-inch diameter and 3/4-inch diameter, service lines are mostly $3 / 4$-inch diameter, and nominal water pressure is 75 pounds per square inch.

The study site water meter is a 6-inchdiameter Badger Compound with two registers. Minimum recordable flow is 0.05 gallon.

Hourly data were collected from April 1965 to September 1965 as part of the Johns Hopkins study (Linaweaver and others, 1966). Miscellaneous measurements were made from 1966 through 1979 . Weekly data were collected from 1980-87 (416 weekly observations); 6 percent of these data are estimates. Hourly data were collected from June 1, 1986, through December 31, 1987 (13,896 hourly observations); 3 percent of these data are estimates.

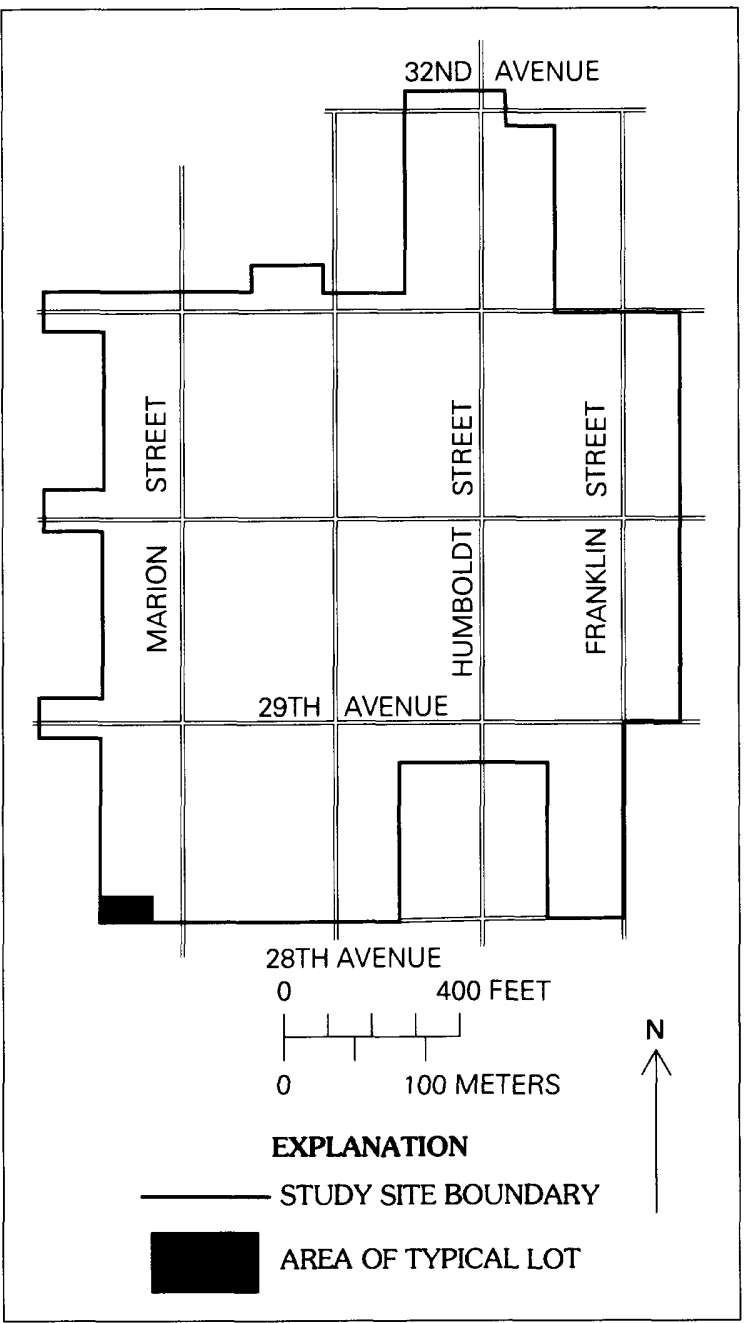


Site M47 (47th Avenue and Milwaukee Street)

This study site contains one-story houses without basements, built between 1886 and 1964. There is a large variety in model types. Eighteen structures are multifamily housing units with a maximum of four families per structure; there are a total of 349 housing units. Many houses have detached garages. Lots are large relative to house size. One store and one church are within the study site, but there are no parks. The water taps are 5/8-inch diameter, service lines are 3/4-inch diameter, and nominal water pressure is 90 pounds per square inch.

The study site water meter is a 6-inchdiameter Badger Compound with two registers. Minimum recordable flow is 0.1 gallon.

Hourly data were collected from October 1963 to September 1965 as part of the Johns Hopkins study (Linaweaver and others, 1966). Miscellaneous measurements were made from 1966 through 1979 . Weekly data were collected from 1980-87 (416 weekly observations); 5 percent of these data are estimates. Hourly data were collected from June 1, 1986, through December 31, 1987 (13,896 hourly observations); 1 percent of these data are estimates.

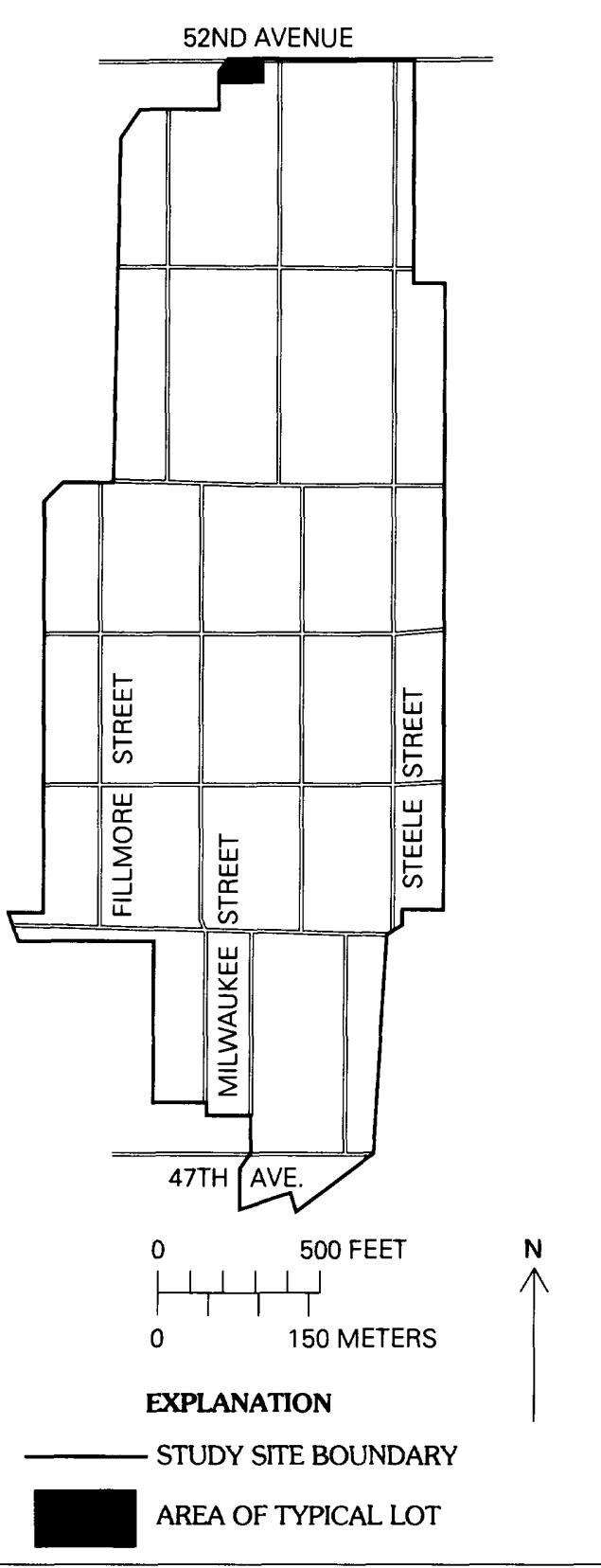




\section{Site N3J (3rd Avenue and Jasmine Street)}

This study site contains mostly large onestory ranches with basements, with some large two-story houses. There are many custom houses and no multifamily houses. Houses were built from 1936 to 1977 . Lots are large with extensive landscaping. No commercial buildings or parks are within the study site. The water taps are a mixture of 5/8-inch diameter and 3/4-inch diameter, service lines are a mixture of 3/4-inch diameter and 1 inch diameter, and nominal water pressure is 100 pounds per square inch.

The study site water meter is a 8-inchdiameter Badger Compound with two registers. Minimum recordable flow is 0.1 gallon.

Hourly data were collected from October 1963 to September 1965 as part of the Johns Hopkins study (Linaweaver and others, 1966). Miscellaneous measurements were made from 1966 through 1979 . Weekly data were collected from 1980-87 (416 weekly observations); 6 percent of these data are estimates. Hourly data were collected from June 1, 1986, through December 31, 1987 (13,896 hourly observations); 1 percent of these data are estimates.

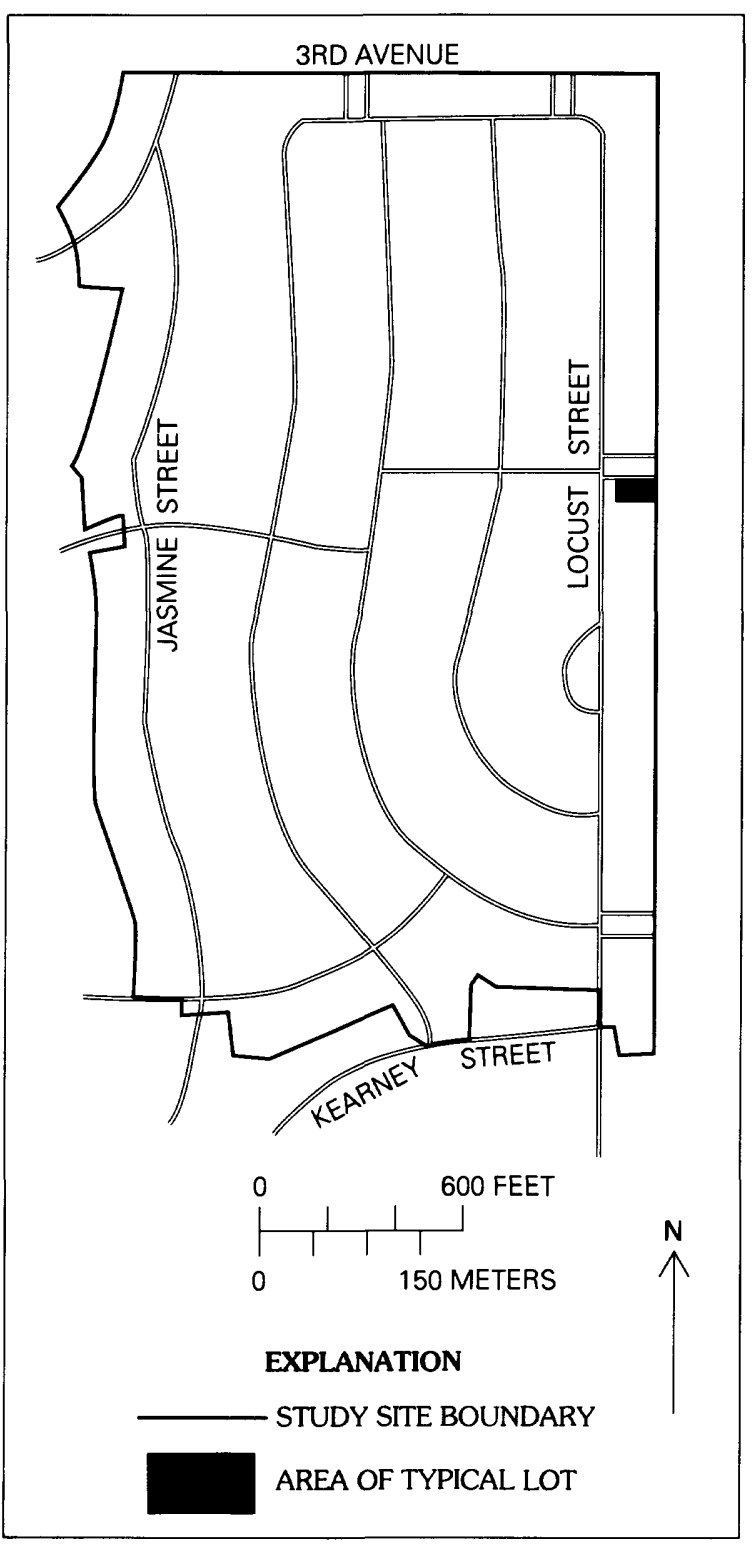




\section{Site N5T (5th Avenue and Tennyson Street)}

This study site contains small one-story houses with basements; most have detached garages. There are 5 two-family houses. The large variety of house models date from 1885 to 1979. No commercial buildings or parks are in this study site. The water taps are a mixture of 5/8-inch diameter and 3/4-inch diameter, the service lines are 3/4-inch diameter, and nominal water pressure is 100 pounds per square inch.

The study site water meter is a 6-inchdiameter Badger Compound with two registers. Minimum recordable flow is 0.05 gallon.

Hourly data were collected from spring 1965 to winter 1966 as part of the Johns Hopkins study (Linaweaver and others, 1966). Miscellaneous measurements were made from 1967 through 1979 . Weekly data were collected from 1980-87 (416 weekly observations); 8 percent of these data are estimates. Hourly data were collected from June 1, 1986, through December 31, 1987 (13,896 hourly observations); 8 percent of these data are estimates.

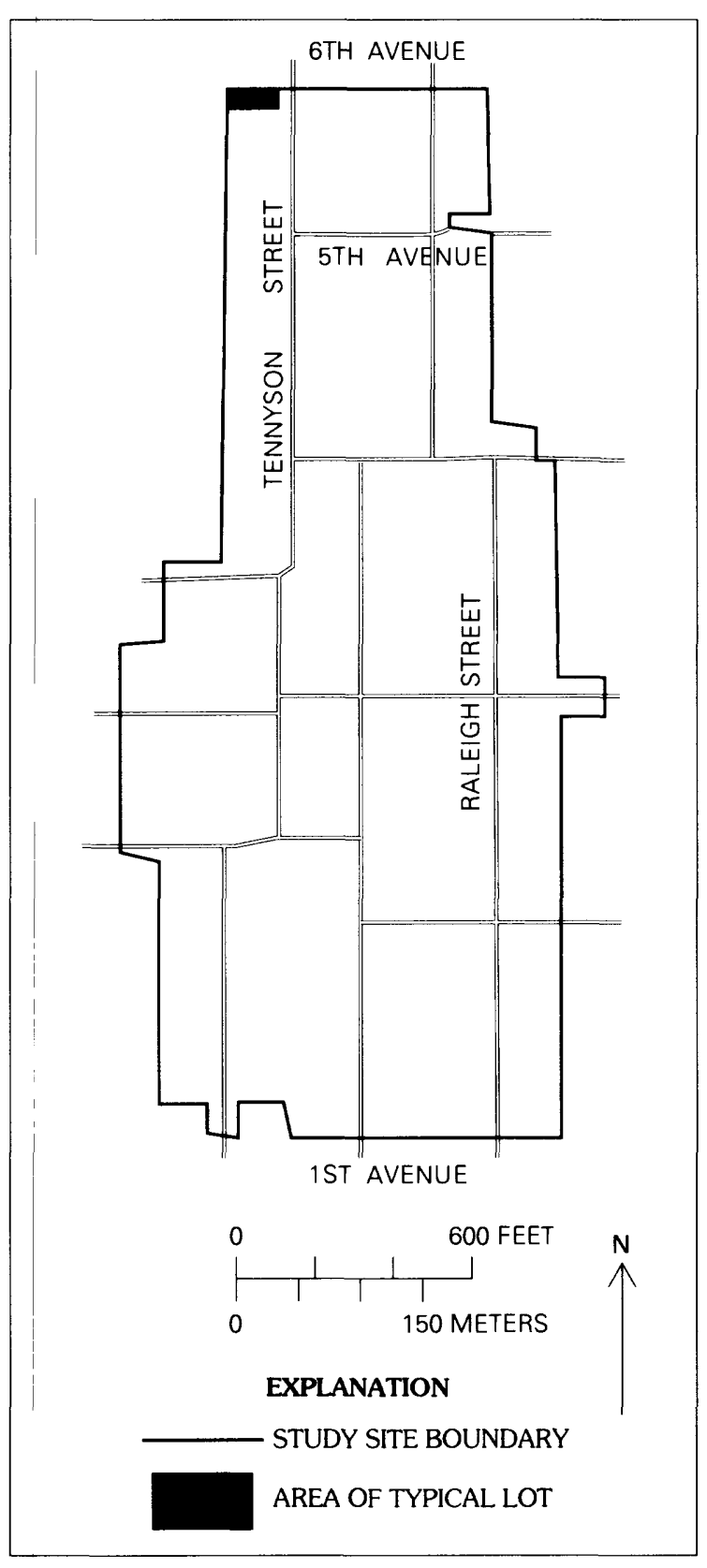




\section{Site N8P (8th Avenue and Pearl Street)}

This study site contains 210 structures and 3,533 housing units; the number of housing units per structure ranges from 1 to 189 . There is a large variety of types of structures, ranging from two-story brick houses to high-rise apartment buildings; all were built from 1876 to 1978. Some commercial buildings and one park are in the study site. Due to the inhomogeneity of this site and a lack of complete information, there was some difficulty in estimating site descriptive variables, and average number of bathrooms and bedrooms per housing unit could not be determined. The water taps are a mixture of 5/8-inch diameter, 3/4-inch diameter, and 1-inch diameter, service lines are a mixture of 3/4-inch diameter and 1-inch diameter, and nominal water pressure is 105 pounds per square inch.

The study site water meter is a 6-inchdiameter Badger Compound with two registers. Minimum recordable flow is 0.05 gallon.

Hourly data were collected from October 1963 to September 1965 as part of the Johns Hopkins study (Linaweaver and others, 1966). Miscellaneous measurements were made from 1967 through 1979 . Weekly data were collected from 1980-87 (416 weekly observations); 6 percent of these data are estimates. Hourly data were collected from June 1, 1986, through December 31, 1987 (13,896 hourly observations); 3 percent of these data are estimates.

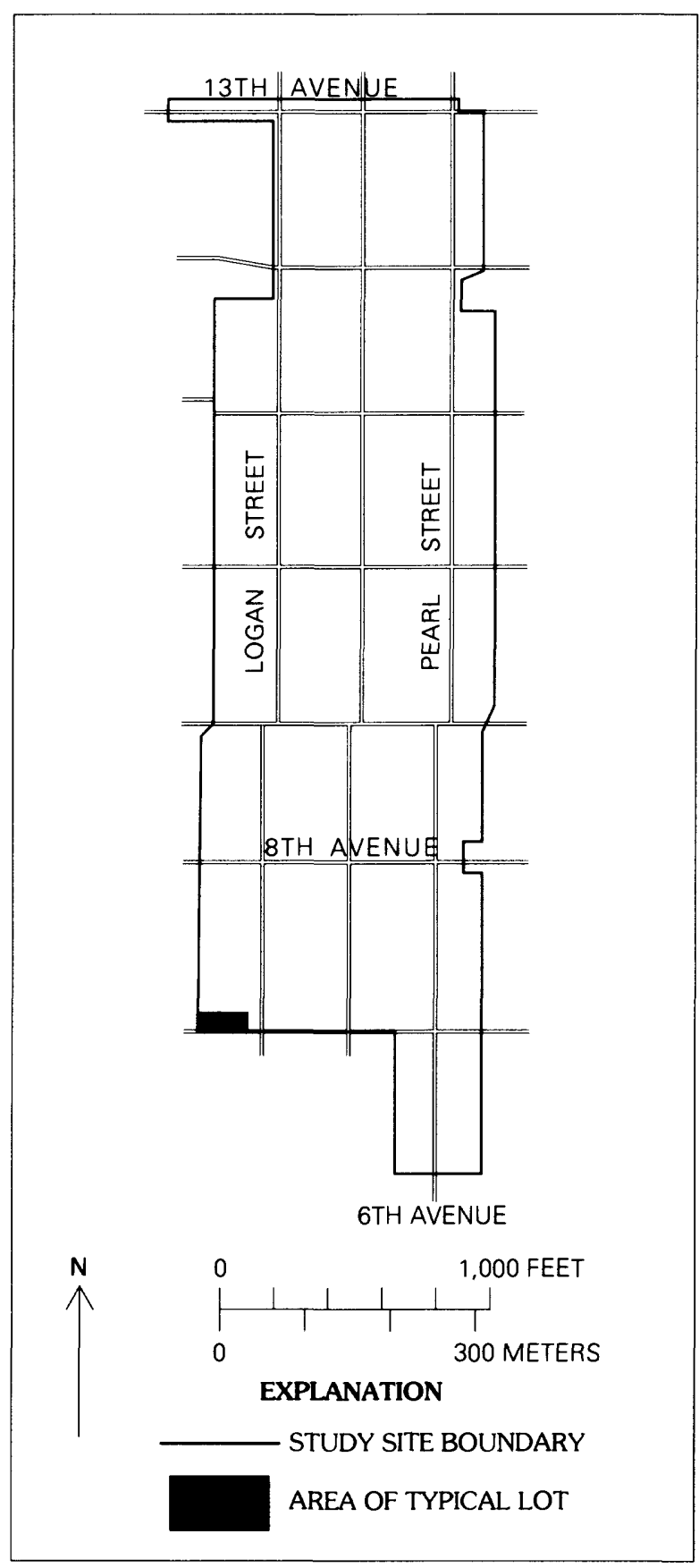




\section{Site NAC (Akron Street and Cornell Avenue)}

This study site contains 329 single-family ranch-style houses and bi-level houses built from 1964 to 1973 . There are no commercial water users, but one city park. The water taps are a mixture of 5/8-inch diameter and 3/4inch diameter, service lines are 3/4-inch diameter, and nominal water pressure is 100 pounds per square inch.

The study site water meter is a 10 - by $6-$ inch diameter Hersey-Sparling with three registers. Minimum recordable flow is 100 gallons.

Miscellaneous data were collected in 1973, 1976, and 1977. Weekly data were collected from 1983-87 (260 weekly observations); 4 percent of these data are estimates. Hourly data were collected from January 1, 1987, through December 31, 1987 (8,832 hourly observations); 17 percent of these data are estimates.

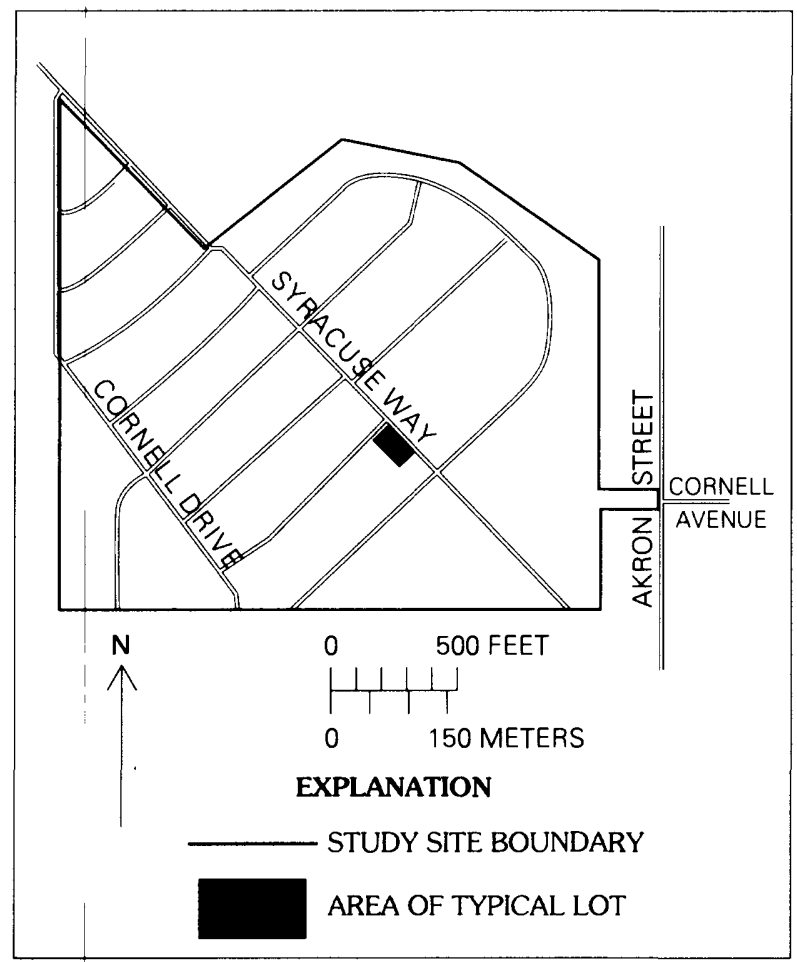




\section{Site NBW (Bates Avenue and Winona Count)}

This study site contains 26 single-family one-story ranch-style houses with basements and garages, all built in 1955 . There are no commercial buildings or parks. This is a paired site with site NDW; the two sites are similar except that houses in site NBW are slightly larger, are on larger lots, and have larger lawns. Houses in site NDW, on the other hand, are somewhat newer and have slightly more bathrooms. The water taps are 5/8-inch diameter, service lines are $3 / 4$-inch diameter, and nominal water pressure is 110 pounds per square inch.

The study site water meter is a 3-inch diameter Hersey with two registers. Minimum recordable flow is 10 gallons.

Weekly data were collected from 1980-87 (416 weekly observations); 6 percent of these data are estimates. Hourly data collected from July 1, 1986, through December 31, 1987 (13,176 hourly observations); 3 percent of these data are estimates.

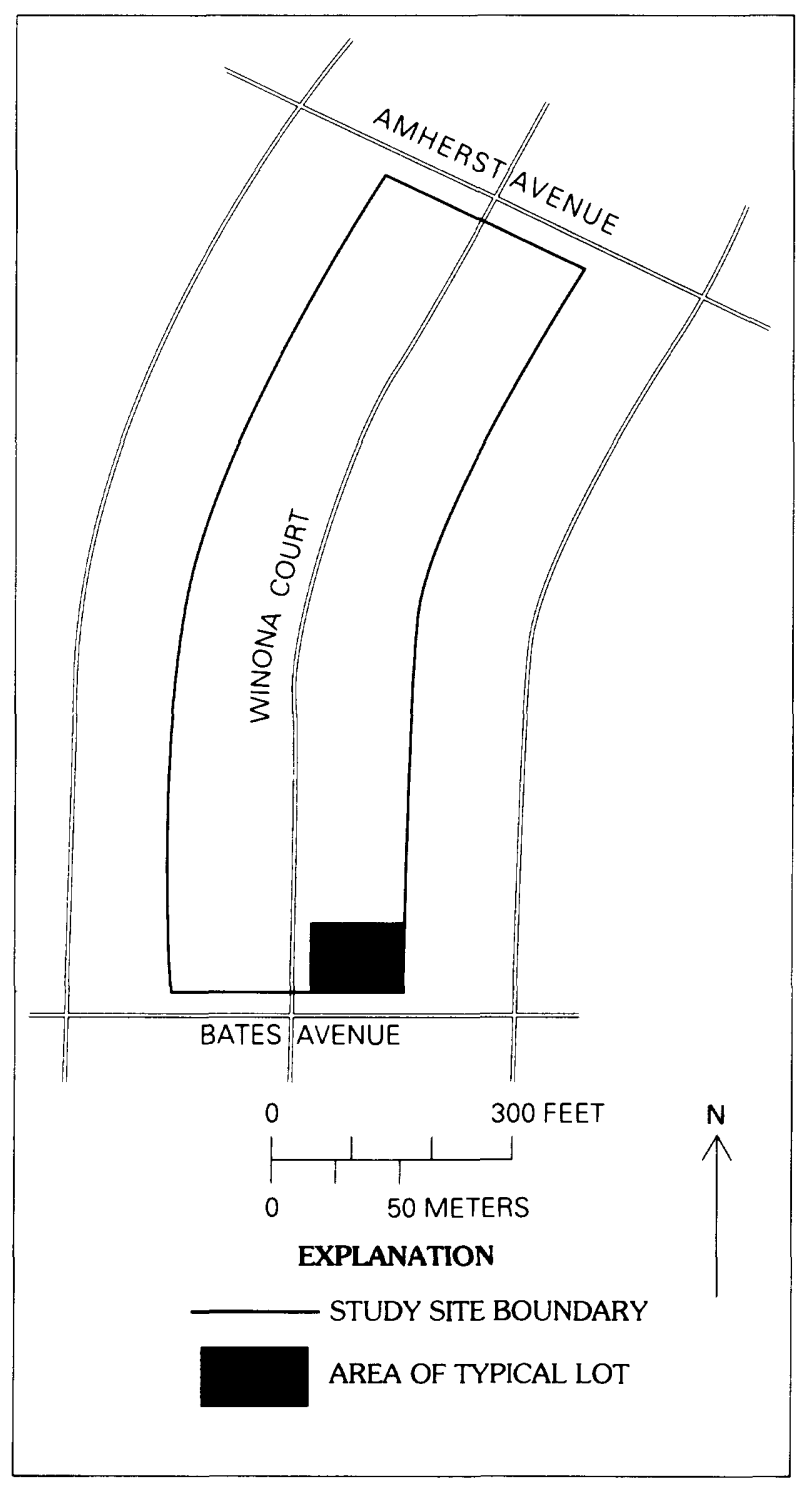




\section{Site NDW (Dantmouth Avenue and Winona Court)}

This study site contains 25 single-family one-story ranch-style houses with basements and garages, all built in 1958. There are no commercial buildings or parks. This is a paired site with site NBW. The water taps are 5/8-inch diameter, service lines are 3/4-inch diameter, and nominal water pressure is 70 pounds per square inch.

The study site water meter is a 3-inch diameter Hersey with two registers. Minimum recordable flow is 10 gallons.

Weekly data were collected from 1986-87 (416 weekly observations); 3 percent of these data are estimates. Hourly data were collected from June 1, 1986, through December 31, 1987 (13,896 hourly observations); 7 percent of these data are estimates.

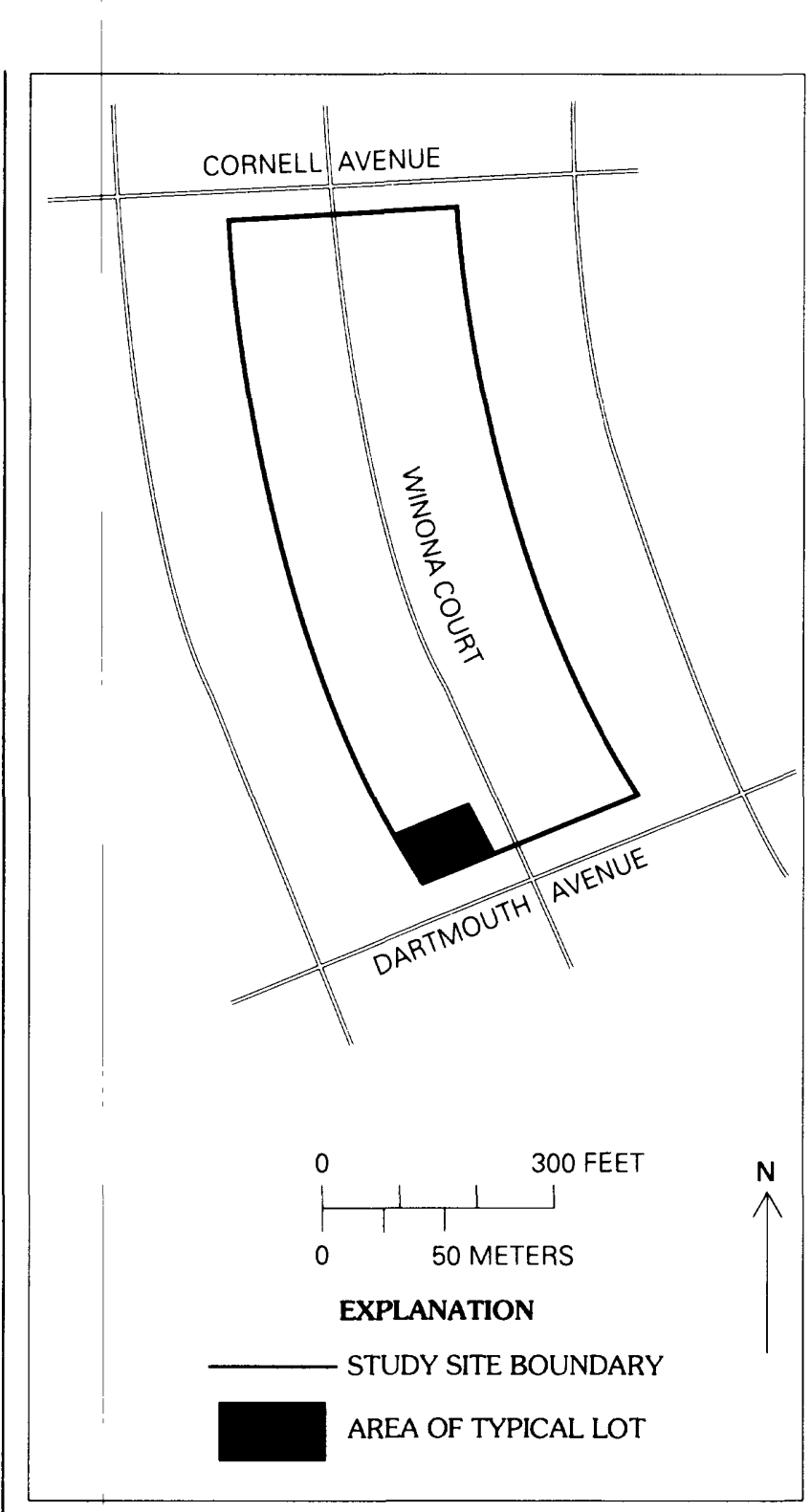


Site NFG (Florida Avenue and Grape Street)

This study site contains 20 single-family small one-story ranch-style houses with carports, all built from 1953 to 1954. There are no commercial buildings or parks. This is a paired site with site NLG; the two sites are similar except that houses in site NFG are slightly larger with more bathrooms and bedrooms, are on larger lots, and have larger lawns. The water taps are $5 / 8$-inch diameter, service lines are 3/4-inch diameter, and nominal water pressure is 90 pounds per square inch.

The study site water meter is a 3-inch diameter Hersey with two registers. Minimum recordable flow is 10 gallons.

Weekly data were collected from 1980-87 (416 weekly observations); 3 percent of these data are estimates. Hourly data were collected from August 1, 1986, through December 31, 1987 (12,432 hourly observations); 15 percent of these data are estimates.

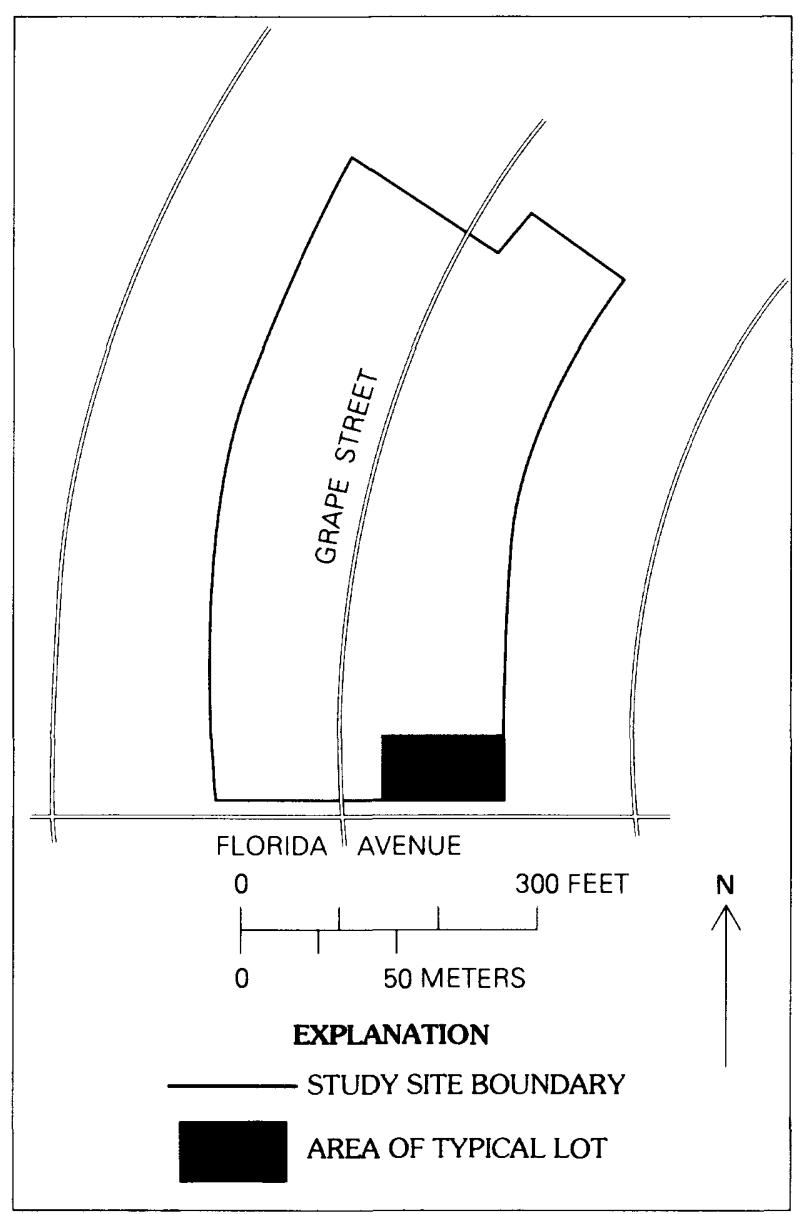




\section{Site NHG (Happy Canyon Road and Glencoe Street)}

This study site contains 22 single-family large one-story ranch-style houses with basements and garages, all built in 1957. There are no commercial buildings or parks. This is a paired site with site NMG; however, houses in site NHG are smaller with fewer bedrooms and bathrooms, and are on smaller lots. Lawn sizes are similar at both sites. The water taps are a mixture of 3/4-inch diameter and 1-inch diameter, service lines are 1-inch diameter, and nominal water pressure is 100 pounds per square inch.

The study site water meter is a 3-inch diameter Hersey with two registers. Minimum recordable flow is 10 gallons.

Weekly data were collected from 1980-87 (416 weekly observations); 4 percent of these data are estimates. Hourly data were collected from September 1, 1986, through December 31, 1987 (11,688 hourly observations); 10 percent of these data are estimates.

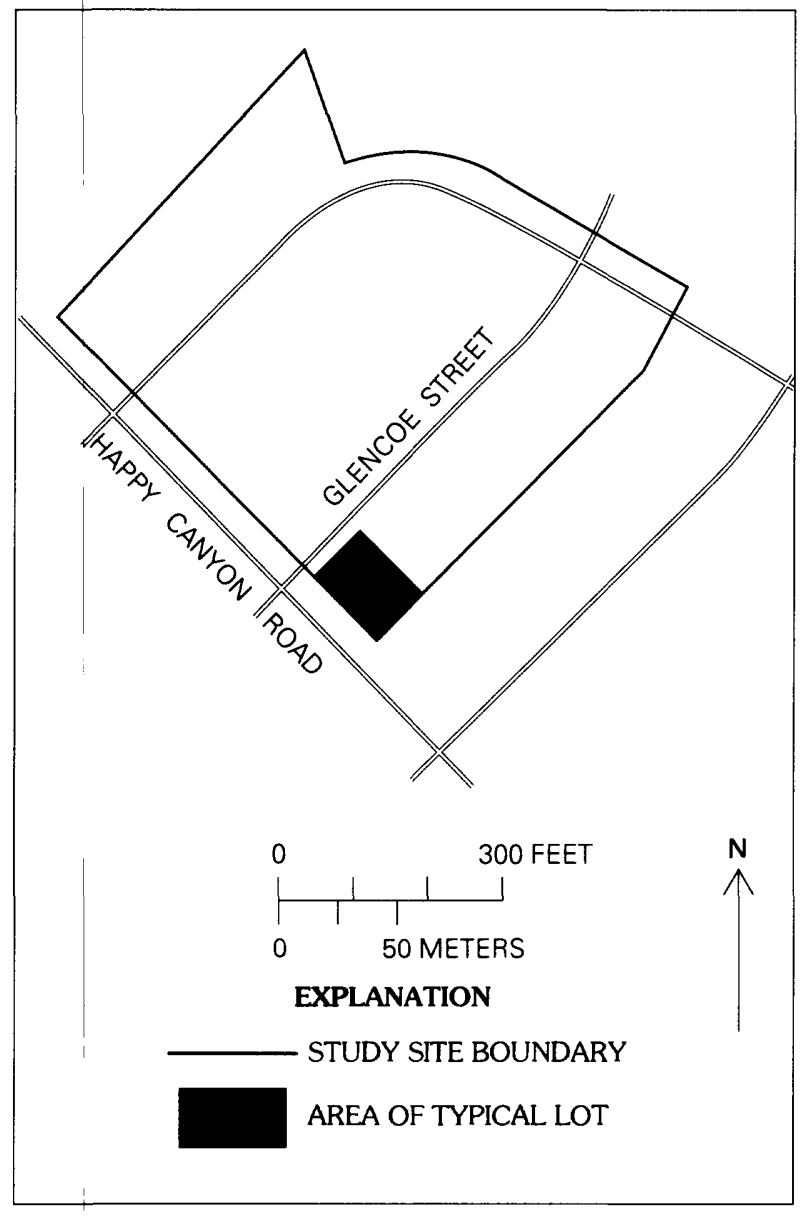


Site NLG (Louisiana Avenue and Grape Street)

This study site contains 22 single-family small one-story ranch-stylehouses with carports, all built from 1953 to 1957 . This is considered a flat-rate billing site, although 3 of the 22 housing units are metered. There are no commercial buildings or parks. This is a paired site with site NFG. The water taps are 5/8-inch diameter, service lines are 3/4-inch diameter, and nominal water pressure is 95 pounds per square inch.

The study site water meter is a 3-inch diameter Hersey with two registers. Minimum recordable flow is 10 gallons.

Weekly data were collected from 1980-87 (416 weekly observations); 3 percent of these data are estimates. Hourly data were collected from August 1, 1986, through December 31, 1987 (12,432 hourly observations); 7 percent of these data are estimates.

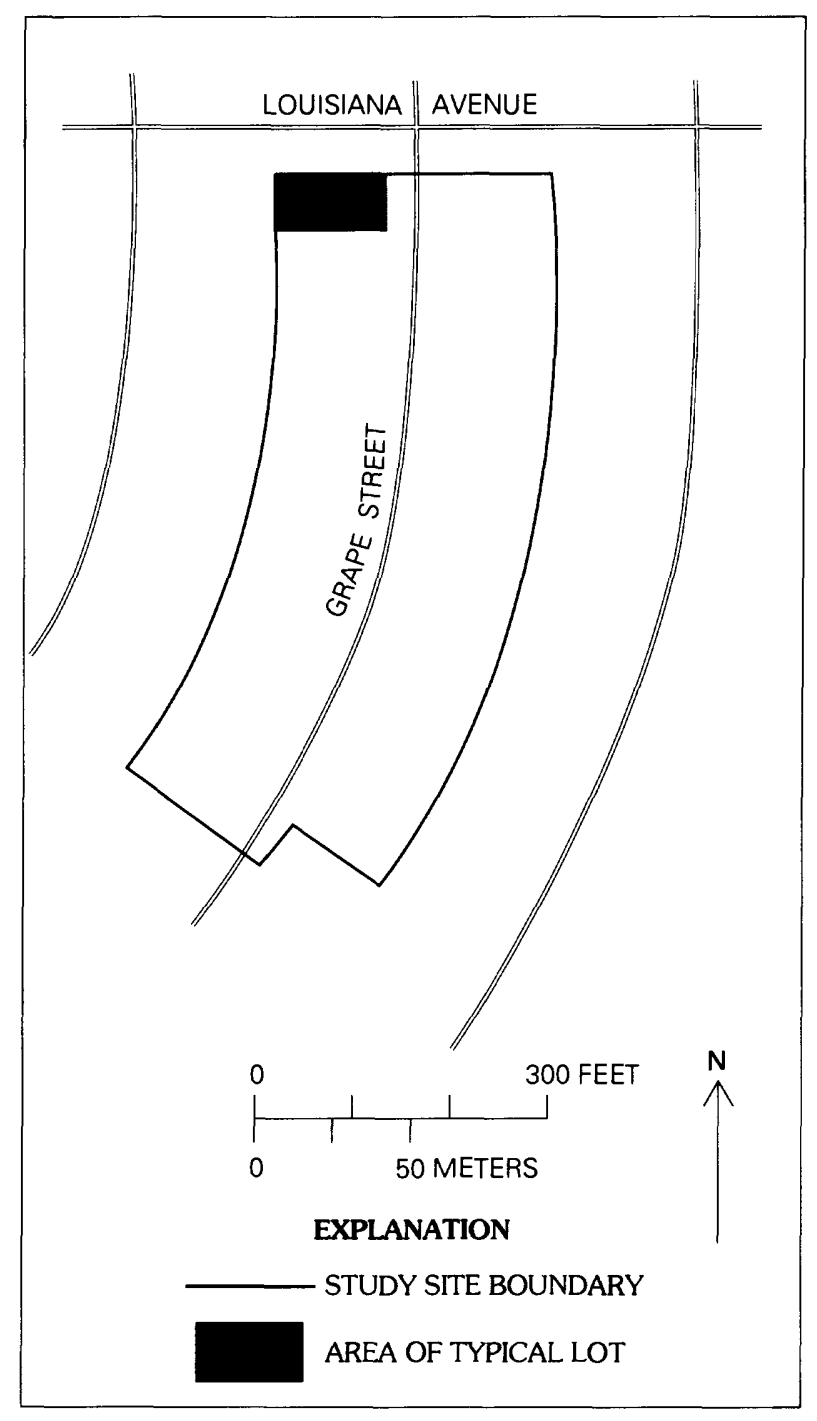




\section{Site NMG (Mansfield Avenue and Grape Street)}

This study site contains 23 single-family large custom ranches built from 1958 to 1962 . Yards are extensively landscaped. There are no commercial buildings or parks. This is a paired site with site NHG. The water taps are $3 / 4$-inch diameter, service lines are 1-inch diameter, and nominal water pressure is 90 pounds per square inch.

The study site water meter is a 3-inch diameter Hersey with two registers. Minimum recordable flow is 10 gallons.

Weekly data were collected from 1980-87 of these data are estimates. Hourly data were collected from June 1, 1986, through December 31,1987 ( 13,896 hourly observations); 4 percent of these data are estimates. (416 weekly observations); less than 1 percent

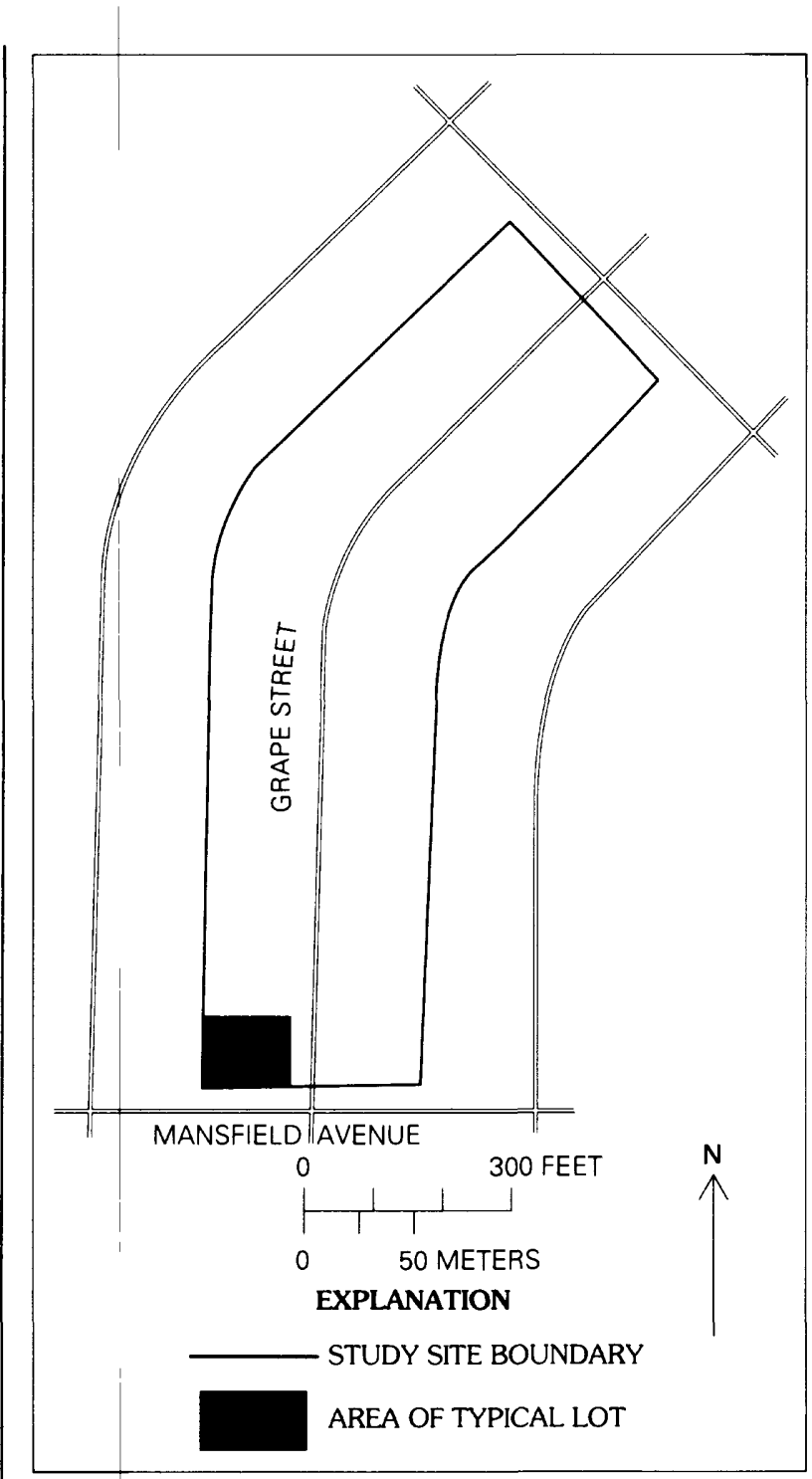


Site NYH CYosemite Street and Highline Canal)

This study site contains 24 12-unit townhouses, built from 1979 to 1981 . Of the 280 units, 261 were occupied during the study. The units are two-story houses with adjoining garages and storage areas. The townhouse complex includes landscaped areas, tennis courts, and a recreation center. The water taps are 1-inch diameter, service lines are 1-inch diameter, and nominal water pressure is 120 pounds per square inch.

The study site water meter is a 10- by $6-$ inch diameter Hersey-Sparling with three registers. Minimum recordable flow is $\mathbf{1 1 0}$ gallons.

Weekly data were collected from 1983-87 (260 weekly observations); less than 1 percent of these data are estimates. Hourly data were collected from January 1, 1987, through December 31,1987 (8,832 hourly observations); 3 percent of these data are estimates.

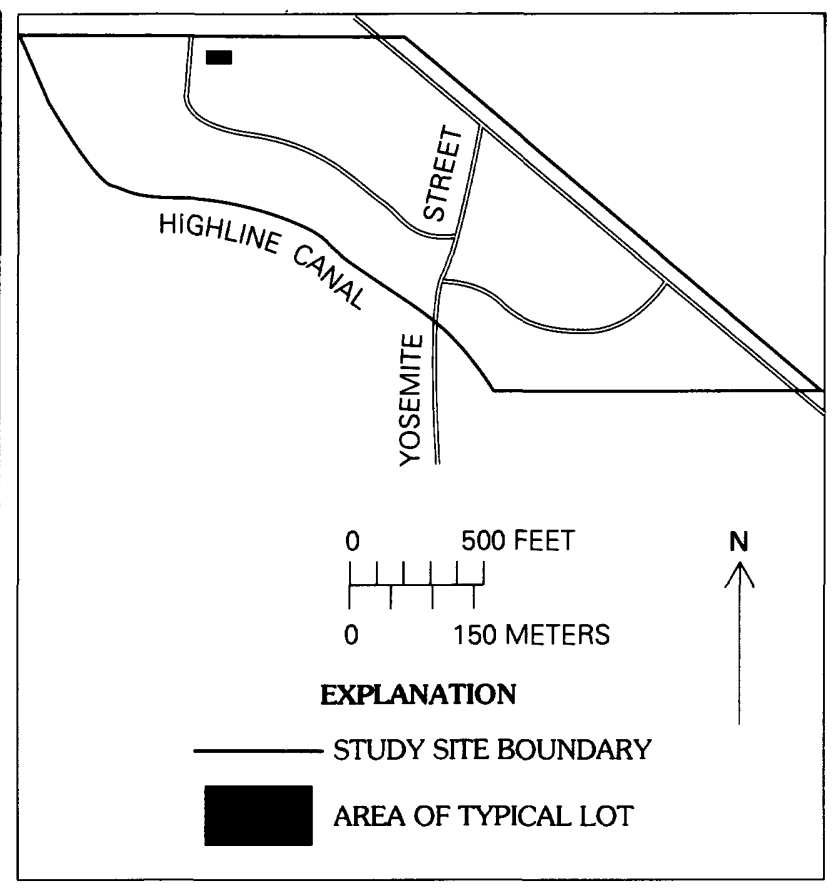




\section{DESCRIPTION OF DATA FILES ON DISK}

The dataset used for this study is available on computer floppy disk from the U.S. Geological Survey and the Denver Water Department at the following addresses:

$$
\begin{aligned}
& \text { U.S. Geological Survey } \\
& \text { Box 25046, Mail Stop } 415 \\
& \text { Federal Center } \\
& \text { Denver, CO 80225-0046 }
\end{aligned}
$$

Denver Water Department 1600 West 12th Avenue

Denver, CO 80204

There are three files on this disk:

\section{File 1--Site descriptive variables:}

This file consists of 14 variables and 16 fields (one for each study site). The variables are the descriptive variables listed in table 1 plus the water use summary statistics listed in table 2 .

File 2--Weekly dataset:

This file consists of 416 observations of average weekly water use (1980-87) for the 16 study sites. A code field is present for each site to distinguish estimated data. Also present in this file are average maximum temperature for each week and total rainfall for the week.

\section{File 3--Hourly dataset:}

This file consists of a maximum of 512 days of data for each site, with 24 hourly use rates for each day. A code field is present to indicate if data are estimated. 


\section{DESIGN GRAPHS}




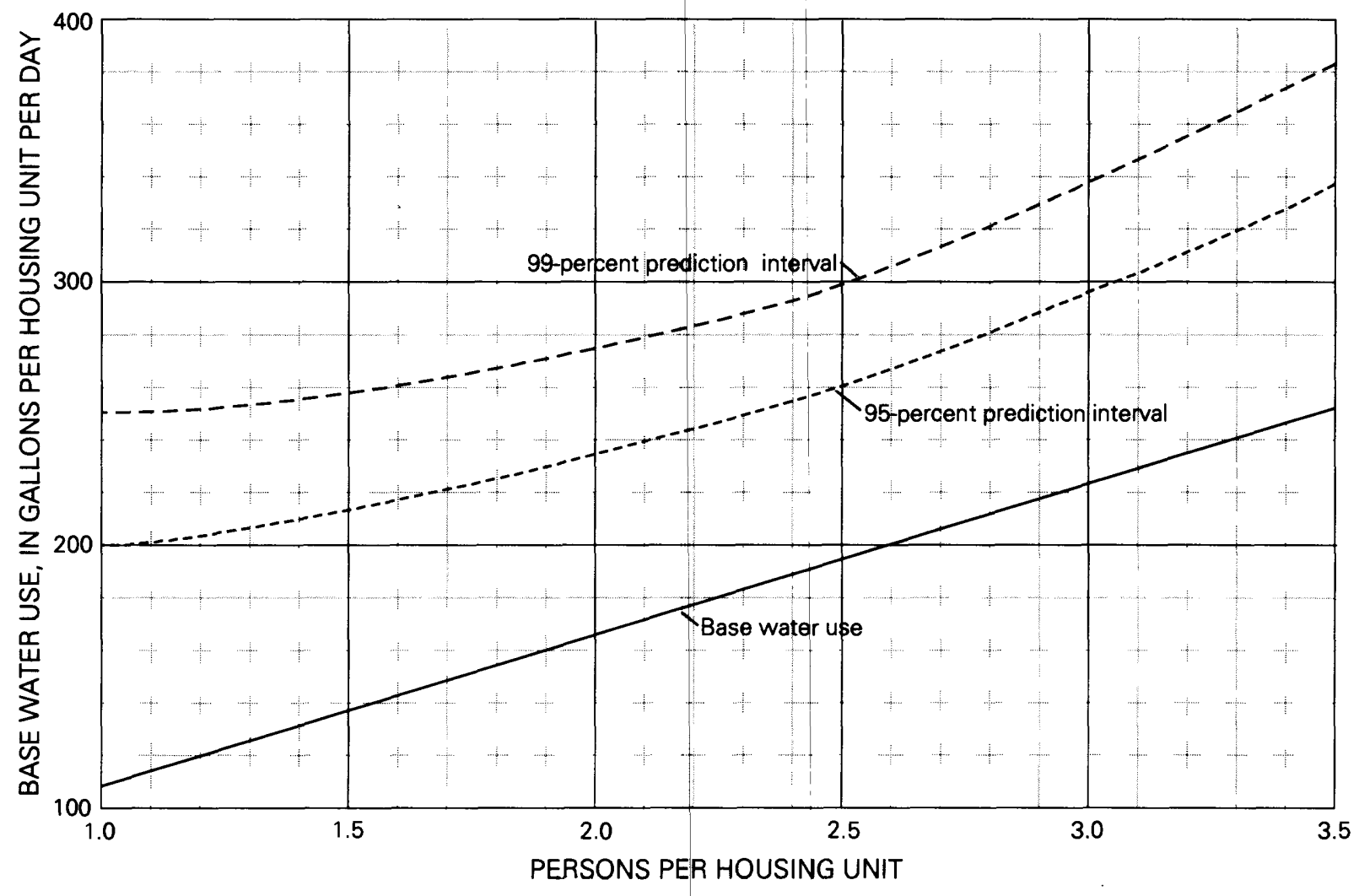

Design Graph A.--Base water use, metered sites 


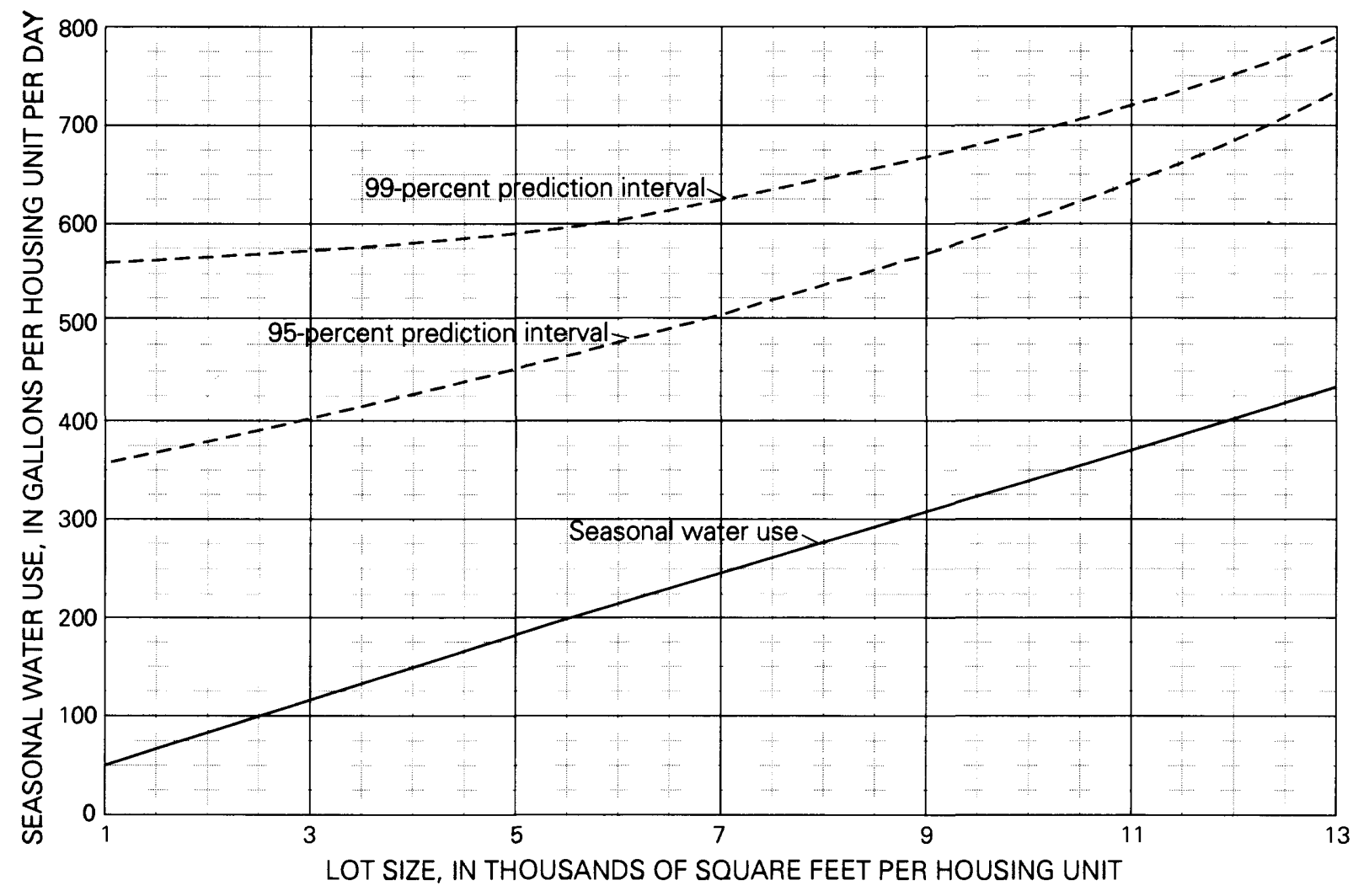

Design Graph B.--Seasonal water use, metered sites 


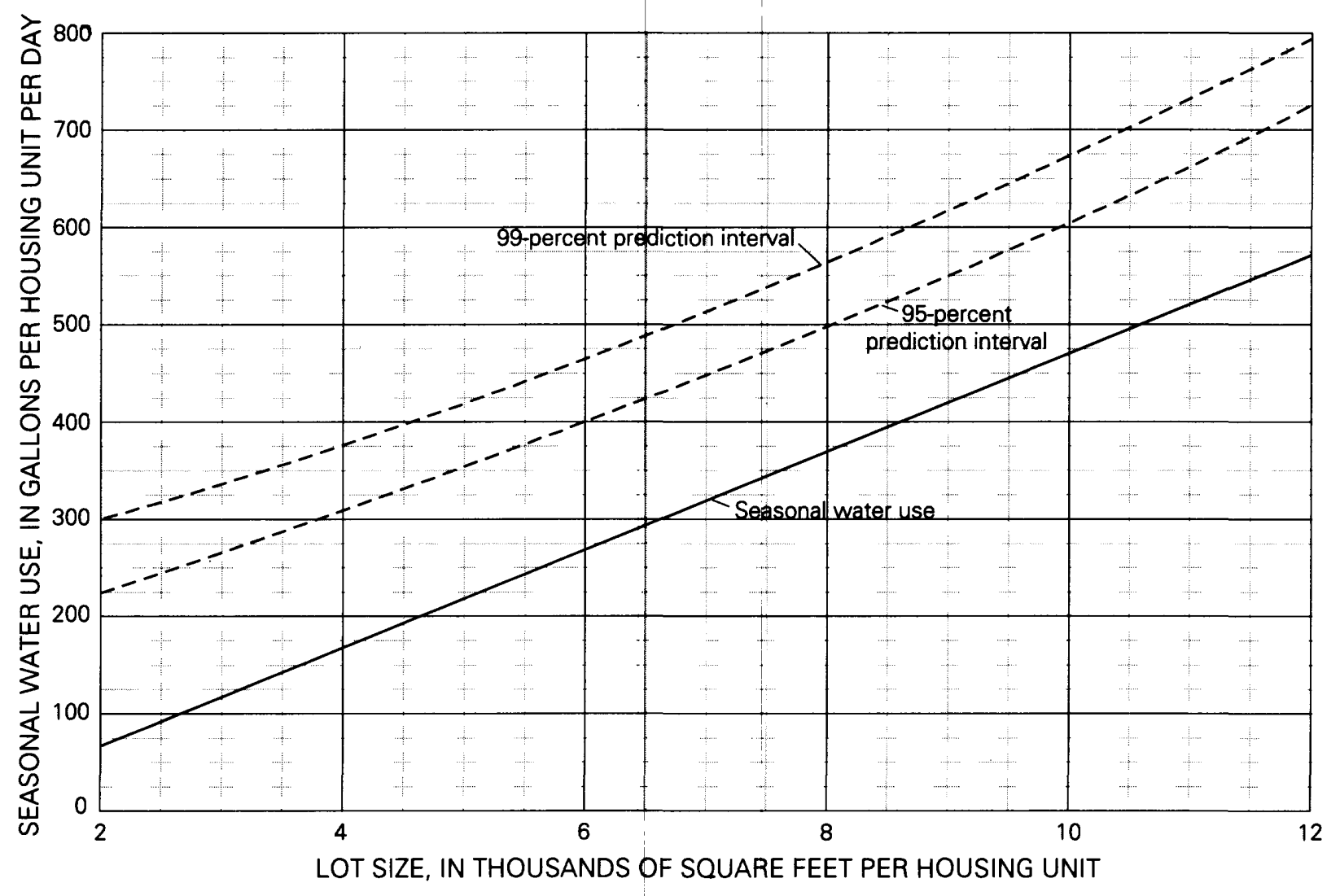

Design Graph C.--Seasonal water use, flat-rate sites 


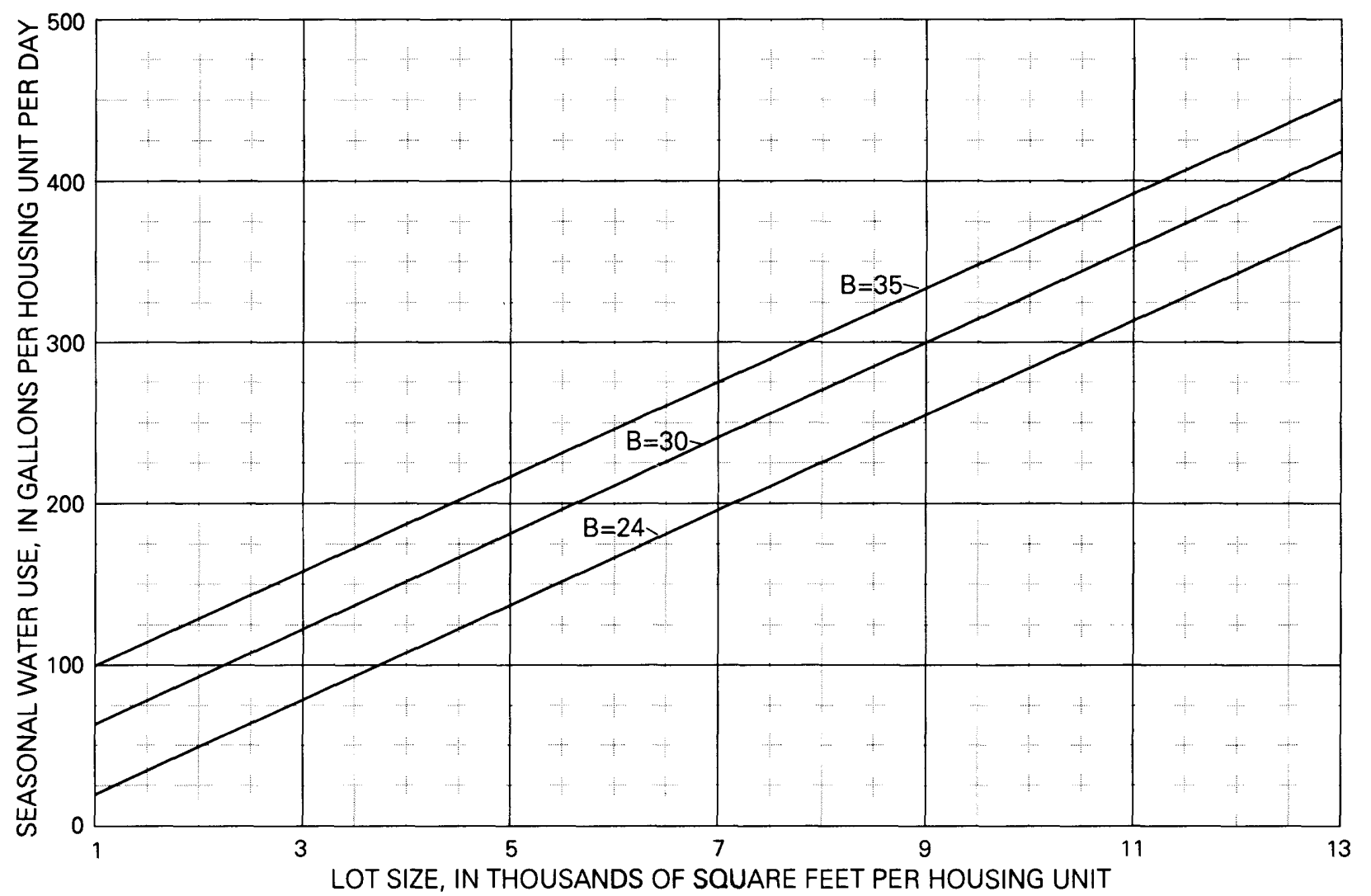

Design Graph D.--Seasonal water use using Blaney-Criddle water requirement, in inches (B), metered sites: predicted value. 


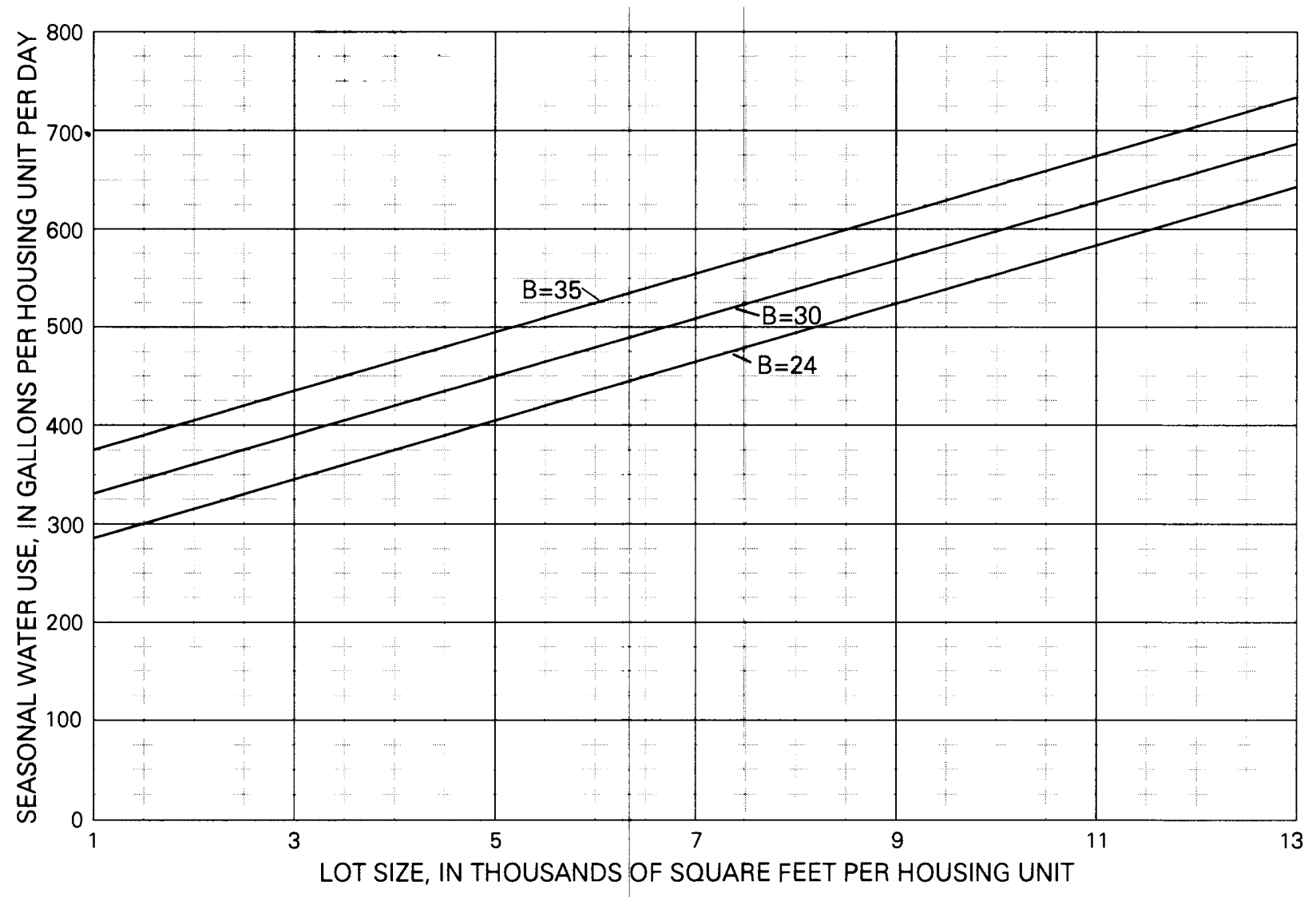

Design Graph E.--Seasonal water use using Blaney-Criddle water requirement, in inches (B), metered sites: 99-percent prediction interval. 


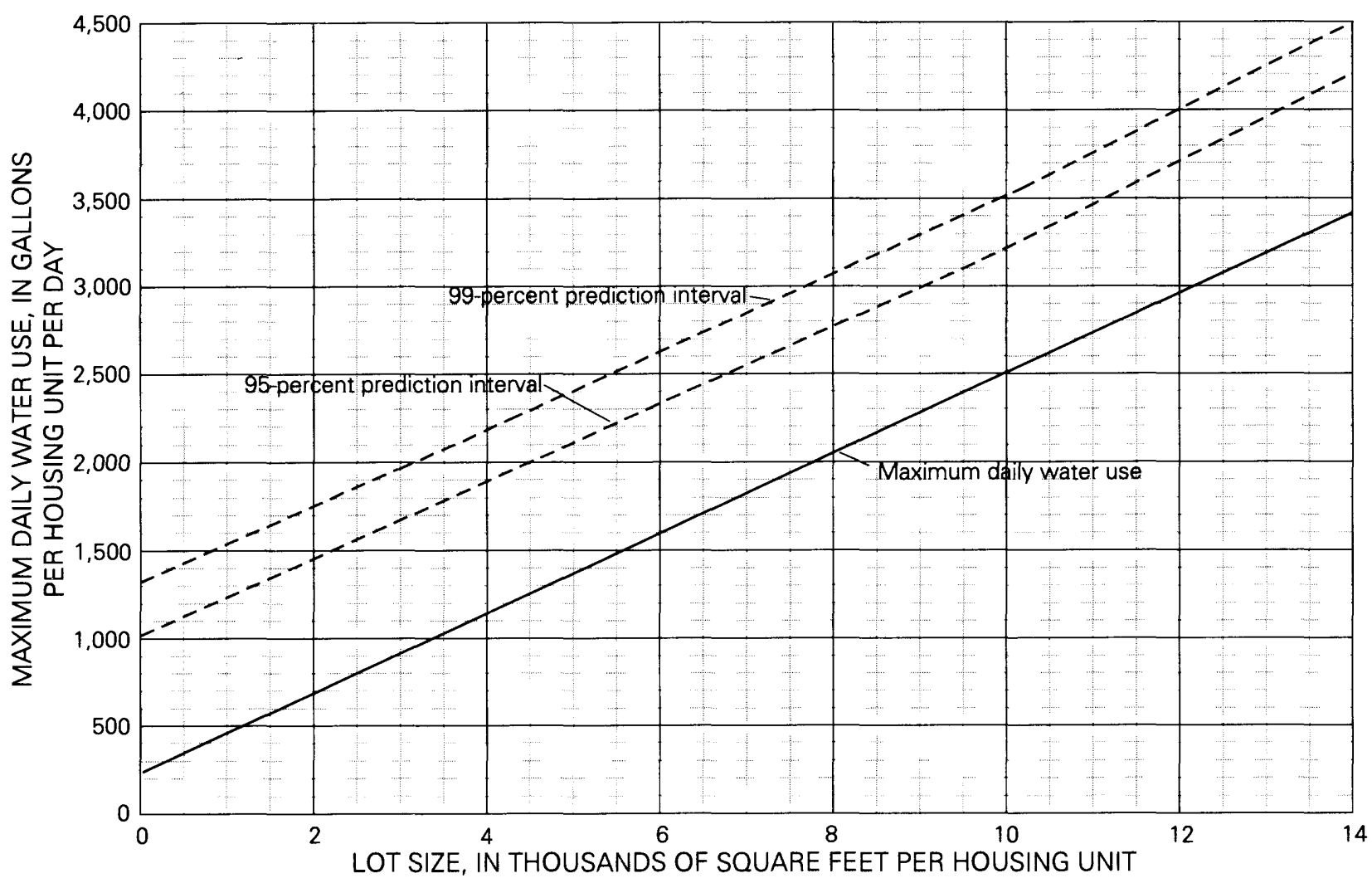

Design Graph F.--Maximum daily water use. 


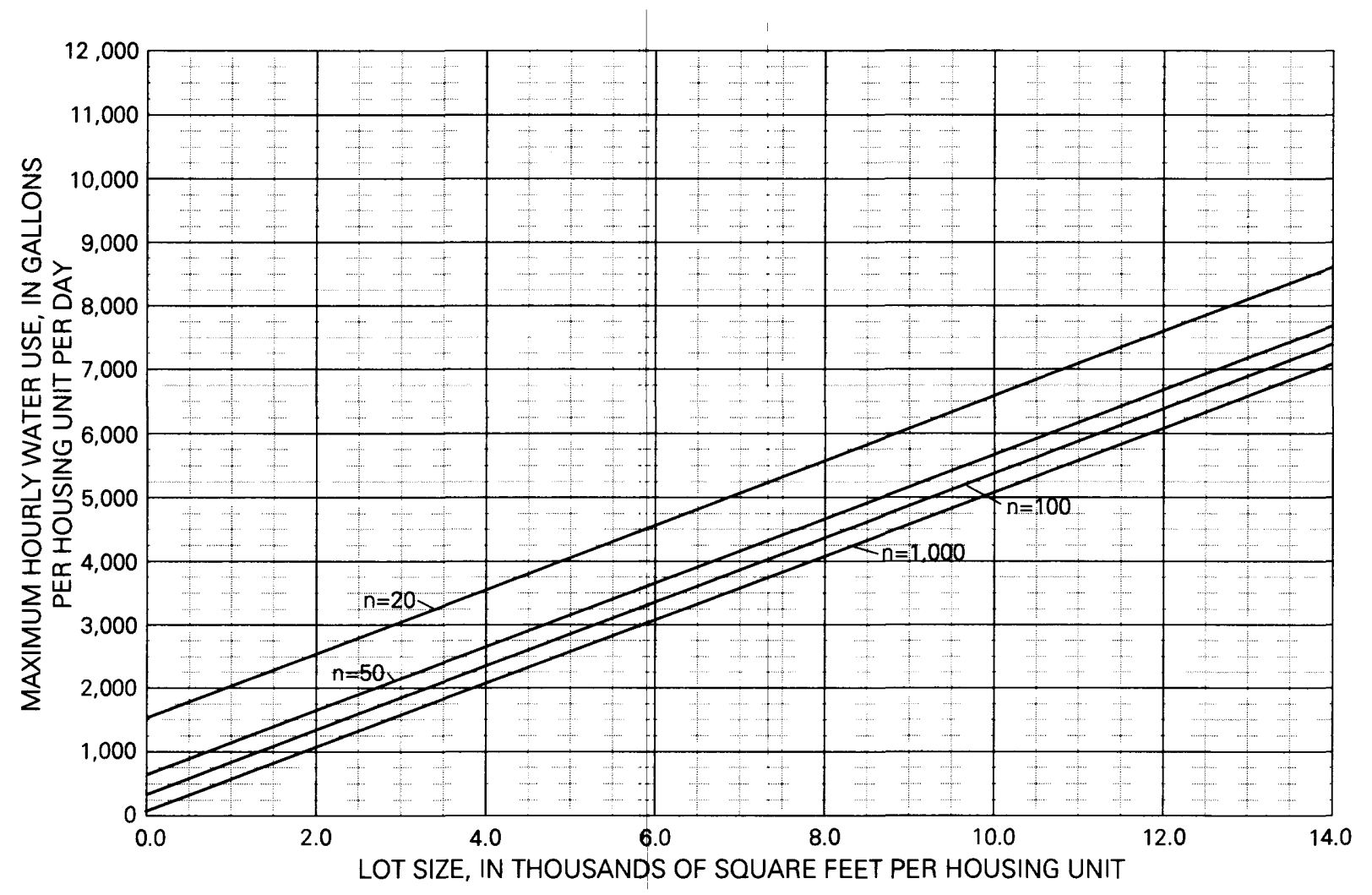

Design Graph G.--Maximum hourly water use using number of housing units (n): predicted value. 


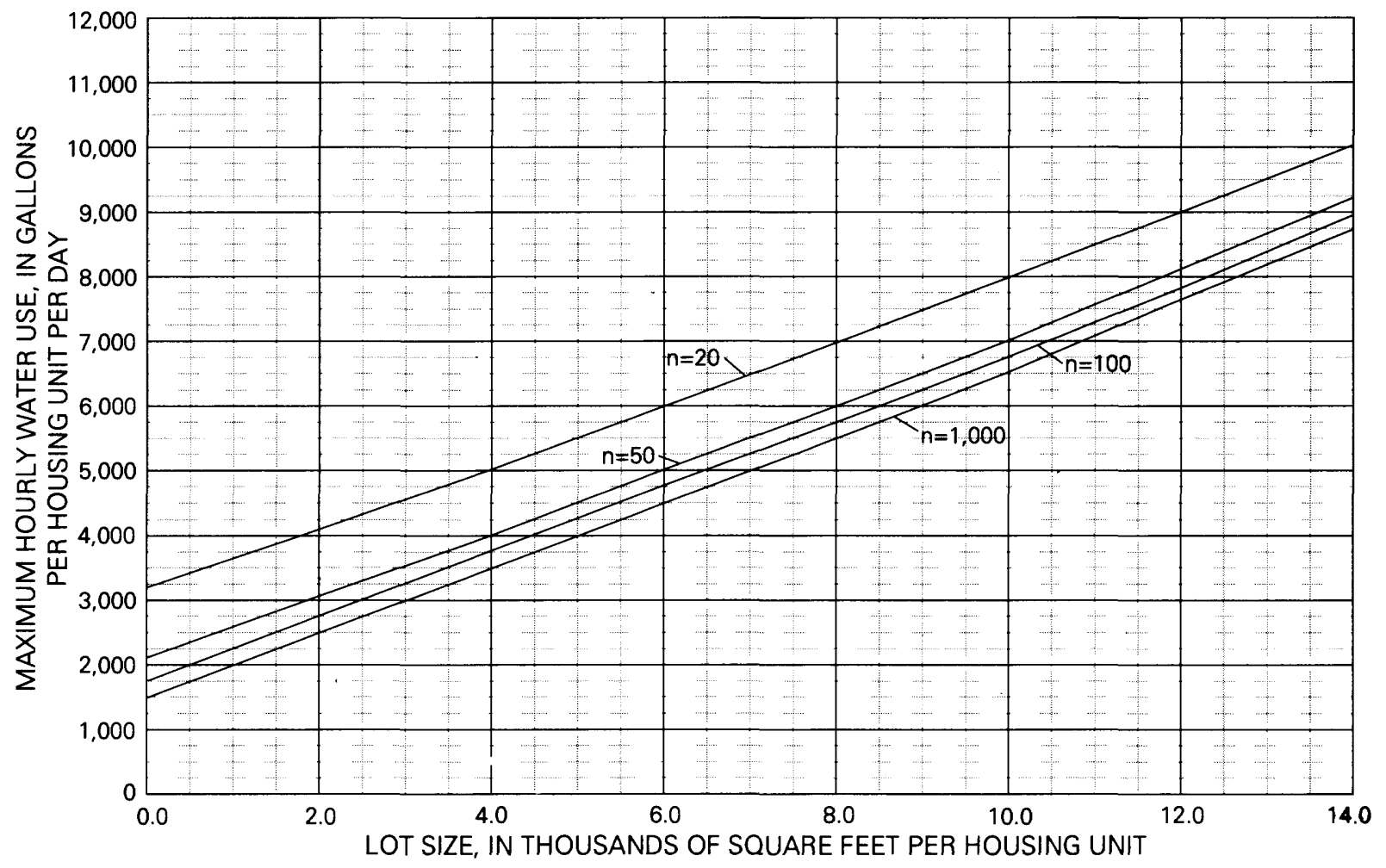

Design Graph H.--Maximum hourly water use using number of housing units (n): 99-percent prediction interval. 